\title{
The Use of Electromyogram (EMG) Telemetry to Assess Swimming Activity and Energy Use of Adult Spring Chinook Salmon Migrating through the Tailraces, Fishways, and Forebays of Bonneville Dam, 2000 and 2001
}

R.S. Brown and D.R. Geist

(Pacific Northwest National Laboratory)

M.G. Mesa

(U.S. Geological Survey Biological Resources Division)

September 2002

Prepared for

the U.S. Army Corps of Engineers

Portland District, Portland, Oregon

under Contract DE-AC06 76RLO1830

CENWP MIPR No. W66QK10432368 


\title{
DISCLAIMER
}

This report was prepared as an account of work sponsored by an agency of the United States Government. Neither the United States Government nor any agency thereof, nor Battelle Memorial Institute, nor any of their employees, makes any warranty, express or implied, or assumes any legal liability or responsibility for the accuracy, completeness, or usefulness of any information, apparatus, product, or process disclosed, or represents that its use would not infringe privately owned rights. Reference herein to any specific commercial product, process, or service by trade name, trademark, manufacturer, or otherwise does not necessarily constitute or imply its endorsement, recommendation, or favoring by the United States Government or any agency thereof, or Battelle Memorial Institute. The views and opinions of authors expressed herein do not necessarily state or reflect those of the United States Government or any agency thereof.

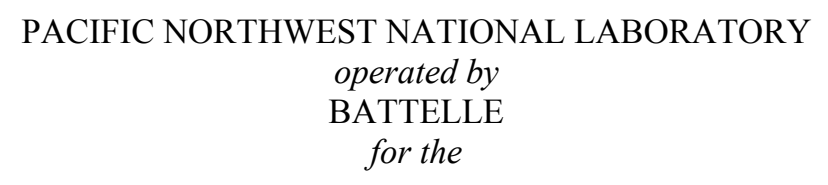

UNITED STATES DEPARTMENT OF ENERGY

under Contract DE-AC06-76RL01830

Printed in the United States of America

\author{
Available to DOE and DOE contractors from the \\ Office of Scientific and Technical Information, \\ P.O. Box 62, Oak Ridge, TN 37831-0062; \\ ph: (865) 576-8401 \\ fax: (865) 576-5728 \\ email: reports@adonis.osti.gov
}

Available to the public from the National Technical Information Service, U.S. Department of Commerce, 5285 Port Royal Rd., Springfield, VA 22161 ph: (800) 553-6847 fax: (703) 605-6900

email: orders@ntis.fedworld.gov online ordering: http://www.ntis.gov/ordering.htm 


\title{
The Use of Electromyogram (EMG) Telemetry to Assess Swimming Activity and Energy Use of Adult Spring Chinook Salmon Migrating through the Tailraces, Fishways, and Forebays of Bonneville Dam, 2000 and 2001
}

\author{
R.S. Brown \\ D.R. Geist \\ M.G. Mesa
}

September 2002

Prepared for

the U.S. Army Corps of Engineers

Portland District, Portland, Oregon

under Contract DE-AC06 76RLO1830

CENWP MIPR No. W66QK10432368

PNNL-14080

Prepared by

Pacific Northwest National Laboratory

P.O. Box 999

Richland, WA 99352

U.S. Geological Survey

Biological Resources Discipline

Western Fisheries Research Center

Columbia River Research Laboratory

5501-A Cook-Underwood Road

Cook, WA 98605 



\section{Summary}

In 2000, the Pacific Northwest National Laboratory (PNNL) and the U.S. Geological Survey (USGS) initiated a two-year study for the U.S. Army Corps of Engineers to investigate the metabolic rate and swimming performance and to estimate the total energy used (i.e., aerobic and anaerobic) by adult spring chinook salmon (Oncorhynchus tshawystcha) migrating upstream through a large hydropower dam on the Columbia River. The investigation involved one year of laboratory study and one year of field study at Bonneville Dam.

The objectives of the laboratory study were to 1) measure active rates of oxygen consumption of adult spring chinook salmon at three water temperatures over a range of swimming speeds; 2) estimate the upper critical swimming speed (Ucrit) of adult spring chinook salmon; and 3) monitor electromyograms (EMGs) of red and white muscle in the salmon over a range of swimming speeds.

The objectives of the field study were to estimate the energetic costs incurred by salmon as they passed the tailraces, fishways, and forebays of Bonneville Dam. In addition we sought specifically to estimate and compare the swimming speeds and energetic costs of salmon as they passed through different sections of the dam's fishways.

Laboratory study results indicated that the rate of oxygen consumption and red and white muscle activity in adult spring chinook salmon were strongly correlated with swimming speed over a range of fish sizes and at three different temperatures. Active oxygen consumption $\left(\mathrm{VO}_{2}\right)$ increased linearly with swim speed before leveling off at speeds at or above Ucrit. This pattern was similar at each water temperature and indicated that fish were approaching their maximal aerobic oxygen consumption at higher swim speeds. Modeling showed that temperature, but not size or sex, influenced the relation between $\mathrm{VO}_{2}$ and swim speed, thus a $\mathrm{VO}_{2}$-swim speed model based on temperature (but independent of sex and size) should be a biologically relevant way of estimating the energy use of fish in the wild.

In the field studies at Bonneville Dam, EMG radiotelemetry was used to examine the amount of energy spring chinook salmon expend while migrating upstream past the dam's tailraces, fishways, and forebays. Electromyogram transmitters were surgically implanted in the red muscle of the fish and calibrated to swim speeds for each fish prior to release. The fish were released below Bonneville Dam and tracked on 19 underwater and surface receivers through the dam's tailrace, fishways, and forebays.

Aerobic and anaerobic energy use rates were determined. The rates of energy used (i.e., kilo calories per kilogram per hour $\left[\mathrm{kcal} \mathrm{kg}^{-1} \mathrm{~h}^{-1}\right]$ ) by spring chinook salmon were significantly higher in the tailraces $\left(2.80 \mathrm{kcal} \mathrm{kg}^{-1} \mathrm{~h}^{-1}\right)$ than in other parts of the dam, e.g., $26 \%$ higher than rates for the fishways $(2.22 \mathrm{kcal}$ $\mathrm{kg}^{-1} \mathrm{~h}^{-1}$ ) and $62 \%$ higher than for the forebays $\left(1.73 \mathrm{kcal} \mathrm{kg}^{-1} \mathrm{~h}^{-1}\right)$. Most of the energy used (i.e., $\mathrm{kcal} \mathrm{kg}^{-1}$ ) by the fish was expended in the tailraces: $81 \%$ of the median energy used was expended in the tailrace $\left(48.1 \mathrm{kcal} \mathrm{kg}^{-1}\right)$, while only $18 \%\left(11.1 \mathrm{kcal} \mathrm{kg}^{-1}\right)$ and $1.5 \%\left(0.9 \mathrm{kcal} \mathrm{kg}^{-1}\right)$ were used in the fishways and forebays, respectively. A portion of the fish (the $90^{\text {th }}$ percentile) used up much more energy passing these areas; e.g., $\sim 300 \mathrm{kcal} \mathrm{kg}^{-1}$ to pass the tailraces; $50 \mathrm{kcal} \mathrm{kg}^{-1}$ to pass the forebays, and $\sim 40 \mathrm{kcal} \mathrm{kg}^{-1}$ to pass the fishways.

Among all fishway areas, Cascade Island fishway appears to be more energetically costly than other fishways. Also, section 12 of the Washington shore fishway appears costly. This is likely due to the diversion of fish to the Adult Facility, which occurs in this section. It appears from our data that there is an energetic cost associated with diverting fish from the Washington shore ladder to the adult facility. 
Energy used during fallouts was substantial (11.5\% to $18.8 \%$ of the amount of energy used for successful fishway passages). This percentage was highest in the Cascade Island fishway (18.8\%) where energy use rates during fallout were even higher $\left(3.67 \mathrm{kcal} \mathrm{kg}^{1} \mathrm{~h}^{1}\right)$ than energy use rates in the tailrace $\left(2.8 \mathrm{kcal} \mathrm{kg}^{1} \mathrm{~h}^{1}\right)$. 


\section{Acknowledgments}

Funding for this study was provided by the U.S. Army Corps of Engineers (USCOE) through the Anadromous Fish Evaluation Program. Michael Langeslay and David Clugston were the technical contracting officers from the USCOE.

We would like to thank Scott Abernethy, Jessica Carter, Traci Degerman, Karen Dunmall, and Ian Welch of the Pacific Northwest National Laboratory for their field assistance and scientific advice. We wish to thank Israel Duran, Mike Gough, Jon Martin, Ann Postera, Sarah Rose, Chris Schafer, and Lisa Weiland of the U.S. Geological Survey Biological Resources Division for their field assistance. We would also like to thank Tammy Mackey of USCOE and Chuck Boggs, Megan Heinrich, Steve Lee, Chris Peery and Ken Tolotti of the University of Idaho for their assistance. Thank you to C. McKinstry and V. Cullinan of PNNL for statistical support. And thank you to the personnel at the Carson and Little White Salmon National Fish Hatcheries for providing fish for this study. 


\section{Contents}

Summary

Acknowledgments $\quad$ v

$\begin{array}{lll}1.0 & \text { Introduction } & 1.1\end{array}$

1.1 Objectives 1.1

$\begin{array}{lll}1.2 & \text { Background } & 1.1\end{array}$

$\begin{array}{lll}1.3 & \text { Study Area } & 1.3\end{array}$

$\begin{array}{lll}\text { 1.3.1 } & \text { Bradford Island Fish Ladder } & 1.4\end{array}$

1.3.2 Cascade Island Fish Ladder $\quad 1.7$

1.3.3 Washington Shore Fish Ladder 1.7

2.0 Methods $\quad 2.1$

$2.1 \quad$ Laboratory Studies $\quad 2.1$

2.1.1 Fish Collection and Holding 2.1

2.1.2 Respirometry Trials 2.1

2.1.3 Critical Swimming Speed Trials 2.4

2.1.4 Electromyogram Swim Speed Trials 2.4

$2.2 \quad$ Field Studies $\quad 2.6$

2.2.1 Fish Collection and Tagging 2.6

2.2.2 Calibration of EMG Signals to Swim Speed 2.7

2.2.3 EMG Signal Tracking 2.8

2.2.4 Determination of Energy Use Rates 2.11

2.2.5 Radio Tagging and Determination of Location in Fishways 2.12

$\begin{array}{lll}3.0 & \text { Results } & 3.1\end{array}$

$3.1 \quad$ Laboratory Results $\quad 3.1$

3.1.1 Respirometry Trials $\quad 3.1$

3.1.2 Critical Swimming Speed $\quad 3.2$

3.1.3 Electromyogram-Swim Speed Relations $\quad 3.3$

$3.2 \quad$ Field Study Results 3.6

3.2.1 Comparisons between Tailraces, Fishways, and Forebays 3.6

3.2.2 Comparisons within Tailraces and Forebays 3.13

$\begin{array}{ll}\text { 3.2.3 Comparisons within Fishways } & 3.20\end{array}$

$\begin{array}{lll}4.0 & \text { Discussion } & 4.1\end{array}$

$\begin{array}{lll}4.1 & \text { Laboratory Studies } & 4.1\end{array}$

4.2 Field Studies $\quad 4.2$

4.2.1 Swim Speed and Energy Use in the Tailraces, Fishways, and Forebays of

4.2.2 Swim Speeds and Energy Use among Sections of the Fishways of Bonneville Dam 4.5

5.0 Management Implications and Recommendations 5.1

$\begin{array}{lll}6.0 & \text { References } & 6.1\end{array}$ 


\section{Figures}

Figure 1.1. Bonneville Dam Powerhouses and Fishways ................................................................. 1.4

Figure 1.2. Reception Range of Antenna Arrays at Bonneville Dam................................................ 1.5

Figure 1.3. Mean Daily Water Temperature (heavy line) and Mean Daily Discharge (thin line) at

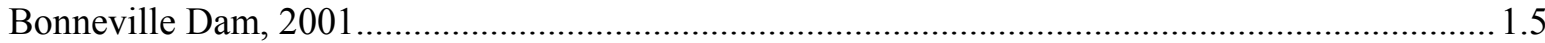

Figure 1.4. Mean Daily Discharge (m3 s-1) Over the Spillway or Through Two Different Powerhouses

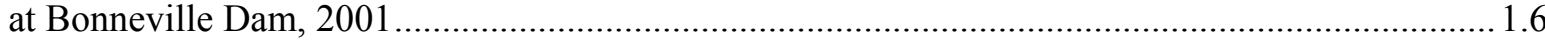

Figure 1.5 Sections of the Bradford Island Fishway. Section 6 is immediately in front of the counting window.

Figure 2.1. Process for Determining Swimming Speeds and Energy Use from Signals Received from EMG Transmitters Implanted in Spring Chinook Salmon

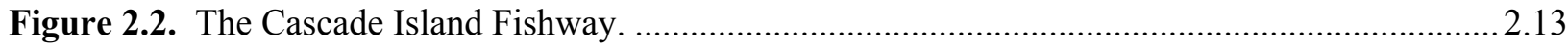

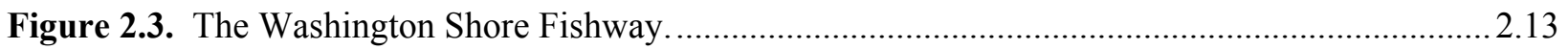

Figure 3.1. Observed Oxygen Consumption (data points) and Fitted Cubic Model by 45 Individual Spring Chinook Salmon (solid lines.

Figure 3.2. Observed Oxygen Consumption (data points) and Fitted Model 2 (solid lines) with Lower and Upper 95\% Confidence Bounds (dashed lines)

Figure 3.3. Distribution of Upper Critical Swimming Speeds for 22 Adult Spring Chinook Salmon with Swimming Speeds Expressed as (A) cm s-1 and (B) body lengths per second (B1 s-1)..........3.3

Figure 3.4. Red (circles) and White (squares) Muscle Electromyograms (EMGs; pulses $\mathrm{min}^{-1}$ ) by Swim Speed $\left(\mathrm{cm} \mathrm{s}^{-1}\right)$ for 10 Adult Spring Chinook Salmon.

Figure 3.5. Fitted Models for Red and White Muscle Electromyograms by Swim Speed $\left(\mathrm{cm} \mathrm{s}^{-1}\right)$ for 10 Adult Spring Chinook Salmon..

Figure 3.6. Box Plots of Mean Swimming Speeds (in $\mathrm{cm} \mathrm{s}^{-1}$ (Panel A), and BL s${ }^{-1}$ (Panel B)) of 85 Spring Chinook Salmon at Three Different Areas during Passage of Bonneville Dam, April June, 2001.

Figure 3.7. Box Plots of Mean Energy Use Rates (Panel A) and Energy Used (Panel B) by Spring Chinook Salmon at Three Different Areas during Passage of Bonneville Dam, April June, 2001.

Figure 3.8. Box Plots of Total (aerobic and anaerobic combined) Energy Use Rates (Panel A) and Total (aerobic and anaerobic combined) Energy Used (Panel B) by Spring Chinook Salmon at Three Different Areas during Passage of Bonneville Dam, April - June, 2001. 
Figure 3.9. Percent Cumulative Distribution of Total (aerobic and anaerobic combined) Energy Used by Spring Chinook Salmon to Pass Three Areas of Bonneville Dam (A=tailraces, $\mathrm{B}=$ fishways, $\mathrm{C}=$ forebays) April - June 2001 .

Figure 3.10. Box Plots of Mean Swimming Speeds (in $\mathrm{cm} \mathrm{s}^{-1}$ (Panel A), and BL s${ }^{-1}$ (Panel B)) of 76 Spring Chinook Salmon in Three Different Tailraces during Passage of Bonneville Dam, April June, 2001..

Figure 3.11. Box Plots of Energy Use Rates in Three Different Tailraces (Panel A) and Three Different Forebays (Panel B) by Spring Chinook Salmon as They Passed Bonneville Dam, April - June, 2001.

Figure 3.12. Box Plots of Total (aerobic and anaerobic combined) Energy Use Rates in Three Different Tailraces (Panel A) and Three Different Forebays (Panel B) by Spring Chinook Salmon as They Passed Bonneville Dam April - June, 2001

Figure 3.13. Box Plots of Mean Swimming Speeds (in $\mathrm{cm} \mathrm{s}^{-1}$ (Panel A), and BL s ${ }^{-1}$ (Panel B)) of 45 Spring Chinook Salmon in Three Different Forebays during Passage of Bonneville Dam, April June, 2001.

Figure 3.14. Box Plots of Swimming Speed (Panel A) and Energy Use Rates (Panel B) of Spring Chinook Salmon at Three Different Areas of Dam Passage during Both Day and Night (shaded half) at Bonneville Dam, April - June, 2001.

Figure 3.15. Box Plots of Energy Use Rates of Spring Chinook Salmon at Three Different Areas of Dam Passage during both Day and Night (the shaded half of the figures) at Bonneville Dam, April - June, 2001.

Figure 3.17. The Time of Day when Fish Entered (Panel A) and Exited (Panel B) Fishways during their Successful Passage of Bonneville Dam, April - June, 2001

Figure 3.19. Box Plots of Time (h) Spring Chinook Salmon Took to Pass Three Fishways (Washington shore, Cascade Island, and Bradford Island) at Bonneville Dam, April - June, 2001.

Figure 3.20. Box Plots of Swimming Speeds (in $\mathrm{cm} \mathrm{s}^{-1}$ in Panel A and in BL s $\mathrm{s}^{-1}$ in Panel B) of Spring Chinook Salmon in the Washington Shore, Cascade Island, and Bradford Island Fishways as They Passed Bonneville Dam, April - June, 2001

Figure 3.21 Box Plots of Energy Use Rates of Spring Chinook Salmon in Washington Shore, Cascade Island, and Bradford Island Fishways as They Passed Bonneville Dam, April - June, 2001.........3.25

Figure 3.22. Box Plots of Energy Use by Spring Chinook Salmon in Three Different Fishways (Washington Shore, Cascade Island, and Bradford Island) as They Passed Bonneville Dam, April - June, 2001.3.

Figure 3.23. Plots of the Amount of Time (h) Spring Chinook Salmon Spent in Three Different Fishways During Fallout (Washington Shore, Cascade Island, and Bradford Island) as They Attempted to Pass Bonneville Dam, April - June, 2001 
Figure 3.24. Box Plots of Swimming Speeds (in $\mathrm{cm} \mathrm{s}^{-1}$ in panel A and in BL s${ }^{-1}$ in panel B) of Spring Chinook Salmon during Fallout in Three Different Fishways (Washington Shore, Cascade Island, and Bradford Island) as they Attempted to Pass Bonneville Dam, April - June, 2001.

Figure 3.25. Box Plots of Energy Use Rates of Spring Chinook Salmon during Fallout in Three Different Fishways (Washington shore, Cascade Island, and Bradford Island) as They Attempted to Pass Bonneville Dam, April - June, 2001

Figure 3.26. Box Plots of Energy Use by Spring Chinook Salmon during Fallout in Three Different Fishways (Washington Shore, Cascade Island, and Bradford Island) as They Attempted to Pass Bonneville Dam, April - June, 2001

Figure 3.27. Box Plots of Swimming Speeds (in $\mathrm{cm} \mathrm{s}^{-1}$ in panel $\mathrm{A}$ and in $\mathrm{BL} \mathrm{s} \mathrm{s}^{-1}$ in panel $\mathrm{B}$ ) of Spring Chinook Salmon in Fishways during Day and Night as They Passed Bonneville Dam, April - June, 2001.

Figure 3.28. Box Plots of Energy Use Rates of Spring Chinook Salmon in Fishways during Day and Night as They Passed Bonneville Dam, April - June, 2001.

Figure 3.29. Plots of Swimming Speeds (Panel A) and Total Energy Use Rates (Panel B) of Migrating Spring Chinook Salmon in Fishways and the Number of Shad in Fishways at Bonneville Dam, April - June, 2001.

Figure 3.30. Plots of Swimming Speeds (Panel A), Total (aerobic and anaerobic combined) Energy Use Rates of Migrating Spring Chinook Salmon in Fishways (Panel B) and Number of Shad in Fishways (Panel C) and Water Temperature at Bonneville Dam, April - June, 2001. 


\section{Tables}

Table 3.1. Parameter Estimates for Two Linear Regression Models Relating Red and White Muscle EMGs to Swimming Speed (B1 s ${ }^{-1}$

Table 3.2. Mean Swimming Speed (+SE), Energy Use Rates (+SE), and Median Energy Used by Spring Chinook Salmon as they Passed Tailraces, Fishways, and Forebays of Bonneville Dam, April - June 2001..3.

Table 3.3. Mean Percentage (and range) of EMG Signals (emitted from an individual transmitter) Collected from Individual Spring Chinook Salmon Passing Bonneville Dam April - June 2001 that Are over Either 70, 80, or 100\% of the Critical Swimming Speed for Spring Chinook Salmon...... 3.9

Table 3.4. Swimming Speeds during Day and Night of Spring Chinook Salmon Passing Bonneville Dam, April - June 2001.

Table 3.5. Energy Use Rates during Day and Night of Spring Chinook Salmon Passing Bonneville Dam, April - June 2001..

Table 3.6. Median Energy Used by Spring Chinook Salmon as they Successfully Passed Fishways or Fell Out of Fishways of Bonneville Dam, April - June 2001..

Table 3.7. Mean Swimming Speeds (+SE) and Energy Use Rates (+SE) of Spring Chinook Salmon as they Successfully Passed Three Different Fishways or Fell out of Fishways, April - June 2001 . 3.24

Table 3.8. Mean Swimming Speeds (+SE) and Energy Use Rates (+SE) of Spring Chinook Salmon as they Successfully Passed Three Different Fishways during Day or Night, April - June 2001 ....... 3.31

Table 3.9. Mean Swimming Speeds of Spring Chinook Salmon in Different Sections of Three Different Fishways of Bonneville Dam, April - June 2001.

Table 3.10. Median Amount of Time Spring Chinook Salmon Spent in Different Sections of Three Different Fishways of Bonneville Dam, April - June 2001.

Table 3.11. Mean Energy Use Rates of Spring Chinook Salmon in Different Sections of the Three Fishways of Bonneville Dam, April - June 2001.

Table 3.12. Median Energy Used by Spring Chinook Salmon in Different Sections of Three Different Fishways of Bonneville Dam, April - June 2001

Table 3.13. Median Total Energy Used per Meter Length of Fishway by Spring Chinook Salmon in Different Sections of Three Different Fishways of Bonneville Dam, April - June 2001.....

Table 3.14. Total Energy Use Rates and Number of Hours Spent in Different Fishway Sections by Spring Chinook Salmon Passing Bonneville Dam, April - June 2001

Table 4.1. Energy Use Rates of Spring Chinook Salmon Passing Bonneville Dam, April - June 2001. 4.5 


\subsection{Introduction}

In 2000, the Pacific Northwest National Laboratory (PNNL) and the U.S. Geological Survey (USGS) initiated a two-year study to investigate the metabolic rate and swimming performance and to estimate the total energy used (i.e., aerobic and anaerobic) by adult spring chinook salmon (Oncorhynchus tshawytscha) migrating upstream through Bonneville Dam, a large hydropower dam on the Columbia River. The investigation, conducted for the U.S. Army Corps of Engineers, involved one year of laboratory study and one year of field study.

\subsection{Objectives}

The objectives of the laboratory study were to 1) measure active rates of oxygen consumption of adult spring chinook salmon at three water temperatures over a range of swimming speeds; 2) estimate the upper critical swimming speed (Ucrit) of adult spring chinook salmon; and 3) monitor electromyograms (EMGs) of red and white muscle in adult spring chinook salmon over a range of swimming speeds.

The objectives of the field study were to estimate the energetic costs incurred by salmon as they passed the tailraces, fishways, and forebays of the dam. We were particularly interested in the relative costs associated with passing different parts of fishways. Information on the activity and energy used by salmon as they migrate through these fishways will aide managers in maximizing fish passage while minimizing the amount of energy fish spend passing the dam. These measures will be helpful for improving recovery of Endangered Species Act-listed stocks.

This study used electromyogram (EMG) radiotelemetry to examine the amount of energy spring chinook salmon expended while passing Bonneville Dam. Although EMG telemetry has been used to examine the behavior and energy use of Pacific salmon in free-flowing reaches of rivers (Hinch et al. 1996, Hinch and Rand 1998, Rand and Hinch 1998, Hinch and Bratty 2000, Brown and Geist 2002), this technology has not been used to examine behavior and energy use while they migrate past a hydroelectric dam.

\subsection{Background}

Pacific salmon (Oncorhynchus sp.) are commonly known for their long spawning migrations. They may enter streams several months before spawning (Groot and Margolis 1991) and, because feeding stops when they enter freshwater (Greene 1926; Raleigh et al. 1986; Brett 1995), they have a finite amount of energy reserves with which to migrate, produce gametes, and complete their life history. In that time they may pass through up to eight dams to reach their spawning grounds in the highly developed Columbia River Basin.

A tremendous amount of research has been, and continues to be, conducted on the migrational behavior of Pacific salmon (Dauble and Mueller 2000). Within the Columbia River Basin, where hydroelectric development has significantly impacted this migrational behavior, thousands of adult salmon are implanted with radio transmitters during most years and their locations are noted at numerous points along their spawning migration. These studies have identified several possible ways in which the hydroelectric system has slowed or otherwise interfered with the migration of salmon. 
Two factors have emerged as major sources of delay at dams. The first is fallback, i.e., salmon ascend dams successfully, but later fall back over the spillway or other location (Liscom et al. 1985, Swan et al. 1994, Bjornn et al. 1999, Bjornn et al. 2000a), requiring a second ascent of the dam. Estimates of fallback rates for radio-tagged spring and summer chinook salmon, sockeye salmon $(O$. nerka), and steelhead (O. mykiss) at different dams on the Columbia River have ranged from 4\% to over 20\% (Bjornn et al. 1994, 1999a, 1999b, 2000a).

A second source of delay involves salmon not being able to successfully find the entrances to fishways. There are numerous sources of water discharge in the tailraces of hydroelectric dams, any of which can confuse salmon who are attracted to flow. Salmon may spend many hours in the swift waters of dam tailraces before finding the entrance to the fishways (Bjornn et al. 1995, 1998).

Migration delays at the dams, which can last for a few hours to several days per dam (Mendel et al. 1992; Bjornn et al. 1994; Mendel and Milks 1997; Dauble and Mueller 2000), can have several negative effects. A major concern is that, since salmon have limited energy reserves available to expend before death, any delay increases the likelihood that the fish will run out of energy en route or at spawning areas before successfully spawning (Berman and Quinn 1991). Delaying salmon at dams can also increase the likelihood of pre-spawning mortality (Beiningen and Ebel 1970; Gray 1990; Snelling et al. 1992) through predation by marine mammals, harvest by anglers, or mortality due to other sources (Dauble and Mueller 2000). Considering the depleted state of most wild salmon stocks, it is essential that the likelihood of successful spawning be maximized.

Although the main impact of delay at dams relates to the energetic state of the fish, most research has instead focused on the amount of time the fish spend in tailraces, fishways, and forebays of dams (Bjornn et al. 2000b). However, the amount of time a salmon spends at a location in the vicinity of a dam cannot be directly related to the amount of energy it consumes during that period, e.g., a salmon that is slowly swimming at the margin of a dam tailrace uses a dramatically different amount of energy than a salmon bursting through high-velocity water attempting to locate a fishway entrance.

Most of the salmon's upstream migration is accomplished by sustained swimming, which uses aerobic metabolism produced in red muscle tissue (reviewed in Beamish 1978); this uses the majority of stored energy reserves contained within upstream migrating adult salmon. For example, $84 \%$ of the total energy used by upriver-migrating stocks of sockeye salmon in the Fraser River was attributed to swimming (Rand and Hinch 1998).

Although the majority of energy used during upstream migration originates from aerobic pathways associated with sustained swimming, Pacific salmon use their tremendous anaerobic capacity in spectacular jumps and leaps through fishways and other natural barriers. The proportion of anaerobic metabolism in sockeye salmon was estimated to be $36 \%$ in very difficult passage areas in the Fraser River (Rand and Hinch 1998). These bursts of energy exceed the upper critical swimming speed (Ucrit) and likely result in exhaustive exercise with severe physiological consequences that may affect reproductive success (Driedzic and Kiceniuk 1976; Wood et al. 1983; Cameron and Cech 1990; Tufts et al. 1991; Pagnotta and Milligan 1991). Campbell et al. (1992) reported that exposure of female hatchery rainbow trout to acute stress (e.g., swimming to exhaustion) resulted in smaller egg size, delayed ovulation, and lower survival of larvae compared to unstressed fish.

Further, recent evidence suggests that the most efficient migrational behavior incorporates a series of burst and coast strategies that take advantage of micro-scale features of river channels with fish likely exceeding upper critical swimming speeds for only very short periods without resulting in fatigue (Hinch and Bratty 2000). Therefore, incorporation of anaerobic and aerobic metabolism into models of energy 
use by anadromous salmonids is needed to accurately predict the total amount of energy used during upstream migration.

Consequently, the use of EMG radio telemetry has become an effective method to estimate energy used by aerobic metabolism in adult salmon as they migrate to spawning areas (Hinch et al. 1996; Ǿkland et al. 1997; Hinch and Bratty 2000; Thorstad et al. 2000). EMG transmitters are surgically placed into the red muscle and EMG signals from these transmitters are calibrated against swim speed in a swim chamber. The calibration relationships are then used to convert EMG signals from free-swimming fish into estimates of swim speed and ultimately, if the relationship between oxygen consumption and swim speed is known, the swim speeds are expressed as measures of aerobic energy use (e.g., calories).

Catabolism of stored glycogen in white muscle tissue is the primary source of anaerobisis in fishes (Connor et al. 1964; Burgetz et al. 1998). Therefore, bioenergetic models often incorporate anaerobic energy use as a "tax" that is levied against the energy reserves based on how often fish swim at speeds that involve the use of white muscle (Rand and Hinch 1998). As the swimming speeds of fish approach Ucrit, the firing of red muscle fibers becomes saturated and white muscle is increasingly recruited.

Electromyography studies of muscle activity during sub-maximal swimming indicate that $80 \%$ of the Ucrit may be the threshold for when white muscle is recruited into swimming (Hudson 1973; Bone et al. 1978; Brill and Dizon 1979; Rome et al. 1985). However, Burgetz et al. (1998) found that the anaerobic component of swimming at speeds above $70 \%$ Ucrit results in a significant contribution to total energy used while Beddow and McKinley (1999) first noted consistent recruitment of white muscle at $86 \%$ of Ucrit levels. Accurately determining the swimming speed at which white muscle is recruited is necessary to determine the relative contribution of aerobic and anaerobic metabolism in the total energy used by migrating salmon.

Passage at each of the dams is facilitated by a variety of fishway designs. However, the behavior of fish and the amount of energy used during passage of these fishways is largely unknown. Bjornn et al. (1995) found that the amount of time from a salmon's first entry to a fishway to its successful exit of a fishway varied from an average of $\sim 13$ to 16 hours on the Snake River. This is $34 \%$ to $64 \%$ of the median time it takes chinook salmon to pass lower Columbia River reservoirs ( $\sim 20-47$ hours). Thus finding and passing fishways is a major component of the spawning migration. Unlike the reservoir passage component, it is a component that is amenable to human manipulation and improvement.

EMG telemetry can be useful for determining swimming behavior and its energetic consequences on a fine scale, making it possible to determine the swimming speeds (and consequently energy use) of fish throughout a dam's fishways (Hinch et al. 1996; Hinch and Rand 1998; Rand and Hinch 1998; Hinch and Bratty 2000; Brown and Geist 2002).

\subsection{Study Area}

This study was conducted from April to July 1, 2001, at Bonneville Dam (Figure 1.1 and 1.2). Bonneville Dam was constructed in 1938 and is located $234.9 \mathrm{~km}$ upstream of the mouth of the Columbia River. During the study period, the mean daily discharge was $3,784 \mathrm{~m}^{3} \mathrm{~s}^{-1}$ and daily averages ranged from $\sim 2,500$ to $\sim 5,000 \mathrm{~m}^{3} \mathrm{~s}^{-1}$ (Figure 1.3). These flows were much lower than the 10-year (1992-2001) average $\left(8,141 \mathrm{~m}^{3} \mathrm{~s}^{-1}\right)$. The majority of water discharge past Bonneville Dam is directed through two powerhouses or one central spillway (Figure 1.1). Flow in these areas varies depending on the operation of the dam. Figure 1.4 shows the fluctuations in water discharged through the two powerhouses and over 
the spillway during the study period. Water temperatures increased over the study period from $\sim 9^{\circ} \mathrm{C}$ to $18^{\circ} \mathrm{C}$ (Figure 1.3).

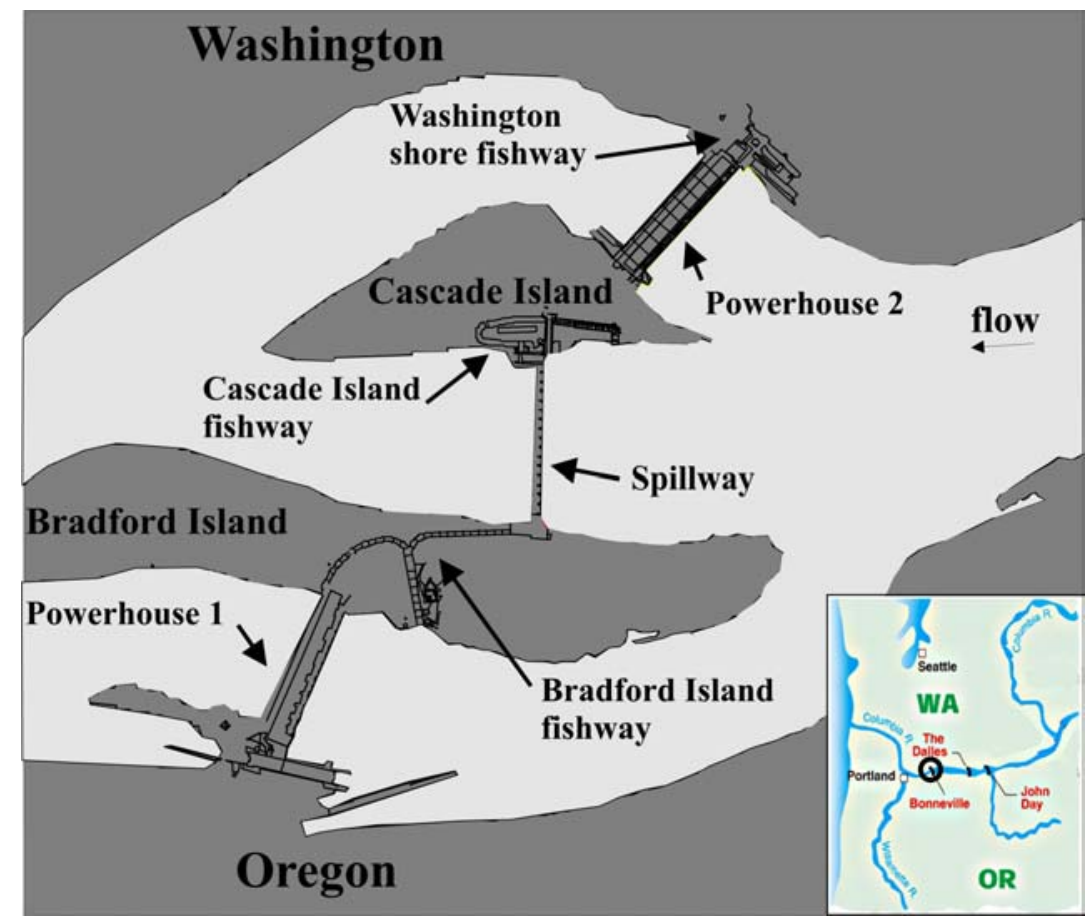

Figure 1.1. Bonneville Dam Powerhouses and Fishways

\subsubsection{Bradford Island Fish Ladder}

The Bradford Island fish ladder at Bonneville Dam has two branches (Figure 1.5), the A branch entrance is located along Powerhouse 1 and the $\mathrm{B}$ branch entrance is located at the south end of the spillway (USACE 1981). The length of the fishway is $373 \mathrm{~m}$ if fish pass through the A branch and $408 \mathrm{~m}$ if they pass through the B branch. The fishway has full-width overflow weirs $(9.14 \mathrm{~m}$ wide) in the main stem (Section 5) of the fishway. The two branches have full-width overflow weirs in the lower ends (the lower 19 weirs in the A Branch and the lower 17 weirs in the B Branch) and have restricted overflow weirs in the remainder of the A and B branches. The restricted overflow weirs have $2.67-\mathrm{m}-$ long overflow sections on each side. There is a height differential of $0.3 \mathrm{~m}$ between most weirs (weirs 10 to 15, which have $0.38 \mathrm{~m}$ differentials) and weirs are $4.9 \mathrm{~m}$ apart. All weirs contain an orifice on each end.

At the upper end of the main stem of the ladder is a fish counting station (USACE 1981). Between the counting slot (section 6) and the main stem of the fish ladder (part of section 6) is a triangular-shaped approach pool that is 1.5 to $2.1 \mathrm{~m}$ deep (part of section 6). This acts as a transition between the fish ladder and the counting slot. The counting slot (Section 6 in Figure 1.5) is $1.22 \mathrm{~m}$ wide, but can be adjusted down to $0.3 \mathrm{~m}$ wide to facilitate clear viewing of fish.

Between the counting window and the fishway exit is a section of vertical slot weirs. The 18 vertical slots divide the section into 17 pools. Slots vary from 0.7 to $1.2 \mathrm{~m}$ in width. For further detail on design of fishways at Bonneville Dam contact the USACE Hydraulic Engineering District Office, Portland, Oregon. 


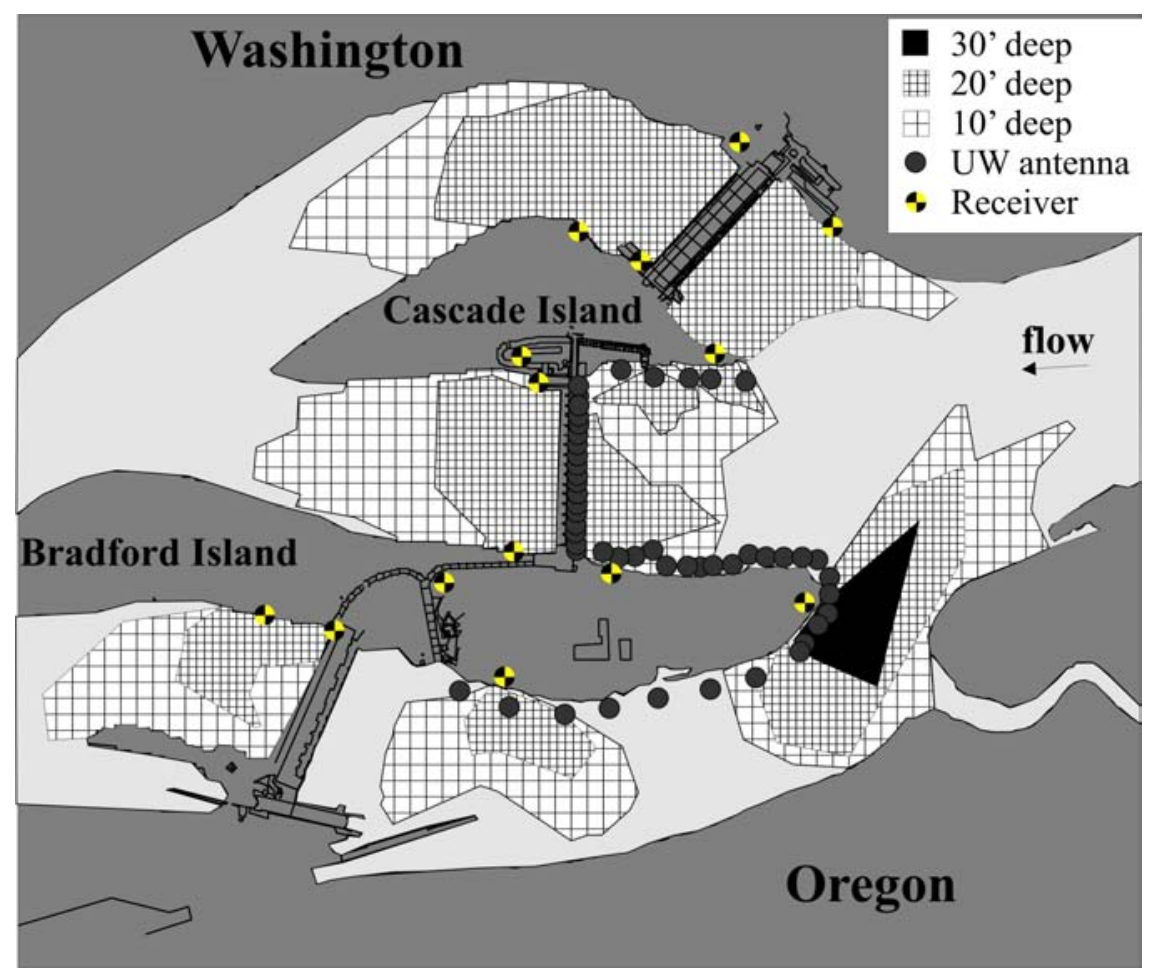

Figure 1.2. Reception Range of Antenna Arrays at Bonneville Dam. Underwater antenna reception areas are shown as dark circles; aerial antenna reception areas are shown as polygons with different patterns, depending on depth. Water depth is considerately deeper in some areas than in the reception zone. For bathymetry see Rakowski and Richmond (2000).

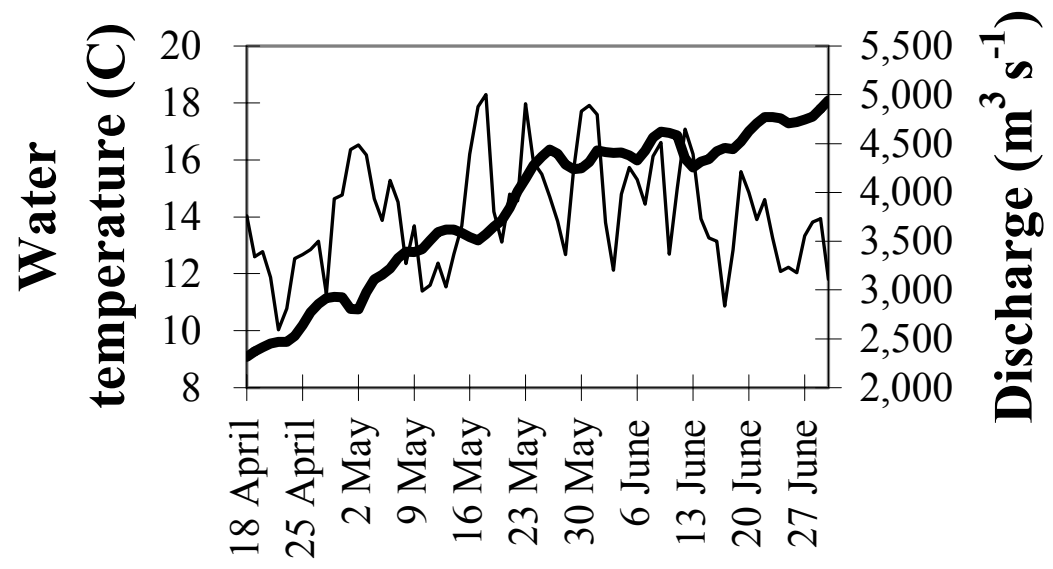

\section{Date}

Figure 1.3. Mean Daily Water Temperature (heavy line) and Mean Daily Discharge (thin line) at Bonneville Dam, 2001 


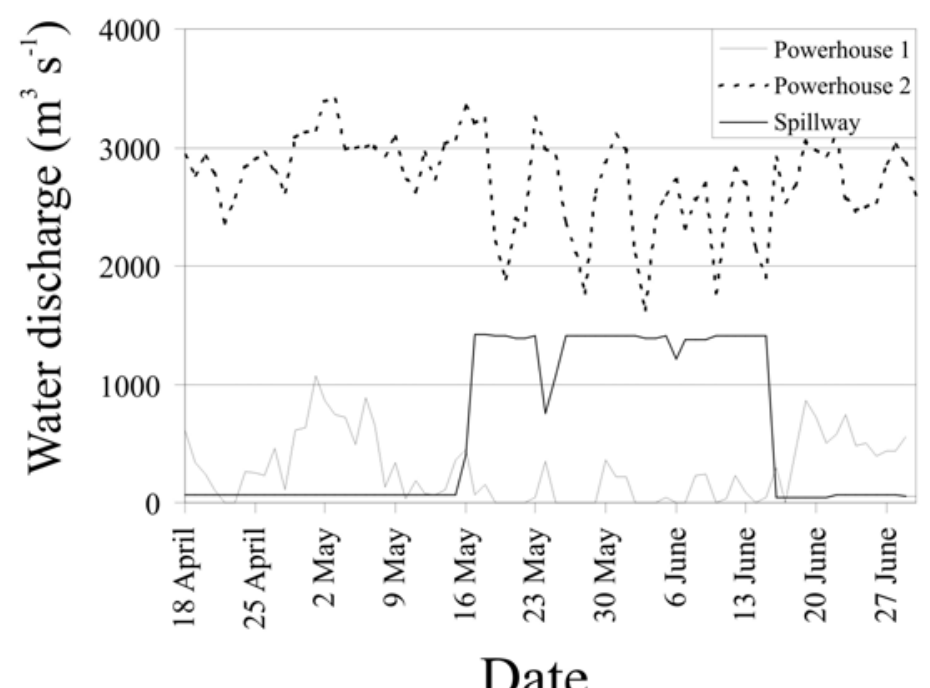

Figure 1.4. Mean Daily Discharge (m3 s-1) Over the Spillway or Through Two Different Powerhouses at Bonneville Dam, 2001

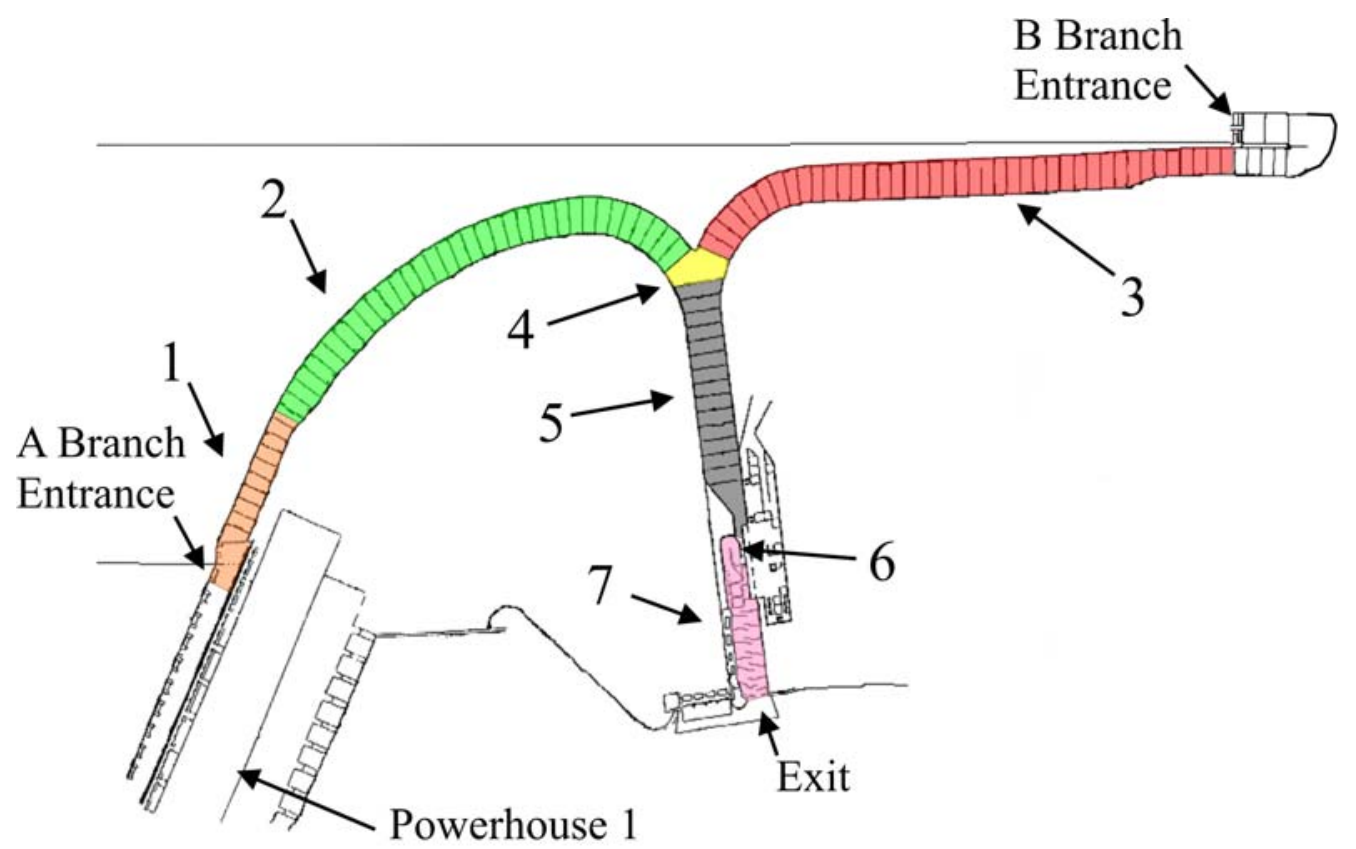

Figure 1.5 Sections of the Bradford Island Fishway. Section 6 is immediately in front of the counting window. 


\subsubsection{Cascade Island Fish Ladder}

The Cascade Island fish ladder has been modified from its original construction (at a length of 400 $\mathrm{m})$. Originally fish were guided from its entrance at the tailrace of the spillway to the forebay of the spillway. However, this exit has been closed and fish are diverted through the underground migrant tunnel (UMT; which is $\sim 156 \mathrm{~m}$ long) to the Washington Shore fishway, through which they exit into the forebay of Powerhouse 1. The size, gradient, and spacing of the overflow weirs are similar to the Bradford Island fishway. All weirs contain an orifice on each end, and these orifices are $61 \mathrm{~cm}$ high and wide.

\subsubsection{Washington Shore Fish Ladder}

Most of the Washington shore fish ladder is composed of full overflow weirs. The size, gradient, and spacing of the overflow weirs are similar to those of the Bradford Island fishway. All weirs contain an orifice on each end; these orifices are $46 \mathrm{~cm}$ high and wide. At the upper end of the main stem of the ladder is a fish counting station that contains a counting window. Between the counting window and the fishway exit is a section of vertical slot weirs. The vertical slots divide the section into 17 pools. 


\subsection{Methods}

\subsection{Laboratory Studies}

The following sections describe respirometer trials of adult spring chinook salmon Ucrit and EMG swim speed trials conducted at the Pacific Northwest National Laboratory (PNNL), Richland, Washington, or the Columbia River Research Laboratory (CRRL), Cook, Washington

\subsubsection{Fish Collection and Holding}

We obtained 65 adult spring chinook salmon in May and June, 2000, from the Little White Salmon National Fish Hatchery, at Cook, Washington. These fish are normally spawned in the late summer to early fall and thus were relatively early in their reproductive development. All fish were transported in large, rectangular tanks (757 L) in pickup trucks to either PNNL or CRRL. For all transport, densities of fish were kept low ( $<12$ fish per trip), bottled oxygen was used to maintain dissolved oxygen levels at $\geq 100 \%$ air-saturation, and the water was treated with polyaqua $(160 \mathrm{ppm})$ and clove oil (ca.10 ppm) to reduce stress. Water temperature never increased more than $2{ }^{\circ} \mathrm{C}$ during any trip.

Upon arrival, 3 or 4 fish were randomly placed in each of three covered, outdoor circular tanks receiving well water of similar temperature to that at the hatchery $\left(7-9^{\circ} \mathrm{C}\right)$. At PNNL, the tanks were 1.8 $\mathrm{m}$ in diameter and had inflow rates of about $35 \mathrm{~L} \mathrm{~min}^{-1}$. At CRRL, tanks were $1.5 \mathrm{~m}$ in diameter and had flow rates of about 6 or $7 \mathrm{~L} \mathrm{~min}^{-1}$. All tanks had a water depth of about $50 \mathrm{~cm}$ and air stones to deliver atmospheric air from a compressor. Within 24 hours of arrival, fish were acclimated to either $8^{\circ} \mathrm{C}$, $12.5^{\circ} \mathrm{C}$, or $17^{\circ} \mathrm{C}$ by increasing water temperature at a rate of $2^{\circ} \mathrm{C}$ per day. All fish were allowed at least one week at their acclimation temperature before being used in experiments. All fish were treated for $1 \mathrm{~h}$ every 3 or $4 \mathrm{~d}$ with a static bath of formalin ( $37 \%$ formaldehyde) at a concentration of $0.17 \mathrm{~mL} \mathrm{~L}^{-1}$ to prevent fungal infections.

\subsubsection{Respirometry Trials}

We used swimming respirometry to determine the relation between metabolic rate (i.e., oxygen consumption) and swim speed. A total of 45 adult spring chinook salmon were exercised at the two laboratories $(n=24$ at PNNL and $n=21$ at CRRL). Fifteen fish were tested at each of the three temperatures (i.e., $8,12.5$, or $17^{\circ} \mathrm{C}$ ). Trials were conducted in either a 500-L Blazka (CRRL) or a 2,200L Brett-type (PNNL) respirometer. We used two respirometers to allow us to test a large number of fish in a fairly short period of time. The working section of the Blazka respirometer measured $142 \mathrm{~cm}$ long and $45.7 \mathrm{~cm}$ in diameter. The working section of the Brett respirometer measured $180 \mathrm{~cm}$ long and 39.4 $\mathrm{cm}$ in diameter. Water velocities in both respirometers were created by a propeller driven by a variablespeed motor.

We used linear regression to describe the relation between motor speed and water velocity (measured with flow meters inside the tunnel). The resulting equations were used to calculate the motor speed necessary to achieve a desired velocity. Because of the smaller diameter of the Brett respirometer, we used a correction factor to adjust velocities for solid blocking effects (Smit et al. 1971). During trials, both respirometers were sealed so that no gas exchange occurred. An electrified screen (Brett) or circular rings (Blazka) were used occasionally to keep fish from resting during trials. 
To start a trial, the respirometer was partially filled with water at the acclimation temperature. We then placed clove oil (11 to $12 \mathrm{ppm}$ ) into one randomly selected holding tank with the water flow on. This dose of clove oil served to calm fish prior to netting them out of the holding tank. When fish in the holding tank were quiescent, usually after about $5 \mathrm{~min}$, one individual was gently netted and placed in a large container filled with water and clove oil at a concentration of $50 \mathrm{ppm}$. When the fish was fully anesthetized, it was weighed (to the nearest $\mathrm{g}$ ), measured (fork length to the nearest $\mathrm{mm}$ ), and placed in the respirometer. The respirometer was then closed, completely filled with water, and partially covered with black plastic to calm the fish and provide incentive for them to swim in the middle or anterior section of the respirometer. The fish remained overnight with the respirometer being continually flushed with fresh water (i.e., flow through) and velocity set at $30 \mathrm{~cm} \mathrm{~s}^{-1}$.

The next morning, gas-impermeable tubing from a peristaltic pump was connected to two valves at the top or side of the respirometer. The pump served to sample water $\left(60 \mathrm{~mL} \mathrm{~min}^{-1}\right)$ in a continuous loop from the respirometer to a sealed Plexiglas chamber containing an oxygen electrode connected to an electronic meter (WTW Oxi 340 meter and CellOx 325 probe) and back to the respirometer. The oxygen meter and probe were calibrated in air (i.e., $100 \%$ air-saturated) every day according to manufacturer's instructions, connected to a personal computer, and data (time, percent saturation of oxygen, and dissolved oxygen) were logged every 5 to $15 \mathrm{~s}$ using software supplied by WTW. After the oxygen monitoring equipment was set up, the respirometer was sealed by turning off the fresh water inflow and we started logging data from the first swim speed increment, $30 \mathrm{~cm} \mathrm{~s}^{-1}$. We recorded the starting time, percent saturation of oxygen, and dissolved oxygen $\left(\mathrm{mg} \mathrm{L}^{-1}\right)$ on a data sheet and logged data until the dissolved oxygen levels had dropped 0.15 to $0.30 \mathrm{mg} \mathrm{L}^{-1}$ from starting conditions.

When the dissolved oxygen concentration had dropped sufficiently, we recorded the final time, percent saturation, and dissolved oxygen concentration. At the end of any speed increment, if the percent air saturation was $>75 \%$ and water temperature had not increased more than $2^{\circ} \mathrm{C}$, we increased water velocity to the next speed increment and repeated the oxygen data logging procedure. If, however, the percent saturation was near $75 \%$ air-saturation or if water temperature had increased more than $2^{\circ} \mathrm{C}$, we reduced water velocity to $30 \mathrm{~cm} \mathrm{~s}^{-1}$ and flushed the respirometer with fresh water until we achieved $>$ $90 \%$ air-saturation and reduced water temperature to starting conditions. We then sealed the respirometer and repeated the above procedures.

Fish were tested at $30,50,70,90,110,130,150,170$, and $190 \mathrm{~cm} \mathrm{~s}^{-1}$; not every fish successfully completed all increments. Typically, at the lower velocities, fish were swum through about three increments before flushing the respirometer. As velocities increased $\left(\geq 90 \mathrm{~cm} \mathrm{~s}^{-1}\right)$, it was necessary to flush the respirometer with fresh water every one to two increments.

When fish completed as many speed increments as they were capable of, or willing to, water velocity was reduced to $30 \mathrm{~cm} \mathrm{~s}^{-1}$ and the respirometer was flushed with fresh water. Data from each increment were plotted as the decrease in dissolved oxygen versus time and checked visually for a linear relation. If a relation from any increment was substantially non-linear or highly variable, we would attempt to swim the animal again at that speed, but this was rare. After this quick check on the data, the respirometer was again sealed and we introduced a sleep dose of either MS $222\left(50 \mathrm{mg} \mathrm{L}^{-1}\right)$ or clove oil (ca.10 ppm) to facilitate removal of the fish from the swim tunnel. Fish were removed from the respirometers, uniquely marked with a colored floy tag, and returned to their holding tank. A blank trial (30 min) was performed after each fish trial to determine the amount of microbial oxygen use. Microbial oxygen use was normally undetectable but when present was subtracted from the oxygen use estimate of the previous fish. 
The oxygen consumption rate $\left(\mathrm{VO}_{2}\right.$ in $\left.\mathrm{mg} \mathrm{O}_{2} \cdot \mathrm{kg}^{-1} \cdot \mathrm{h}^{-1}\right)$ for an individual fish during a velocity increment was determined using the following equation:

$$
O_{2}=A \times V \times \frac{1}{W}
$$

where $\mathrm{V}$ was the volume of the respirometer $(\mathrm{L}), \mathrm{W}$ was the weight of the fish $(\mathrm{kg})$, and A was the rate of oxygen consumed $\left(\mathrm{mg} \mathrm{O}_{2} \cdot \mathrm{L}^{-1} \cdot \mathrm{h}^{-1}\right)$, minus the blank, during a velocity increment as determined by linear regression analysis of the reduction in dissolved oxygen levels over time $(\mathrm{t})$ :

$$
A=b_{o}+\left(t \times b_{1}\right)
$$

Data analysis was accomplished by first comparing fish weights and lengths between laboratories (i.e., CRRL or PNNL), water temperatures, and sex using analysis of variance. A series of linear regression models were then compared to determine the best model for predicting oxygen consumption as a function of swimming speed (in $\mathrm{cm} \mathrm{sec}^{-1}$ or body lengths $\mathrm{sec}^{-1}$ ) and temperature. For all analyses, the natural logarithms $\left(\log _{\mathrm{e}}\right)$ of oxygen consumption rates were used to reduce the residual variance and within-class heterogeneity.

Since each fish was tested at only a single temperature, a third-order polynomial linear regression model of log oxygen consumption versus swim speed (X) was fit to each fish so that the third-order slope was common for all fish. That is, each fish had a separate intercept, separate slope associated with swim speed, separate slope associated with swim speed squared, and a common slope associated with swim speed cubed. A common third-order slope prevents distorted slope estimates for fish not tested at higher swim speeds. Analysis of variance of the estimated slopes and intercepts was then used to examine the differences between temperatures, laboratories, sex, and body size to determine the level of complexity in a regression model combining fish (e.g., common or separate slopes and intercept for each factor). Polynomial regression was used to remove patterns of curvature from the residuals. Regression was conducted using swim speed and swimming speed normalized by body length.

Combined fish models were compared based on the principle that the simplest model (i.e., the model with the least number of parameters) that best explained the variability explained by the full model (i.e., the model with more parameters) and yet still made biological sense was the preferred model (Ramsey and Schafer 1996). The statistic $\left(\mathrm{F}_{\text {calc }}\right)$ used to compare nested models was

$$
F_{\text {calc }}=\frac{\left(\frac{\operatorname{Reduced}(E S S)-\text { Full }(E S S)}{\operatorname{Reduced}(e d f)-\text { Full }(e d f)}\right)}{\operatorname{Full}(E M S)}
$$

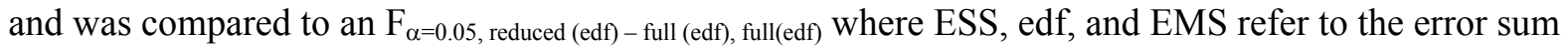
of squares, error degrees of freedom, and the error mean square (Ramsey and Schafer 1996). Competing nested models that were not found to be significantly different $(\alpha=0.05)$ from the full model and competing models that were not nested were determined to be more appropriate based on either a minimum error mean square or the model's biological relevance. All statistical analyses were done using JMP, version 4 (SAS Institute). 


\subsubsection{Critical Swimming Speed Trials}

A total of 22 adult spring chinook salmon were tested at the two laboratories ( $n=13$ at PNNL and $n=$ 9 at CRRL). We used the same respirometers as previously described to estimate the Ucrit of adult spring chinook salmon. Fish used in these trials were either some of those used in the respirometry trials or were unused fish. In all cases, fish were allowed at least 12 to $18 \mathrm{~h}$ of recovery after a respirometry trial before being used in a Ucrit trial. Water temperature for all Ucrit trials was $12.5^{\circ} \mathrm{C}$.

To start a trial, fish were anesthetized and placed in the swim tunnel as described for the respirometry experiments. After being placed in the respirometer, the fish were allowed at least $1 \mathrm{~h}$ of recovery under flow-through conditions (water velocity $30-50 \mathrm{~cm} \mathrm{~s}^{-1}$ ). After recovery, the water velocity was increased to $75 \mathrm{~cm} \mathrm{~s}^{-1}$ and the fish was swum for $30 \mathrm{~min}$. Water velocity was then increased $25 \mathrm{~cm} \mathrm{~s}^{-1}$ every $30 \mathrm{~min}$ until the fish fatigued. Fatigue was defined as when the salmon rested or became impinged on the downstream screen and would not leave despite several electric shocks. After fatigue was confirmed, the fish was removed from the swim tunnel. Critical swimming speed was calculated in body lengths per second $\left(\mathrm{BL} \mathrm{s}^{-1}\right)$ and in water velocity $\left(\mathrm{cm} \mathrm{s}^{-1}\right)$ using the formula described by Beamish (1978). For fish swum in the Brett respirometer, velocities were corrected for solid blocking effects, as described previously. Analysis of variance was used to compare Ucrit values between laboratories.

\subsubsection{Electromyogram Swim Speed Trials}

To document the relationship between EMG activity and swimming performance, EMG radio transmitters were surgically implanted into 10 individuals who were swum at defined speeds in the Brett respirometer at PNNL. The fish used in these trials were a sub-set of the fish used in the Ucrit tests done at PNNL. In all cases, fish were allowed $48 \mathrm{~h}$ of recovery after surgery before being used in an EMG trial. Water temperature was $12.5^{\circ} \mathrm{C}$ during all EMG swim trials.

Prior to EMG transmitter implantation, fish were anesthetized in $35 \mathrm{~L}$ of water using $50 \mathrm{ppm}$ of clove oil until they reached a stage 4 to 5 of anesthesia (Summerfelt and Smith 1990). Fish were then placed ventral side up on a surgical table in an adjustable sling and their gills were flushed continuously with an aerated, temperature-controlled clove oil anesthetic $(30 \mathrm{ppm})$ using flexible tubing connected to a submersible pump. A 3-cm-long incision was made just off the mid-line about half-way between the posterior tip of the pectoral fin and the anterior edge of the pelvic girdle. A retractor was used to widen the incision and blunt forceps were used to create a space between the body wall and internal organs to safely complete the incision.

To insert the transmitter and implant the electrodes, a $25-\mathrm{cm}$-long shielded needle was slid along the inside body wall until the tip of the needle was 5 to $10 \mathrm{~cm}$ posterior to the incision. The needle was used to puncture and send the catheter through the body wall. The needle was removed and the antenna from the transmitter was threaded through the catheter, which was then removed. The transmitter was inserted into the body cavity and pushed slightly anterior of the incision.

The transmitters were epoxy-coated cylinders (length $=52 \mathrm{~mm}$; diameter $=16 \mathrm{~mm}$; weight in air $=$ $17.3 \mathrm{~g}$; Lotek Engineering, Inc., Ontario, Canada) that had a single $25-\mathrm{cm}$ antenna and two plastic-coated stainless steel wires (electrodes) extending from one end. Each electrode had a 7-mm-long, 1-mmdiameter 24-k gold rod attached to its end. The electrical impulses emitted by the muscles were detected and stored in a capacitor until a factory-set threshold (in $\mu \mathrm{V}$ ) was reached, at which time a radio pulse was transmitted. Therefore, increasing muscle activity resulted in an increase in the pulse rate (in ms) of transmitted radio signals (i.e., time between radio transmissions decreases; see Kaseloo et al. 1992). 
The gold rods were loaded singly into $1.5 \mathrm{~mm}$ grooves cut in the tips of two custom-made $16-\mathrm{g}$ needles and plungers. The needles were aligned, held in one hand, inserted deep in the body cavity, and pushed through the muscle going at a steep angle toward the lateral line. For placement of electrodes in the red muscle, the gold rods were discharged just under the skin at the lateral line; for placement in white muscle, the gold rods were discharged before reaching the red muscle at the lateral line. To discharge the gold rods, the plunger was pushed down while removing the needle, thus leaving the gold rod anchored in the muscle. We attempted to place the gold rods in alignment with one another and about $1 \mathrm{~cm}$ apart. To check for proper placement, we felt for the gold rods just under the skin (red muscle only) and, using a telemetry receiver, verified that the pulse rate of the transmitter had decreased, which would be expected in an anesthetized fish. Following placement of the transmitter, the incision was closed with 4 to 5 simple interrupted silk sutures and the fish was returned to its holding tank. Fish were allowed $48 \mathrm{~h}$ for recovery prior to starting the EMG swim trials.

To document the EMG-swim speed relations, we first applied a light dose of clove oil to the tank containing a test fish, gently removed the fish, and placed it in a container that had a stronger dose of anesthetic (50 ppm clove oil). When the fish was completely anesthetized, we logged at least 30 EMG values using a telemetry receiver. We considered these values to be EMGs of fish at rest and recorded the values onto a computer spreadsheet as they appeared on the receiver screen. The fish was then removed from the anesthetic and placed in the Brett respirometer, where it was allowed to recover for $1 \mathrm{~h}$ under flow-through conditions and velocity set at $30 \mathrm{~cm} \mathrm{~s}^{-1}$.

To record EMGs while fish were swimming, we set up a video camera connected to a monitor that viewed simultaneously a side view of the fish in the swim chamber and the face of a telemetry receiver. An observer with a computer was positioned in front of the monitor to record data. Fish were swam at 30, $50,70,90,110,130,150,170$, and $190 \mathrm{~cm} \mathrm{~s}^{-1}$; again, not all fish swam at each velocity. At each velocity, the observer would watch the fish and, if the fish was swimming steadily, would record EMG data from the telemetry receiver by typing it into the spreadsheet. Data were not recorded if the fish was showing aberrant behavior such as burst swimming or resting. Fish would be encouraged to swim by briefly electrifying the downstream screen.

Fish swam at each speed until at least 30 data points were recorded before the velocity was increased to the next speed. Generally, it would take a few minutes at each speed to collect 30 data points. At higher swim speeds, it was sometimes difficult for the observer to record data because of the erratic behavior of fish and relatively fast data transmission. Therefore, we occasionally used videotapes of fish (all fish were videotaped) to record data from them swimming at high speeds.

After the last speed increment, the velocity was reduced to $30 \mathrm{~cm} \mathrm{~s}^{-1}$, and data were examined by plotting mean EMG output at each swim speed. For red muscle, we expected the time between pulses to decrease (indicating increasing muscle activity) linearly up to speeds approaching Ucrit. For white muscle, we expected minimal activity at low speeds and increasing muscle activity as speeds approached Ucrit and above. Fish were re-swum at any speed that was an obvious outlier on the observed trend line, but this was rare. When a trial was complete, the fish was removed from the respirometer, placed in a sleep dose of clove oil (50 ppm), and sacrificed by a blow to the head. The electrodes were dissected out to record the distance from the nose to the center of the electrodes, the distance between electrodes, the depth of the electrodes below the skin, and electrode orientation and location (red or white muscle).

Data analysis was accomplished using linear regression which fit muscle EMG data to swimming speed expressed both in $\mathrm{cm} \mathrm{s}^{-1}$ and body lengths $\mathrm{sec}^{-1}$ in separate models. The base model took a piecewise linear form on two model segments. 


$$
\begin{array}{rl}
\operatorname{EMG}(x)=a 1+b 1 x & \mathrm{x}<\mathrm{x}_{0} \\
=a 2+b 2\left(x-x_{0}\right) & \mathrm{x}=>\mathrm{x}_{0}
\end{array}
$$

where

$$
x_{0}=(a 2-a 1) / b 1
$$

This was a generalization of a model form that has been used in toxicological threshold models and is sometimes referred to as the "hockey stick model" (Klepper and Bedaux 1997). These models were fit to red and white EMG muscle data separately. The fitting procedure estimates four model parameters (intercepts: a1, a2; slopes: b1, b2) with the breakpoint between model segments $\left(\mathrm{x}_{0}\right)$ expressed as a function of $\mathrm{a} 1, \mathrm{a} 2$, and $\mathrm{b} 1$. The model is thus non-linear in $\mathrm{x}$. The fitting procedure uses an Iteratively Re-weighted Least Squares (IRLS) methodology with a Gauss-Newton optimization algorithm. In this manner, both model segments are fit simultaneously and meet at the breakpoint $\left(\mathrm{x}_{0}\right)$. The software used in this analysis was SAS ver. 8.2.

\subsection{Field Studies}

\subsubsection{Fish Collection and Tagging}

Ninety-six spring chinook salmon were captured at Bonneville Dam between April 12 and June 8, 2001. These fish had a mean weight of $6.0 \mathrm{~kg}$ (range $4.0-8.8 ; \mathrm{SD}=0.9$ ) and a mean fork length (FL) of $76 \mathrm{~cm}$ (range 68.0 - 85.5; $\mathrm{SD}=3.1$ ). Fish were captured in a trap inside the Washington shore fishway (Figure 1.1). While this trap was in operation, all fish were diverted from the fishway into a large tank and then into an aerated holding tank containing anesthetic (clove oil).

After the fish were anesthetized, they were carried in a sling approximately $100 \mathrm{~m}$ to a holding tank. Three fish were randomly placed in each of four covered, indoor circular tanks receiving fresh river water. Tanks were $1.5 \mathrm{~m}$ in diameter and had flow rates of about 6 to $7 \mathrm{~L} \mathrm{~min}^{-1}$; all tanks had a water depth of about $50 \mathrm{~cm}$.

Shortly after capture, all fish were surgically implanted with EMG transmitters. Each transmitter emitted signals on a unique frequency between 148 and $151 \mathrm{MHz}$. The transmitters were epoxy-coated cylinders (length $=52 \mathrm{~mm}$, diameter $=16 \mathrm{~mm}$, weight in air $=17.3 \mathrm{~g}$, and weight in water $=8 \mathrm{~g}$; Lotek Engineering, Inc., Ontario, Canada) that had a single $25-\mathrm{cm}$ antenna and two stainless steel, Teflon-coated wires (electrodes) extending from one end. Each electrode had a 7-mm-long, 1-mm-diameter, 24-k gold rod attached to its end. The EMG transmitter detected the electrical activity of the muscles. The electrical impulses emitted by the muscles were detected and stored in a capacitor until a factory-set threshold (in $\mu \mathrm{V}$ ) was reached, at which time a radio pulse was transmitted. Therefore, increasing muscle activity resulted in an increase in the pulse rate of transmitted radio signals (i.e., the time between the radio transmissions decreased; see Kaseloo et al. 1992).

Prior to EMG transmitter implantation, fish were anesthetized in $35 \mathrm{~L}$ of water using $50 \mathrm{ppm}$ of clove oil until they reached a stage 4 to 5 of anesthetization. Fish were then placed ventral side up on a surgical table in a groove cut in a piece of foam rubber and their gills were flushed continuously with an aerated, temperature-controlled clove oil anesthetic mixture $(30 \mathrm{ppm})$ using flexible tubing connected to a 
submersible pump. A 3-cm-long incision was made just off the mid-line about mid-way between the posterior tip of the pectoral fin and the anterior edge of the pelvic girdle.

To insert the transmitter and implant the electrodes, a 25-cm-long shielded needle was slid along the inside body wall until the tip of the needle was 5 to $10 \mathrm{~cm}$ posterior to the incision. The needle was used to puncture and send the catheter through the body wall. The needle was removed and the antenna from the transmitter was threaded through the catheter, which was then removed. The transmitter was inserted into the body cavity and pushed slightly anterior of the incision. The gold rods were loaded singly into 1.5 - $\mathrm{mm}$ grooves cut in the tips of two custom-made 16-g needles and plungers. The needles were aligned, held in one hand, inserted deep in the body cavity, and pushed through the muscle going at a steep angle toward the lateral line. The gold rods were discharged just under the skin at the lateral line. To discharge the gold rods, the plunger was pushed down while removing the needle, thus leaving the gold rod anchored in the muscle.

We attempted to place the gold rods in alignment with one another and about $1 \mathrm{~cm}$ apart. To check for proper placement, we felt for the gold rods just under the skin and, using a telemetry receiver, verified that the pulse rate of the transmitter had decreased, which would be expected in an anesthetized fish. Following placement of the transmitter, the incision was closed with 4 or 5 simple interrupted silk sutures and the fish was returned to its holding tank. Fish were allowed $48 \mathrm{~h}$ for recovery prior to calibrating EMG signals to swim speed.

\subsubsection{Calibration of EMG Signals to Swim Speed}

To document the EMG-swim speed relationship, we first applied a light dose of clove oil to the tank containing a test fish, gently removed the fish, and placed it in a container that had a stronger dose of anesthetic (50 ppm clove oil). When the fish was completely anesthetized, we logged at least 30 EMG values using a telemetry receiver (SRX 400, Lotek Engineering, Inc., Ontario, Canada). We considered these values to be EMGs of fish at rest and recorded the values onto a computer spreadsheet as they appeared on the receiver screen. The fish was then removed from the anesthetic and placed in the Blazka respirometer, where it was allowed to recover for $0.5 \mathrm{~h}$ under flow-through conditions and velocity set at $30 \mathrm{~cm} \mathrm{~s}^{-1}$.

The Blazka respirometer was used to calibrate the EMG tags to the swimming speed of each fish. The respirometer consisted of a tube containing $500 \mathrm{~L}$ of water and had a working section $142 \mathrm{~cm}$ long by $45.7 \mathrm{~cm}$ in diameter. Water velocity in the respirometer was created by a propeller driven by a variablespeed motor.

To record EMGs while fish were swimming, a video camera simultaneously filmed a side view of the fish in the swim chamber and the face of a telemetry receiver. An observer with a computer was positioned in front of a video monitor where the images of the fish and receiver were viewed. Fish were swam from 30 to $230 \mathrm{~cm} \mathrm{~s}^{-1}$ in $20 \mathrm{~cm} \mathrm{~s}^{-1}$ increments; not all fish swam at each velocity. At each velocity, the observer would watch the fish and, if the fish was swimming steadily, would record EMG data from the telemetry receiver by typing it into the spreadsheet.

Data were not recorded if the fish was showing aberrant behavior such as burst swimming or resting. Fish could be encouraged to swim by briefly electrifying the downstream screen. Fish swam at each speed until at least 30 data points were recorded before the velocity was increased to the next speed. Generally, it would take a few minutes at each speed to collect 30 data points. Occasionally, at higher 
swim speeds, telemetry data from videotapes of the swimming fish, were used to add some data if the fish did not swim long enough to obtain 30 data points.

After the last speed increment, the velocity was reduced to $30 \mathrm{~cm} \mathrm{~s}^{-1}$ and data were examined by plotting mean EMG output at each swim speed. We expected the time between pulses to decrease linearly (indicating increasing muscle activity) up to speeds approaching critical swimming speed (Ucrit, which is a measure of prolonged swimming performance; Beamish 1978, Webb 1995, Section 2.1 of this report). Fish were re-swum at any speed that was an obvious outlier on the observed trend line, but this was rare.

An equation describing the relationship between swimming speed and EMG pulse interval was determined for each individual fish in-situ and was used to estimate swimming speeds of fish in-vivo. A simple linear regression was used to describe this relationship. This method is used since this relationship is usually linear (as seen in Section 2.1). However, if fish swim at higher speeds in the wild than they did during calibration in the lab, estimates of swimming at higher speeds may not be accurate. We examined this possible source of inaccuracy of swimming speeds by determining the number of signals collected that were above calibration speeds. To do this, we first determined the mean EMG signal interval emitted by the transmitter while each fish was swimming at the highest velocity increment in the lab. Then we compared that to the signal intervals for field-collected EMG signals and the percentage of shorter field intervals (indicating faster swim speeds) for each fish was reported.

\subsubsection{EMG Signal Tracking}

After EMG tags implanted in fish were calibrated to swimming speed, the fish were placed in a large cooler and transported approximately 10 minutes to the release site. During transport, a small air pump was used to maintain dissolved oxygen levels near saturation, and the water was treated with polyaqua $(160 \mathrm{ppm})$ and clove oil (ca. $10 \mathrm{ppm})$ to reduce stress. Fish were released in one of two different locations; on the Washington shore $11.1 \mathrm{~km}$ downstream from Bonneville Dam and on the Oregon shore $9.5 \mathrm{~km}$ downstream from Bonneville Dam. Fish were released during daylight between April 18 and June 10.

As fish approached and passed Bonneville Dam, EMG signals were logged on up to nineteen SRX400 receivers and antenna arrays (Lotek Engineering, Inc., Ontario, Canada; Figure 1.2). A single antenna array was used to receive EMG signals from fish passing the Bradford Island fishway and another was used for the Cascade Island fishway. Two antenna arrays were used to monitor the Washington shore fishway. These arrays were tested to ensure that emissions from transmitters would be received in all areas of the fishways, yet not pick up signals from transmitters in the tailrace or forebay. Arrays of up to eight antennas were used to receive signals from fish that were located in the tailrace, fishways, or forebays.

Fishway antenna arrays consisted of multiple 4- or 6-element Yagi antennas (Model P150-4 or PLC 6, Cushcraft Corporation, Manchester, NH) while forebay and tailrace antennas consisted of 6- or 9element Yagi antennas (PLC 1509 Cushcraft Corporation, Manchester, NH). In all cases, antennas were grouped together using an ASP-8 antenna switch box. Receivers were set to group all antennas together and treat them as one large antenna. The reception range (Figure 1.2) of tailrace and forebay antenna arrays was tested by placing an EMG transmitter in the water at different depths (10, 20, and 30 feet deep) while boating through the forebays and tailrace. Locations where reception range faded were noted using a GPS. 
EMG signals from implanted salmon were also received using an array of underwater antennas attached to a computerized receiving system (Multiprotocol Integrated Telemetry Acquisition System [MITAS], Grant System Engineering, King City, Ontario, Canada). Fifty underwater antennas were spaced along the shore of the forebays of Powerhouse 1 and the spillway; 18 dipole antennas were placed along the spillway, and 32 balanced loop vee antennas (Model LVB-150-B; dB labs, Gretna, Nebraska) were placed along the shores of Cascade and Bradford Islands (distribution shown in Figure 1.2).

In addition to fixed reception arrays, manual trackers on foot and in trucks monitored EMG transmissions from implanted spring chinook salmon as they approached and passed the dam. Pick-up trucks were outfitted with 4- or 6-element Yagi antennas (models mentioned above). While trackers were walking they used three-element folding Yagi antennas (Advanced Telemetry Systems Inc., Isante, Minnesota).

As can be seen from Figure 1.2, signals from transmitters could not be received within all areas of the tailraces and forebays. Signals could not be received in some areas because the fish were too far from the antennas. In other areas, fish were too deep in the water column and signals would be attenuated before they reached the surface. Even if a fish is within the range of a receiving array, all signals from the transmitter will not be recorded. Each receiver must scan through several frequencies. While other frequencies are being scanned, the tag within the reception range is not logged. Likewise, if multiple fish are in the reception range, the amount of time each fish is logged decreases, while other fish are logged.

To estimate the percentage of time that signals were collected in each major area (tailraces, fishways, or forebays), EMG signals were summed and compared to the amount of time fish spent in the area. An EMG receiver logs the amount of time between consecutive radio signals. Thus, a sum of these signals provides an estimate of the amount of time that signals were received. In the fishways, it is estimated that signals were collected for a mean of $29 \%(\mathrm{SE}=4.6)$ of the time fish were present. In the forebays, this dropped to $22 \%(\mathrm{SE}=5.3)$ and it was only $7 \%(\mathrm{SE}=0.9)$ in the tailraces. Since fish are not constantly within the reception range of antennas in the forebays and tailraces, and fish were not constantly logged in fishways, data in this report do not give a full picture of fish behavior and energetics during dam passage. Instead, we attempted to provide an accurate representation of activity while fish are in each area. However, fish may consistently be missed in certain parts of tailraces or forebays (see Figure 1.2 for areas of reliable coverage) leading to a bias in reporting certain behaviors.

The signals emitted from the EMG transmitters were logged in the memory of the radio receivers and swimming speeds were estimated from these values (Figure 2.1). Swimming speeds for each individual fish were calculated using the relationship between swimming speed and the signals emitted from the EMG transmitter during calibration (method described previously). Swimming speeds estimated during the field study were compared to the critical swimming speed (Ucrit) of Columbia River spring chinook salmon (see Section 2.1). Critical swimming speed (Ucrit) is the maximum sustained swimming speed of a fish and represents a transition point over which the fish starts to rely heavily upon burst swimming. Burst swimming involves a higher proportion of white muscle (and thus anaerobic metabolism) than does sustained swimming, which relies primarily on red muscle (i.e., aerobic metabolism; Beamish 1978). 


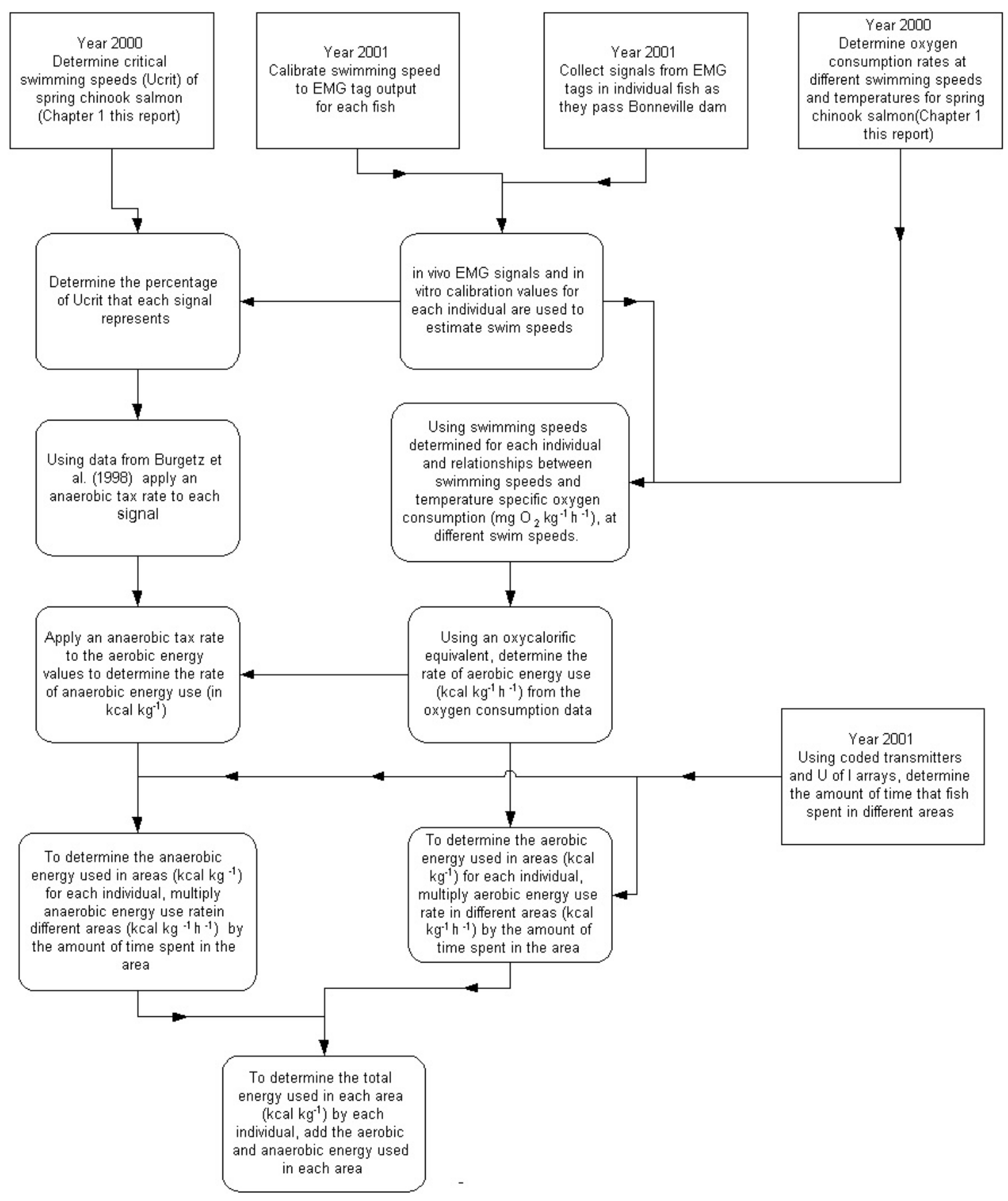

Figure 2.1. Process for Determining Swimming Speeds and Energy Use from Signals Received from EMG Transmitters Implanted in Spring Chinook Salmon

Swimming speeds were assigned a temperature-specific value for oxygen consumption $\left(\mathrm{mg} \mathrm{kg}^{-1} \mathrm{hr}^{-1}\right)$ using the relationship determined in Section 2.1 (Figure 2.1). Oxygen units ( $\mathrm{mg} \mathrm{kg} \mathrm{hr}^{-1}$ ) were converted to aerobic energy units $\left(\mathrm{kcal} \mathrm{h}^{-1}\right)$ using the oxycalorific average of $3.25 \mathrm{cal} \mathrm{mg} \mathrm{O}{ }_{2}^{-1}$ (Brafield and Solomon 1972). 


\subsubsection{Determination of Energy Use Rates}

During this study, EMG transmitters were only used to monitor the activity of the red muscle of spring chinook salmon. These muscles are fueled by aerobic, not anaerobic, pathways (Brett 1995). Anaerobic energy was estimated using the results of Burgetz et al. (1998). They found that, at different percentages of their Ucrit, rainbow trout (O. mykiss) obtained different amounts of energy through anaerobic pathways producing varying levels of lactate. They then applied a calorific equivalent to allow anaerobic energy use to be estimated. Since the amount of lactate produced (representing anaerobic energy) by fish varied with swimming speed, and oxygen consumption also varies with swimming speed, Burgetz et al. (1998) expressed the anaerobic metabolism as a percentage of the rate of oxygen consumption at a given speed (i.e., an anaerobic tax). As the swimming speed increased from $70 \%$ to $100 \%$ of the Ucrit, the anaerobic tax increased $(65 \%$ at $70 \%$ Ucrit; $69.2 \%$ at $80 \%$ Ucrit; and $205.0 \%$ at $100 \%$ Ucrit). Thus, when a fish is swimming at $100 \%$ Ucrit, the anaerobic costs of swimming are more than double the aerobic costs.

We took the three anaerobic tax values of Burgetz et al. (1998) and applied them to all EMG signals that were over 70\% Ucrit (using simple linear regression). Values over 100\% Ucrit received the same tax as those at $100 \%$ Ucrit. This tax was applied to the calorific values determined for aerobic energy to provide calorific values for anaerobic energy (in kcal).

Once aerobic and anaerobic energy use values were determined for each EMG signal, energy use of spring chinook salmon was summarized in the forebay, fishway, and tailrace areas of Bonneville Dam. Then, to identify a representative rate of energy use for each area, the mean of the energy use rate for each individual logged in each area was determined (Figure 2.1). The energy use rate within specific areas for each fish was multiplied by the amount of time that each fish spent in that area to determine total energy use in specific areas. Further comparisons were also made among the three different forebays and tailraces (Figure 1.2); more detailed analyses of fishways are reported in Section 3.2.3.

To examine differences, data were checked for normality. Since swimming speed and energy use rate data were normally distributed, factor analysis ANOVA was used for comparisons. Factor analysis ANOVA was used to determine if swimming speeds and energy use rates differed among the three major areas (tailrace, fishway, and forebay) and by sex. Differences in sex were controlled for by factor analysis ANOVA. Two factors were used: the first factor had three levels (tailrace, fishway, or forebay); the second factor had a two-level factor for sex (male or female).

Since data on time in areas and energy use were not normally distributed, Kruskal-Wallis tests were used. Throughout this report, when data are normally distributed, means are reported; otherwise, medians are reported.

Differences in swim speed or energy use rates were compared between day and night; data from twilight periods were excluded since they represent a small proportion of the day and may dilute the contrast effects of maximum darkness vs. full daylight. Factor analysis ANOVA was used to determine if swimming speeds and energy use rates differed between day and night within tailraces or forebays. To determine if there was a diel difference in these factors, the variation attributed to differences in different locations (spillway, powerhouse 1 or 2) of forebays or spillways was controlled for by factor analysis ANOVA. 
Two factors were used: the first factor had three levels (powerhouse 1, spillway, or powerhouse 2); the second factor had a two-level factor for diel period (day or night). Total energy used between day and night was not compared since antenna arrays were not designed to make exact determinations of when fish left one forebay or tailrace and entered another. Since this transition could not be accurately assessed, the time fish spent in individual tailraces or forebays could not accurately be measured, making total energy use (energy use rates * time) impossible to calculate.

Fish energy use in the tailrace was related to the spill over the spillway and the flow through the two powerhouses. The mean energy use rate was determined for each fish and related to the mean spill over the spillway or flow through the powerhouse while the fish was in a particular tailrace. However, since fish may not be actively attempting to ascend tailraces during the night, only data from the day were included in this analysis. To determine relationships between energy use in the tailraces and total energy use rates (aerobic and anaerobic combined), data were plotted and a general linear regression was applied.

For all statistical tests, alpha $=0.05$.

\subsubsection{Radio Tagging and Determination of Location in Fishways}

In addition to EMG tagging, each test fish was also tagged with a gastrically implanted radio tag. The radio signals were tracked on the University of Idaho's antenna arrays to determine fine-scale locations of the fish in the fishways. The radio tags used were model MCFT 7A (Lotek Engineering, Inc., Ontario, Canada). These transmitters were $16 \mathrm{~mm}$ in diameter and $83 \mathrm{~mm}$ long. They weighed $29 \mathrm{~g}$ in air and 13 $\mathrm{g}$ in water and had an estimated lifetime of 1,013 days. These transmitters emitted a coded pulse that allowed multiple transmitters to be received on a single frequency while retaining the ability to identify individual transmitters. Fish were placed in a container with anesthetic ( $\sim 30$ to $50 \mathrm{ppm}$ clove oil). Once fish attained stage seven anesthesia, they were grasped by the lower jaw and a plastic tube or smooth wooden dowel was used to gently ease the transmitter into the stomach.

The University of Idaho arrays consist of several underwater antennas placed at the entrances, exits, and throughout the fishways. These antennas consisted of a piece of coaxial cable with the terminal end stripped. The antennas were placed in the water and received signals from the coded transmitter in each spring chinook salmon, enabling small-scale changes in location to be noted. Antennas were linked to a receiver using digital-spectrum processors that scanned all transmitter frequencies almost simultaneously.

Entrances to the fishway were defined by at least two signals from coded tags being logged on the receiver at the fishway entrance (though it was very uncommon to pick up only two signals at the entrance). There were two types of entrances, successful and unsuccessful. An entrance was unsuccessful if a fish was logged at the entrance to a fishway or higher in the fishway, but did not successfully pass (was later logged in the tailraces). This behavior is referred to as "fallout." Successful fishway entries resulted in a fish progressing through the fishway and being logged at the fishway exit.

Passage was also divided up among different sections within fishways. The three fishways were divided into several sections as is shown in Figures 1.5, 2.2, and 2.3. EMG data for an individual fish in a section were only used if at least 30 EMG signals were logged. 


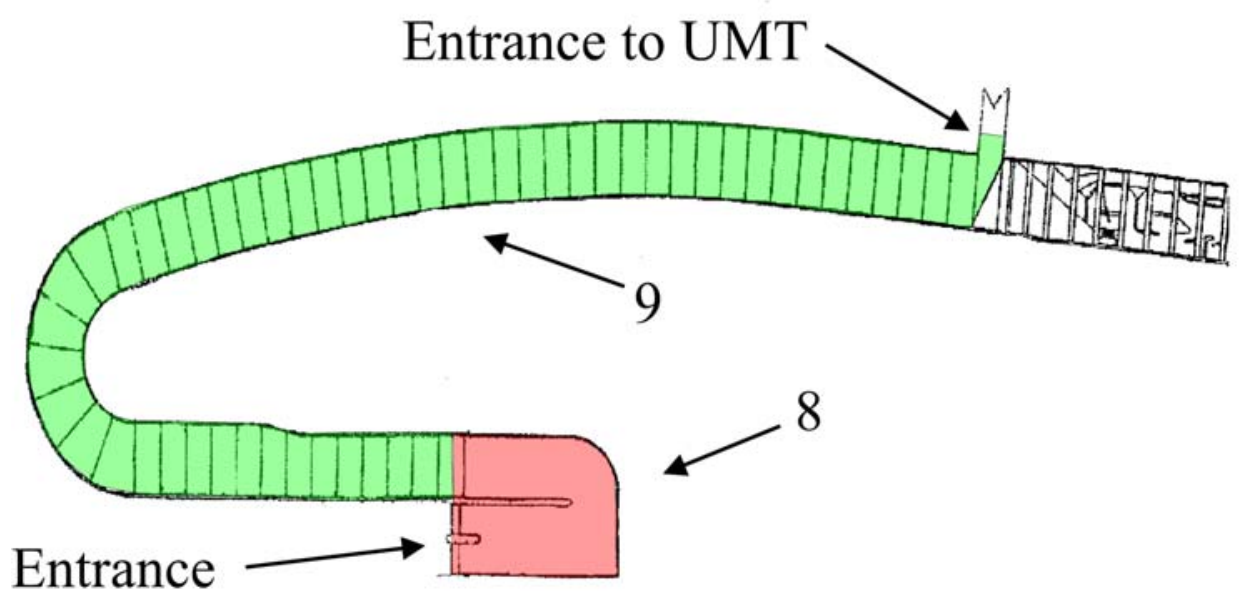

Figure 2.2. The Cascade Island Fishway. From upper end, fish enter the underground migrant tunnel (UMT)and travel through Powerhouse 2 into the Washington shore fishway.

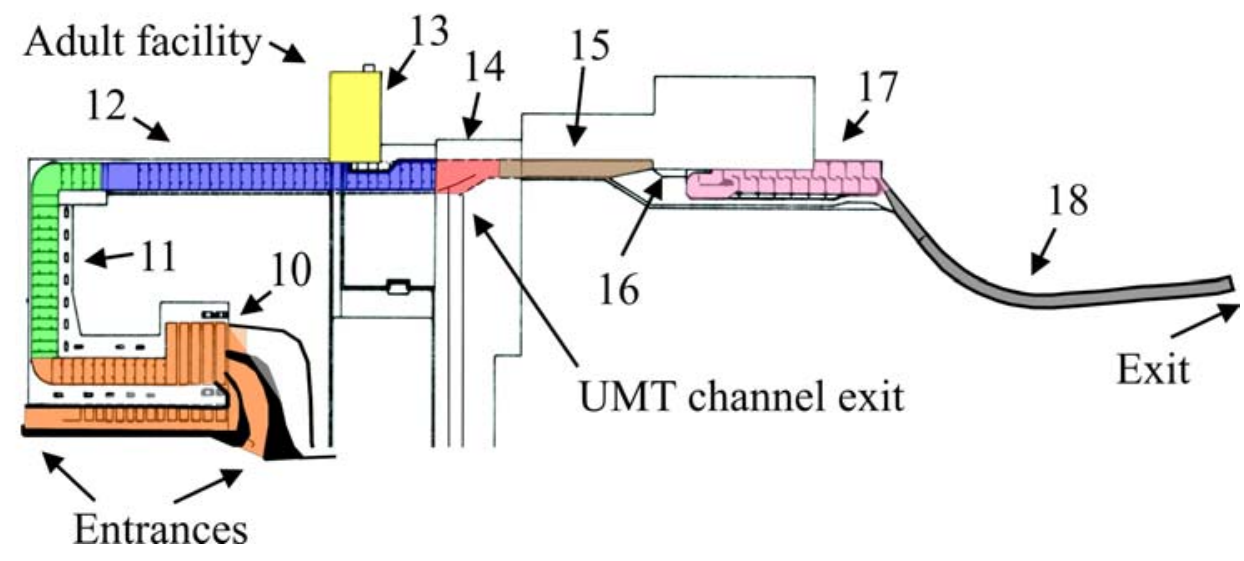

Figure 2.3. The Washington Shore Fishway. The underground migrant tunnel (UMT) enters the fishway at section 14. Section 16 (arrow) is immediately in front of counting window.

The fishways at Bonneville have several entrances. The fishways on each powerhouse have a south monolith entrance (not shown in figures). There is a channel that connects the south monoliths with the north monoliths. This channel runs along the face of the powerhouse and has several orifices through which fish can enter. However, it must be noted that during this study, we did not have enough equipment to monitor EMG signals from fish in the south monolith entrances to the Washington Shore or Bradford Island fishways. Also, we did not have enough equipment to record EMG signals from fish as they were in the fishways at the base of the two powerhouses.

Using detailed drawings of fishways, the length of each fishway section was estimated. This allowed energy used to be expressed per unit length $(\mathrm{m})$ of fishway.

Entry and exit times were compared among fish that exited a fishway on the same day they entered it and fish that spent one or more nights in a fishway. When data were normally distributed and variances 
did not differ, a $T$-Test was used; otherwise, a Mann Whitney $U$ test was used. These methods were also used to determine if there were differences in swimming speed, energy use rates, time spent in areas, and energy used in fishways between day and night, and also between fallouts and successful passages. Due to low sample sizes during twilight and night, only daytime data were used for this analysis.

If data were normally distributed and variances did not differ, ANOVA was used to determine whether there were differences in swimming speeds, energy use rates, times spent in the three different fishways, or the amount of energy used in different fishways. If these assumptions were not met, a Kruskal-Wallis test was used. Since there were no significant $(\mathrm{P}<0.05)$ differences in speed or energy use rates among fishways, the different fishways were not included as a factor in more detailed analysis.

Swimming speeds, energy use rates, energy use, and time spent in areas were ranked. In an effort to determine the relative energetic consequences of passage through each fishway section, rates of energy use and time spent in areas were combined into a single index. To accomplish this, the rankings of these two parameters were added. 


\subsection{Results}

\subsection{Laboratory Results}

Results from the laboratory studies conducted at PNNL and CRRL in 2000 are described in the sections below.

\subsubsection{Respirometry Trials}

Of the 45 fish used for the respirometry trials, 14 were males, 30 were females, and 1 was not identified. Fork lengths ranged from 67.0 to $80.4 \mathrm{~cm}$ and weights ranged from 3.7 to $6.4 \mathrm{~kg}$. Mean lengths and weights of fish were not significantly different between laboratories, sexes, or temperatures (ANOVA P $>0.13$ for all factors).

As expected, oxygen consumption increased with increasing swim speed for all fish. The individual fish model explained $98.5 \%$ (corrected for intercepts) of the total variance in oxygen consumption (Figure 3.1). Depending on water temperature, the model suggested oxygen consumption flattened out, or slightly declined, at or about 1.9 to $2.6 \mathrm{BL} \mathrm{s}^{-1}$ (ca.135 to $260 \mathrm{~cm} \mathrm{~s}^{-1}$ ); note that our empirical data on oxygen consumption was only measured up to $190 \mathrm{~cm} \mathrm{~s}^{-1}$ and values beyond this are interpolated by the best-fit model.

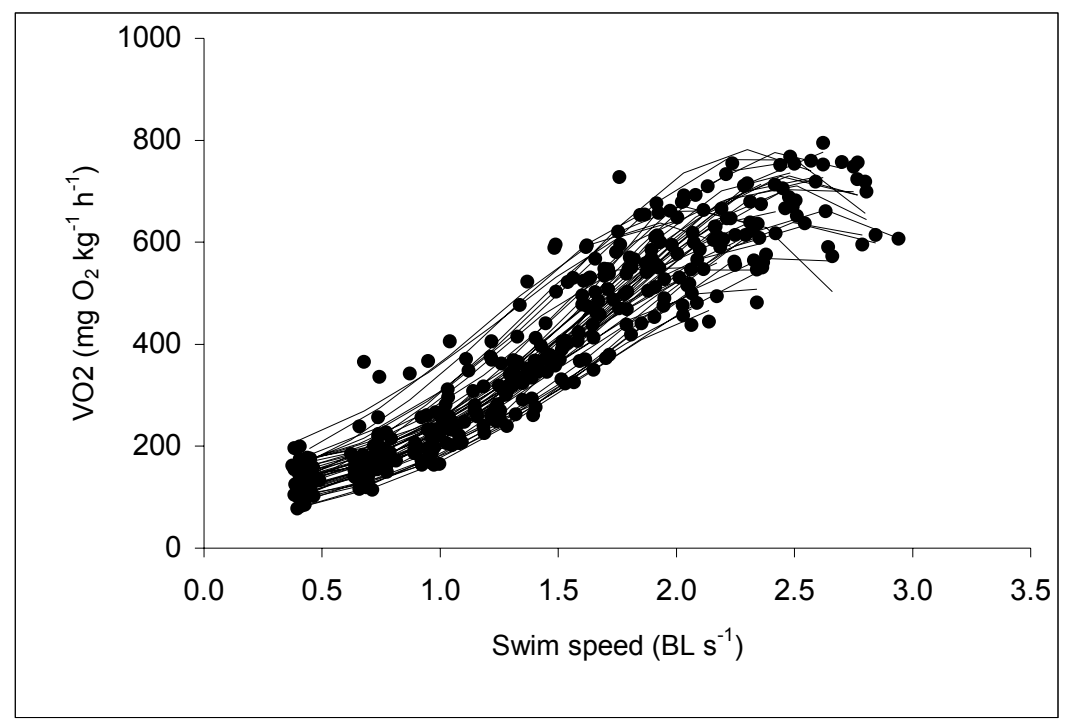

Figure 3.1. Observed Oxygen Consumption (data points) and Fitted Cubic Model by 45 Individual Spring Chinook Salmon (solid lines). All temperatures are combined.

Analysis of variance (ANOVA) of the 45 individual cubic model parameters for each laboratory, sex, length class, and weight class (four classes based on quartiles of the length and weight distributions) indicated that these factors had little influence on the $\mathrm{VO}_{2}$-swim speed relations. Although there was not a statistical difference in the intercepts of each model based on water temperature $(\mathrm{P}=0.11)$, there was a strong trend of increased base-line oxygen consumption with increased water temperature. Further, a model that incorporates temperature makes biological sense given the temperature range these fish could 
experience in the wild. The first- and second-order polynomial slopes were not significantly different between temperatures (ANOVA P $>0.60$ both factors) and did not display a trend. Thus, fish were combined and fit to two competing regression models. The first model (Model 1) had a separate intercept for each temperature and common slopes for the first- through third-order polynomial of swim speed, and the second model (Model 2) had a common intercept and slope for temperature and common slopes for the first- through third-order polynomial of swim speed.

Model 1 explained $93.2 \%$ of the total variance and can be expressed by the following fitted regression equations:

$\operatorname{LogVO}_{2}\left(\operatorname{temp~} 8^{\circ} \mathrm{C}\right)=4.38+0.770 * \mathrm{BL} \mathrm{s}^{-1}+0.335 *\left(\mathrm{BL} \mathrm{s}^{-1}\right)^{2}-0.128 *\left(\mathrm{BL} \mathrm{s}^{-1}\right)^{3}$;

$\operatorname{LogVO}_{2}\left(\operatorname{temp} 12.5^{\circ} \mathrm{C}\right)=4.50+0.770 * \mathrm{BL} \mathrm{s}^{-1}+0.335 *\left(\mathrm{BL} \mathrm{s}^{-1}\right)^{2}-0.128 *\left(\mathrm{BL} \mathrm{s}^{-1}\right)^{3}$; and

$\log \mathrm{VO}_{2}\left(\operatorname{temp} 17^{\circ} \mathrm{C}\right)=4.62+0.770 * \mathrm{BL} \mathrm{s}^{-1}+0.335 *\left(\mathrm{BL} \mathrm{s}^{-1}\right)^{2}-0.128 *\left(\mathrm{BL} \mathrm{s}^{-1}\right)^{3}$

where $\mathrm{BL} \mathrm{s}^{-1}$ is the swim speed in body lengths per second. Model 2 explained $92 \%$ of the total variance and can be expressed as:

$\log \mathrm{VO}_{2}=4.20376+0.026169$ temp $+0.7103 * \mathrm{BL} \mathrm{s}^{-1}+0.3699 *\left(\mathrm{BL} \mathrm{s}^{-1}\right)^{2}-0.1343 *\left(\mathrm{BL} \mathrm{s}^{-1}\right)^{3}$.

The variance explained by both models using swim speed in $\mathrm{cm} \mathrm{s}^{-1}$ was $93.9 \%$ and $93.8 \%$ for Model 1 and 2 respectively. However, the second- and third-order slope coefficients were extremely small (less than $6 \times 10^{-5}$ ); thus, this unit of measure was not considered further. Note, Model 1 is written as three equations only for convenience; these equations were fit simultaneously.

A reduced second-order polynomial was also fit to determine if the third order slopes could be removed. For both models, however, the second-order quadratic models were significantly different from the full model $(\mathrm{P}<0.01)$. Also, without the third-order slope in the model, the residuals displayed a curvilinear pattern. Thus, the reduced models were rejected. Finally, even though Model 2 explained slightly less of the variance than Model 1, Model 2 was chosen as the final model due to its flexibility of estimation with alternative temperatures. Due to round-off error, all decimal places should be used. The predicted $\mathrm{VO}_{2}$-swim speed relations, raw data, and $95 \%$ confidence intervals at the three temperatures derived from Model 2 are presented in Figure 3.2.

\subsubsection{Critical Swimming Speed}

Of the 22 fish used for the swimming performance tests, 7 were males, 13 were females, and 2 were not identified. Fork lengths ranged from 69 to $82 \mathrm{~cm}$ (mean $75.5 \mathrm{~cm}$ ) and weights ranged from 3.6 to $6.4 \mathrm{~kg}$ (mean $5.1 \mathrm{~kg}$ ). The Ucrits ranged from 125 to $196 \mathrm{~cm} \mathrm{~s}^{-1}$ (mean $154.7 \mathrm{~cm} \mathrm{~s}^{-1}$ ) and 1.6 to $2.7 \mathrm{BL} \mathrm{s}^{-1}$ (mean 2.05 $\mathrm{BL} \mathrm{s}^{-1}$; Figure 3.3). Analysis of variance showed that the mean fork lengths, weights, and Ucrit values $\left(B \mathrm{~B} \mathrm{~s}^{-1}\right.$ and $\mathrm{cm} \mathrm{s}^{-1}$ ) did not differ by sex (ANOVA P $>0.53$ all factors). Mean weights of fish were not significantly different between laboratories $(\mathrm{P}=0.41)$, but fork lengths of fish tested at CRRL were significantly greater $(\mathrm{P}=0.02)$ than fish tested at PNNL (mean FL 77.7 vs. $73.9 \mathrm{~cm}$ ) and the CRRL fish had significantly lower Ucrits measured by both $\mathrm{BL} \mathrm{s}^{-1}\left(\mathrm{P}=0.0003\right.$; mean 1.80 vs. $\left.2.23 \mathrm{BL} \mathrm{s}^{-1}\right)$ and $\mathrm{cm} \mathrm{s}^{-1}$ (ANOVA P $=0.005$; mean 140.2 vs. $164.8 \mathrm{~cm} \mathrm{~s}^{-1}$ ). 


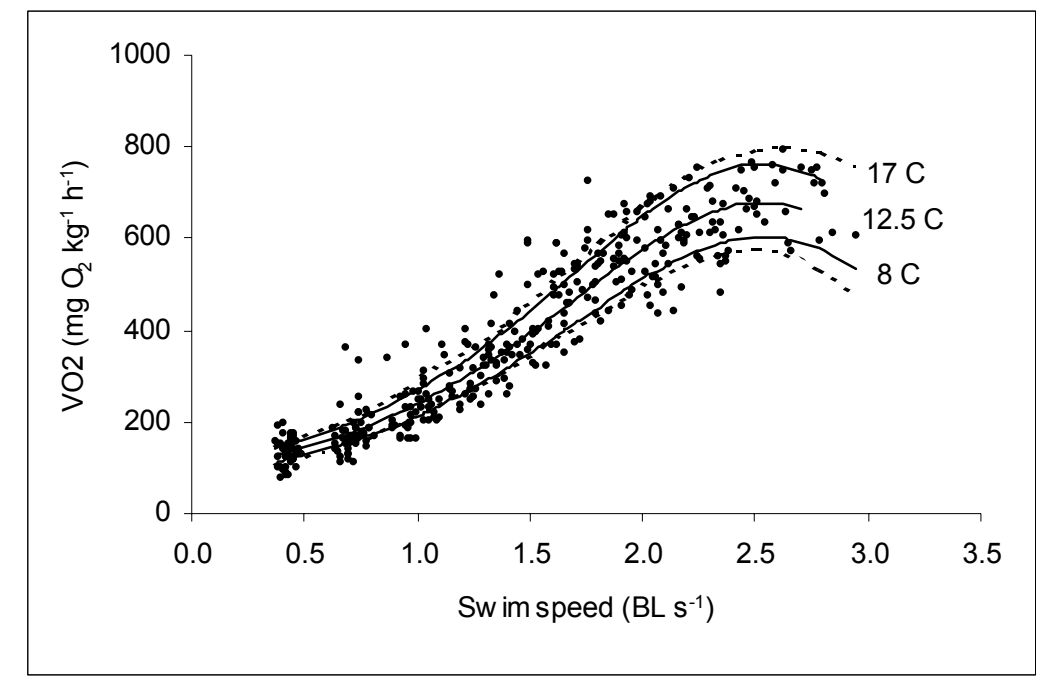

Figure 3.2. Observed Oxygen Consumption (data points) and Fitted Model 2 (solid lines) with Lower and Upper 95\% Confidence Bounds (dashed lines)

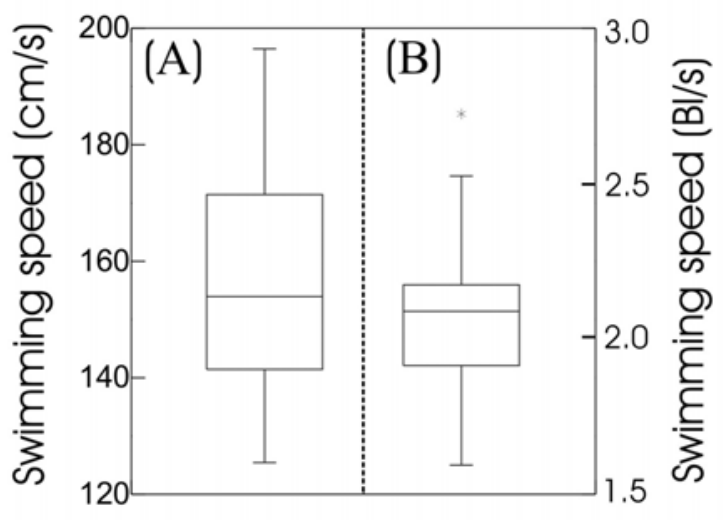

Figure 3.3. Distribution of Upper Critical Swimming Speeds (Ucrit) for 22 Adult Spring Chinook Salmon with Swimming Speeds Expressed as (A) cm s-1 and (B) body lengths per second (B1 s-1). For both plots, the line through the middle of the box represents the median, the upper and lower ends of the box represent the 75 th and 25 th percentiles of the distribution, and the upper and lower whiskers show the 90th and 10th percentiles of the distribution. Outliers ( $>1.5$ times the median) are shown by asterisks.

\subsubsection{Electromyogram-Swim Speed Relations}

Of the 10 fish used for the red and white EMG studies, 3 were males and 7 were females. Fork lengths ranged from 69 to $80 \mathrm{~cm}$ (mean $73.9 \mathrm{~cm}$ ) and weights ranged from 3.6 to $6.4 \mathrm{~kg}$ (mean $5.0 \mathrm{~kg}$ ). The Ucrits of these 10 fish ranged from 145 to $196 \mathrm{~cm} \mathrm{~s}^{-1}$ (mean $168.2 \mathrm{~cm} \mathrm{~s}^{-1}$ ) and 1.92 to $2.72 \mathrm{BL} \mathrm{s}$ (mean $2.28 \mathrm{BL} \mathrm{s}^{-1}$ ). Analysis of variance showed that the mean fork lengths, weights, and Ucrit values $\left(\mathrm{BL} \mathrm{s}^{-1}\right.$ and $\mathrm{cm} \mathrm{s}^{-1}$ ) did not differ significantly by sex (ANOVA P $>0.14$ for all factors).

As expected, EMG signals (pulse $\mathrm{min}^{-1}$ ) of red and white muscle increased with increasing swim speed for all fish (Figure 3.4). In all but one case (fish 10), the averaged EMG pulse rate of the red 
muscle was higher than the EMG pulse rate of white muscle at each swimming speed. The breakpoints at which the red and white muscle EMG pulse rates converged are nearly synchronized in their point estimates and confidence bounds, suggesting a nearly simultaneous shift from increasing red muscle activity $\left(<135 \mathrm{~cm} \mathrm{~s}^{-1}\right)$ to increasing white muscle activity $\left(>137 \mathrm{~cm} \mathrm{~s}^{-1}\right.$; Figure 3.5$)$.

Goodness-of-fit tests were highly significant (F-test; P $<0.0001)$ for both regression models (Table 3.1). This convergence point (135 to $137 \mathrm{~cm} \mathrm{~s}^{-1}$ ) is approximately $80 \%$ of the mean Ucrit for these fish $(95 \%$ confidence interval, $73 \%$ to $88 \%)$. A similar analysis of the red and white muscle EMGs using a model constructed with swim speed in $\mathrm{BL} \mathrm{s}^{-1}$ did not achieve convergence (not shown). For all fish, post-mortem dissections showed that all electrodes were firmly implanted in the appropriate muscle type. We did not note any malfunctioning transmitters during this phase of the study, but we did not re-swim fish to determine if transmitter drift occurred over time.

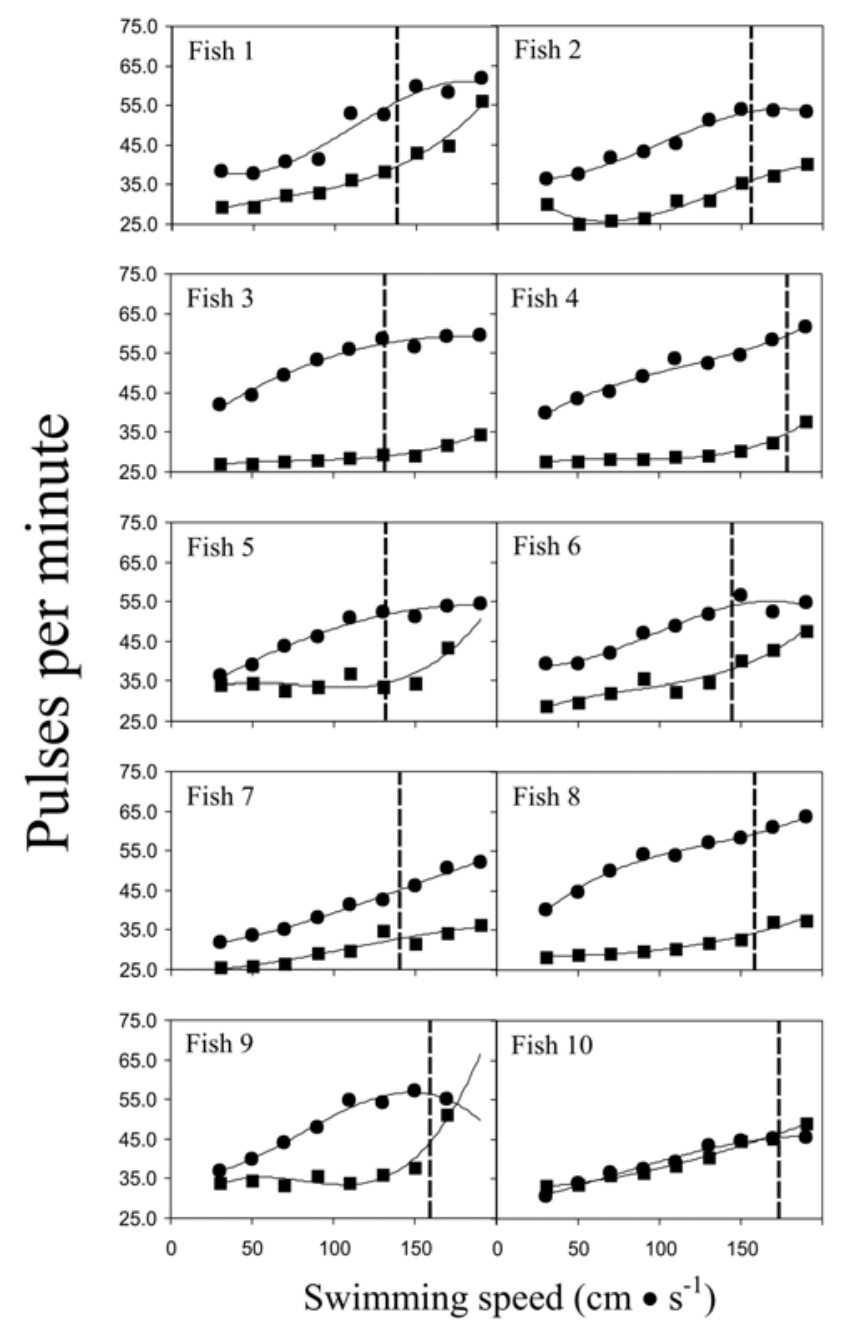

Figure 3.4. Red (circles) and White (squares) Muscle Electromyograms (EMGs; pulses $\mathrm{min}^{-1}$ ) by Swim Speed $\left(\mathrm{cm} \mathrm{s}^{-1}\right)$ for 10 Adult Spring Chinook Salmon. Solid line shows best fit for EMG values; dashed line shows Ucrit. 


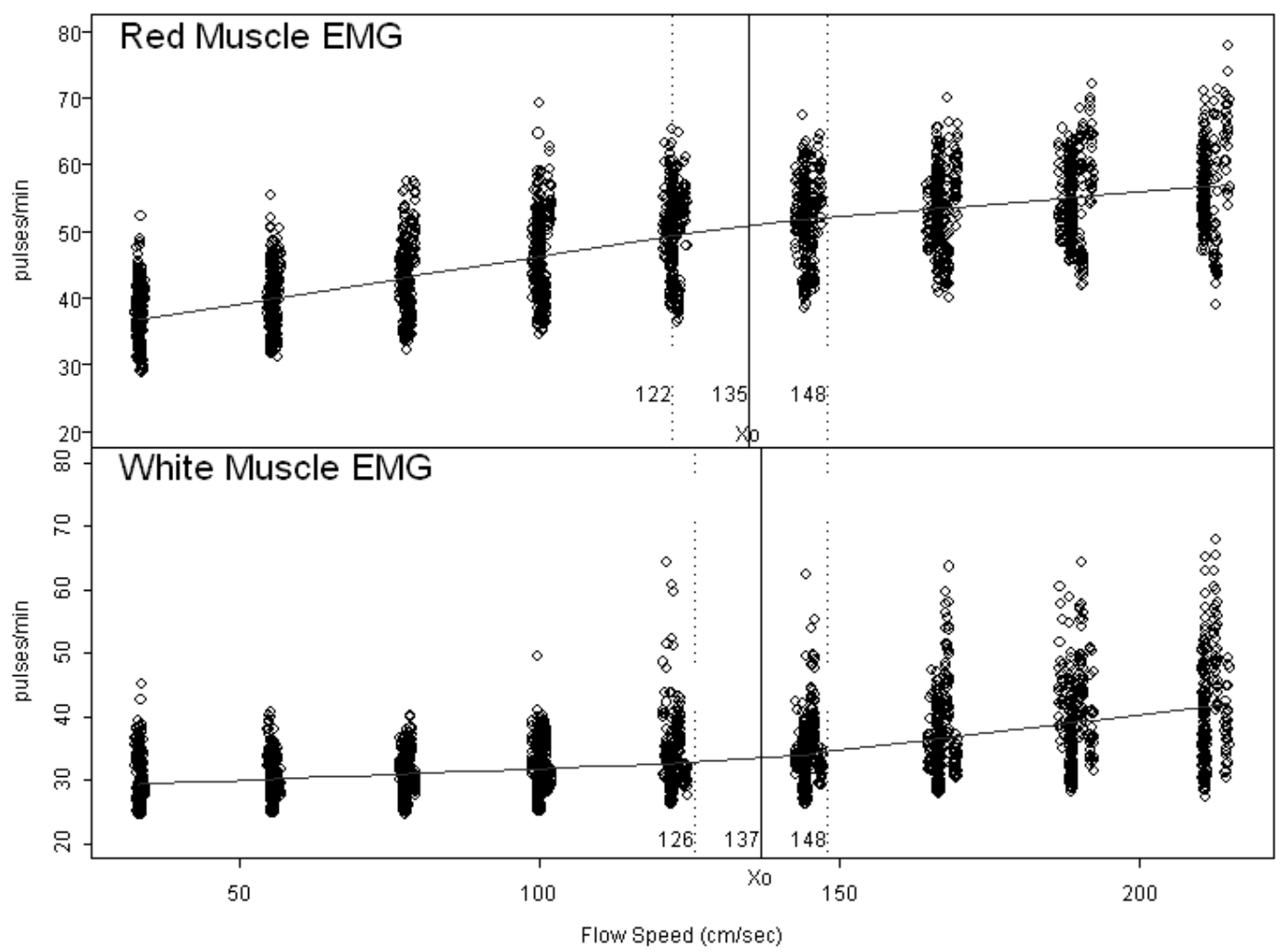

Figure 3.5. Fitted Models for Red and White Muscle Electromyograms by Swim Speed $\left(\mathrm{cm} \mathrm{s}^{-1}\right)$ for 10 Adult Spring Chinook Salmon. An approximate 95\% confidence interval is plotted for the estimated breakpoint $\left(\mathrm{X}_{0}\right)$ between model segments.

Table 3.1. Parameter Estimates for Two Linear Regression Models Relating Red and White Muscle EMGs to Swimming Speed $\left(\mathrm{B} 1 \mathrm{~s}^{-1}\right)$. The fitting procedure estimates four model parameters (intercepts: a1, a2; slopes b1, b2) with the breakpoint between model segments $\left(\mathrm{x}_{0}\right)$ a function of a1, a2, and b1. All parameter estimates were highly significant based on t-values $(\mathrm{p}<0.001)$.

\begin{tabular}{||r|c|c||}
\hline \multicolumn{1}{|c|}{ Parameter } & Coefficient (SE) & t-value \\
\hline Red EMG & \multicolumn{2}{|c||}{} \\
\hline $\mathrm{a} 1$ & $32.106(0.399)$ & 80.530 \\
\hline $\mathrm{b} 1$ & $0.141(0.005)$ & 29.780 \\
\hline $\mathrm{a} 2$ & $51.174(0.760)$ & 67.380 \\
\hline $\mathrm{b} 2$ & $0.072(0.007)$ & 9.910 \\
\hline $\mathrm{x}_{0}$ & $135.000(6.599)$ & 20.450 \\
\hline White EMG \\
\hline $\mathrm{a} 1$ & $28.132(0.377)$ & 74.650 \\
\hline $\mathrm{b} 1$ & $0.037(0.004)$ & 8.210 \\
\hline $\mathrm{a} 2$ & $33.174(0.467)$ & 71.090 \\
\hline $\mathrm{b} 2$ & $0.114(0.007)$ & 16.630 \\
\hline $\mathrm{x}_{0}$ & $137.000(5.571)$ & 24.590 \\
\hline
\end{tabular}




\subsection{Field Study Results}

Ninety-six spring chinook salmon were implanted with EMG transmitters and released below Bonneville Dam. Signals from either the EMG transmitters or the coded transmitters were logged from 88 (92\%) of these fish. Useful EMG signals were logged from 85 fish; with 76 of these fish detected in the tailraces, 81 detected in the fishways, and 45 detected in the forebays. Most of these fish (79 or 82\%) passed through the fishways successfully. Two fish entered fishways but did not successfully pass. Two fish that did not pass the fishways were logged in the navigation lock; one of these fish was later logged at several upstream dams, thus it likely passed the dam using the navigation lock. A mean of 8,858 (range 59 - 78,072) EMG signals were received from each implanted spring chinook salmon. Of these, a mean of 2,578 (range 59-22,391) EMG signals were received in the tailrace, 6,142 (range 168 - 73,146) signals were received in the fishways, and 1,346 (range $35-48,490$ ) signals were received in the forebay.

\subsubsection{Comparisons between Tailraces, Fishways, and Forebays}

\subsubsection{Swimming Speeds}

Swimming speeds of fish varied considerably by the area of the dam they were passing, but were significantly $(\mathrm{P}<0.05)$ highest in the tailraces (Table 3.2; Figure 3.6). Mean swimming speeds of spring chinook salmon in the tailraces $\left(1.40 \mathrm{BL} \mathrm{s}^{-1}\right)$ were $23 \%$ faster than in the fishways $\left(1.13 \mathrm{BL} \mathrm{s}^{-1}\right)$ and $32 \%$ faster than in the forebays $\left(1.06 \mathrm{BL} \mathrm{s}^{-1}\right)$. Although swimming speeds in the fishways were slightly higher than in the forebays $(\sim 7 \%)$, there was no significant difference between areas. Swimming speeds also exceeded Ucrit much more (26\% of the time) in tailraces than in either fishways (17\%) or forebays (13\%; Table 3.3).

\subsubsection{Time in Areas}

The time that spring chinook salmon spent in the tailraces was significantly higher than time spent in other areas (Table 3.2). For example, the median amount of time in the tailraces $(21.1 \mathrm{~h})$ was $\sim$ four times higher than the median amount of time spent in the fishways $(5.0 \mathrm{~h})$ and over 30 times higher than the time spent in the forebays $(0.7 \mathrm{~h})$. In addition, spring chinook salmon spent significantly ( $\sim$ seven times) more time in the fishways than in the forebays.

\subsubsection{Energy Use Rates}

The rates of energy used (i.e., $\mathrm{kcal} \mathrm{kg}^{-1} \mathrm{~h}^{-1}$ ) by spring chinook salmon were significantly higher in the tailraces than in any other part of the dam (Table 3.2; Figures 3.7 and 3.8). The mean energy use rate in the tailrace $\left(2.80 \mathrm{kcal} \mathrm{kg}^{-1} \mathrm{~h}^{-1}\right)$ was $26 \%$ higher than energy use rates for the fishways $\left(2.22 \mathrm{kcal} \mathrm{kg}^{-1} \mathrm{~h}^{-1}\right)$ and $62 \%$ higher than values recorded in the forebays $\left(1.73 \mathrm{kcal} \mathrm{kg}^{-1} \mathrm{~h}^{-1}\right)$. Although not significantly different, energy use rates in the fishways were $28 \%$ greater than in the forebays.

These trends in differences were also observed when aerobic and anaerobic energy use rates were examined separately (Figure 3.7). The only exception was that the differences in the mean anaerobic energy use rate approached significance $(\mathrm{P}=0.08)$ between the fishways $\left(1.11 \mathrm{kcal} \mathrm{kg}^{-1} \mathrm{~h}^{-1}\right)$ and forebays $\left(0.73 \mathrm{kcal} \mathrm{kg}^{-1} \mathrm{~h}^{-1}\right)$. 
Table 3.2. Mean Swimming Speed $( \pm \mathrm{SE})$, Energy Use Rates $( \pm \mathrm{SE})$, and Median Energy Used by Spring Chinook Salmon as they Passed Tailraces, Fishways, and Forebays of Bonneville Dam, April - June 2001. The median amount of time they spent in the three main areas is also shown. Data are also provided for individual tailrace and forebays. $\mathrm{N}=$ number of fish. Variables in the same column with a capitalized letter in common indicate that there is no significant $(\mathrm{P}>0.05)$ difference among major areas (tailraces, fishways, forebays). Variables in the same column with a lower case letter in common indicate that there is no significant $(\mathrm{P}>0.05)$ difference within a particular tailrace or forebay.

\begin{tabular}{|c|c|c|c|c|c|c|c|c|c|c|}
\hline \multirow{2}{*}{ Area } & \multirow{2}{*}{$\mathrm{N}$} & \multicolumn{2}{|c|}{ Swimming Speed } & \multicolumn{3}{|c|}{ Energy Use Rate $\left(\mathrm{kcal} \mathrm{kg}^{-1} \mathrm{~h}^{-1}\right)$} & \multirow{2}{*}{ Time $(\mathrm{h})$} & \multicolumn{3}{|c|}{ Energy Used $\left(\mathrm{kcal} \mathrm{kg}^{-1}\right)$} \\
\hline & & $\mathrm{cm} \mathrm{s}^{-1}$ & $\mathrm{BL} \mathrm{s}^{-1}$ & Aerobic & Anaerobic & Total & & Aerobic & Anaerobic & Total \\
\hline \multicolumn{11}{|l|}{ Tailraces } \\
\hline Powerhouse 1 & 22 & $108.0(9.1)^{\mathrm{bc}}$ & $1.43(0.1)^{\mathrm{bc}}$ & $1.31(0.10)^{\mathrm{bc}}$ & $1.65(0.22)^{\mathrm{bc}}$ & $3.00(0.3)^{\mathrm{bc}}$ & & & & \\
\hline Spillway & 41 & $91.5(4.1)^{\mathrm{b}}$ & $1.21(0.1)^{\mathrm{b}}$ & $1.32(0.05)^{\mathrm{b}}$ & $1.05(0.11)^{\mathrm{b}}$ & $2.18(0.15)^{\mathrm{b}}$ & & & & \\
\hline Powerhouse 2 & 49 & $119.2(6.5)^{\mathrm{ac}}$ & $1.58(0.1)^{\mathrm{ac}}$ & $1.39(0.07)^{\mathrm{ac}}$ & $1.86(0.16)^{\mathrm{ac}}$ & $3.26(0.22)^{\mathrm{ac}}$ & & & & \\
\hline Combined & 76 & $106.4(4.2)^{\mathrm{A}}$ & $1.40(0.1)^{\mathrm{A}}$ & $1.27(0.04)^{\mathrm{A}}$ & $1.53(0.10)^{\mathrm{A}}$ & $2.8(0.15)^{\mathrm{A}}$ & $21.1^{\mathrm{A}}$ & $25.5^{\mathrm{A}}$ & $19.3^{\mathrm{A}}$ & $48.1^{\mathrm{A}}$ \\
\hline \multicolumn{11}{|l|}{ Fishways } \\
\hline Combined & 79 & $84.9(4.2)^{\mathrm{B}}$ & $1.13(0.1)^{\mathrm{B}}$ & $1.11(0.05)^{\mathrm{B}}$ & $1.11(0.09)^{\mathrm{B}}$ & $2.22(0.13)^{\mathrm{B}}$ & $5.0^{\mathrm{B}}$ & $5.6^{\mathrm{B}}$ & $4.5^{\mathrm{B}}$ & $11.1^{\mathrm{B}}$ \\
\hline \multicolumn{11}{|l|}{ Forebays } \\
\hline Powerhouse 1 & 35 & $82.5(7.4)^{\mathrm{a}}$ & $1.09(0.1)^{\mathrm{a}}$ & $1.02(0.08)^{\mathrm{a}}$ & $0.79(0.18)^{\mathrm{a}}$ & $1.81(0.26)^{\mathrm{a}}$ & & & & \\
\hline Spillway & 10 & $89.3(13.9)^{\mathrm{a}}$ & $1.17(0.2)^{\mathrm{a}}$ & $1.02(0.53)^{\mathrm{a}}$ & $0.76(1.05)^{\mathrm{a}}$ & $0.78(1.55)^{\mathrm{a}}$ & & & & \\
\hline Powerhouse 2 & 13 & $70.6(10.8)^{\mathrm{a}}$ & $0.96(0.2)^{\mathrm{a}}$ & $0.90(0.12)^{\mathrm{a}}$ & $0.56(0.20)^{\mathrm{a}}$ & $1.46(0.31)^{\mathrm{a}}$ & & & & \\
\hline Combined & 45 & $80.2(6.2)^{\mathrm{B}}$ & $1.06(0.1)^{\mathrm{B}}$ & $1.00(0.07)^{\mathrm{B}}$ & $0.73(0.14)^{\mathrm{B}}$ & $1.73(0.21)^{\mathrm{B}}$ & $0.7^{\mathrm{C}}$ & $0.6^{\mathrm{C}}$ & $0.2^{\mathrm{C}}$ & $0.9^{\mathrm{C}}$ \\
\hline
\end{tabular}



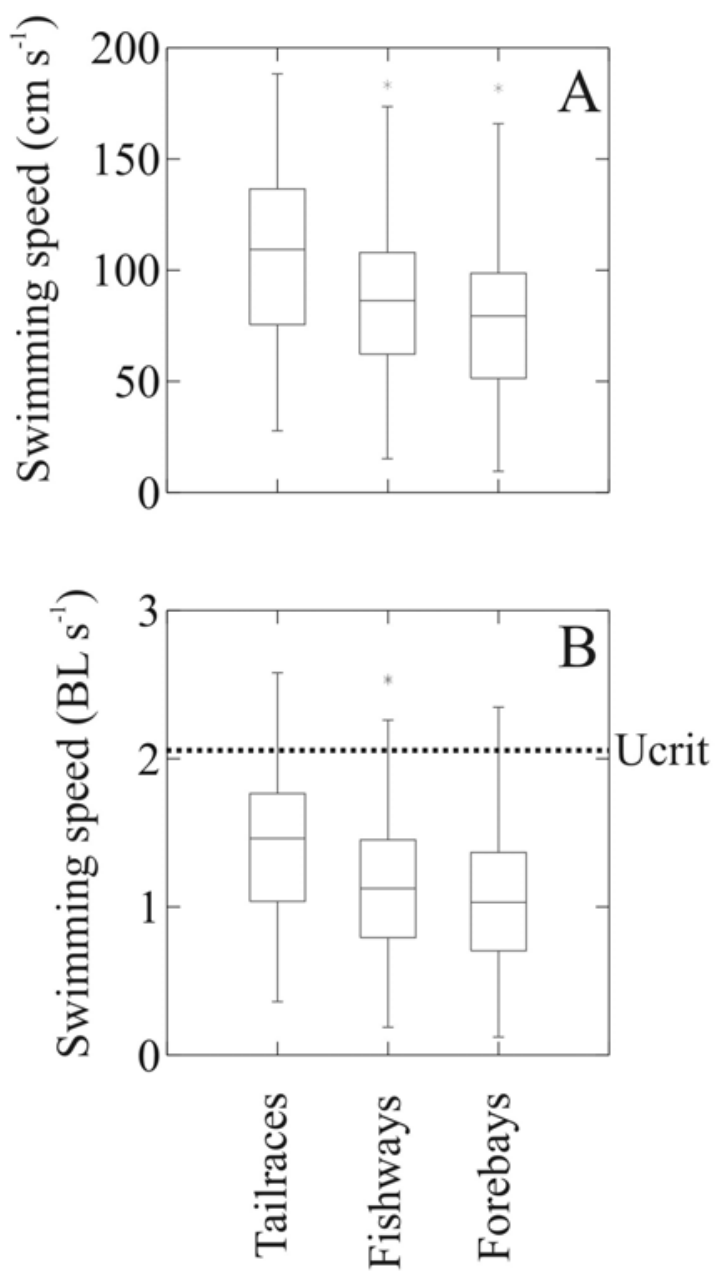

Figure 3.6. Box Plots of Mean Swimming Speeds (in $\mathrm{cm} \mathrm{s}^{-1}$ (Panel A), and BL s${ }^{-1}$ (Panel B)) of 85 Spring Chinook Salmon at Three Different Areas during Passage of Bonneville Dam, April - June, 2001. Boxes indicate the $25^{\text {th }}$ and $75^{\text {th }}$ percentile of data, line inside box indicates median of data. Whiskers indicate the $95 \%$ confidence intervals for the data, asterisks are outliers. Ucrit of Columbia River spring chinook salmon is shown for reference.

Table 3.3. Mean Percentage (and range) of EMG Signals (emitted from an individual transmitter) Collected from Individual Spring Chinook Salmon Passing Bonneville Dam April - June 2001 that Are over Either 70, 80, or 100\% of the Critical Swimming Speed for Spring Chinook Salmon. Also shown is the percentage of signals that are over the highest swimming speed that the fish were calibrated.

\begin{tabular}{||l|c|c|c|c||}
\hline \multirow{2}{*}{ Location } & \multicolumn{4}{|c||}{ Percentage of Swimming Speeds } \\
\cline { 2 - 5 } & $>70 \%$ Ucrit & $>80 \%$ Ucrit & $>100 \%$ Ucrit & $>$ Highest Calibration Speed \\
\hline Tailrace & $44(2-90)$ & $38(1-88)$ & $26(0-72)$ & $20(0-64)$ \\
\hline Fishway & $33(1-91)$ & $26(1-86)$ & $16(0-66)$ & $11(0-57)$ \\
\hline Forebay & $33(4-88)$ & $23(2-86)$ & $14(1-66)$ & $10(1-69)$ \\
\hline
\end{tabular}



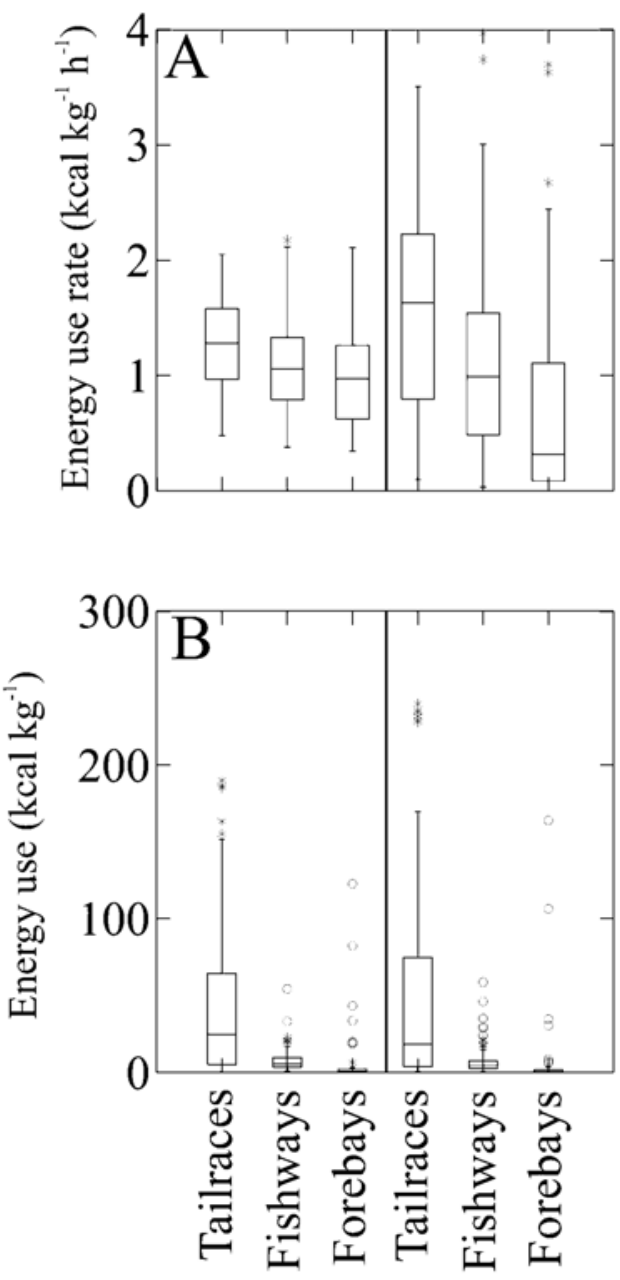

Figure 3.7. Box Plots of Mean Energy Use Rates (Panel A) and Energy Used (Panel B) by Spring Chinook Salmon at Three Different Areas during Passage of Bonneville Dam, April - June, 2001. The left side of each panel shows values for aerobic energy use, while the right side shows values for anaerobic energy use. Boxes indicate the $25^{\text {th }}$ and $75^{\text {th }}$ percentile of data, while the line inside the box indicates the median of the data. Whiskers indicate the $95 \%$ confidence intervals for the data, asterisks are outliers. One outlier $\left(763 \mathrm{kcal} \mathrm{kg}^{-1}\right)$ was removed from the aerobic energy use data (Panel B) for the tailrace and one outlier (992 kcal $\mathrm{kg}^{-1}$ ) was removed from the anaerobic energy use data (Panel B) for the tailrace. 

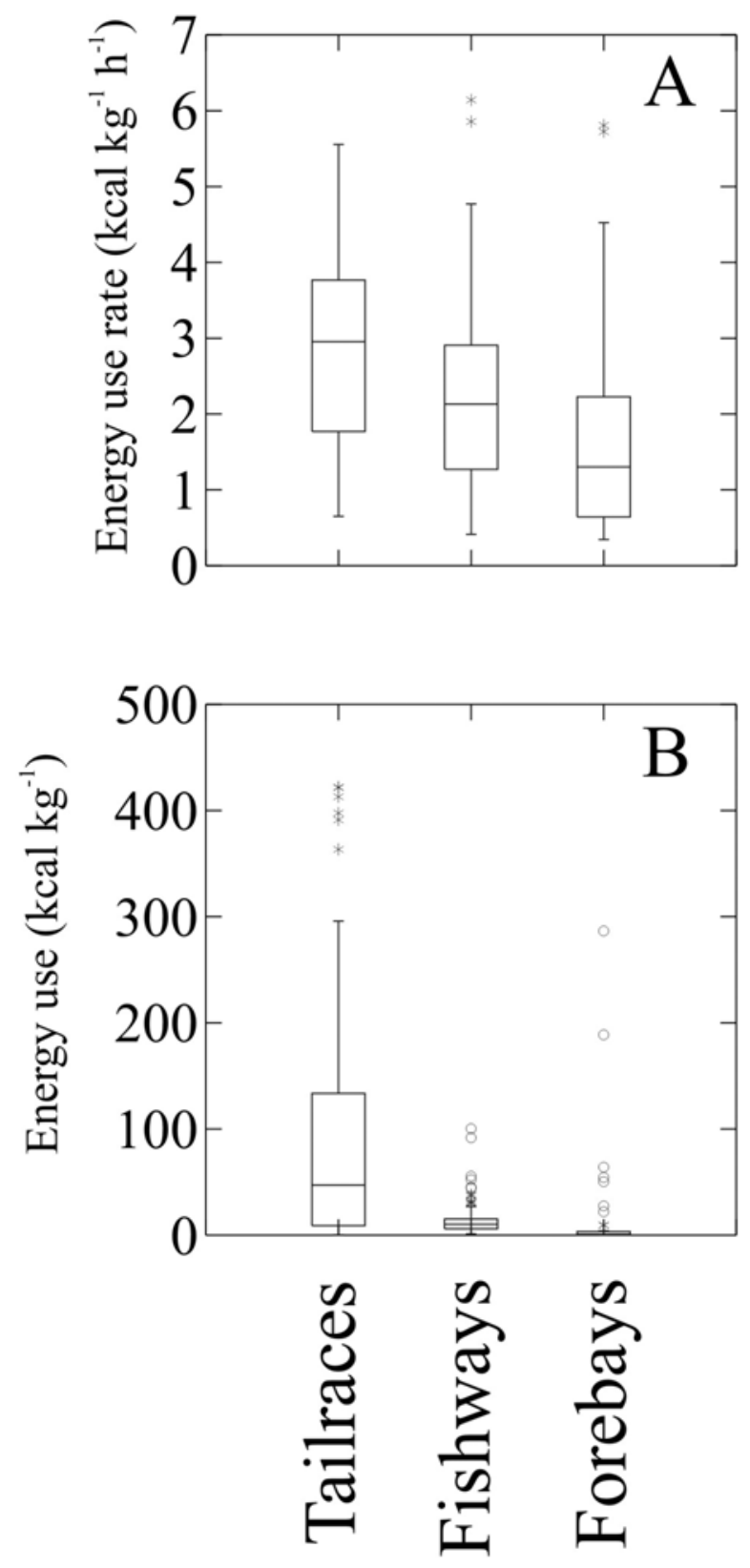

Figure 3.8. Box Plots of Total (aerobic and anaerobic combined) Energy Use Rates (Panel A) and Total (aerobic and anaerobic combined) Energy Used (Panel B) by Spring Chinook Salmon at Three Different Areas during Passage of Bonneville Dam, April - June, 2001. Boxes indicate the $25^{\text {th }}$ and $75^{\text {th }}$ percentile of data, line in box is median of data. Whiskers indicate $95 \%$ confidence intervals, and asterisks are outliers. For purposes of graphing, one outlier of $1,755 \mathrm{kcal}$ was removed from the energy use data (Panel B) for the tailrace. 


\subsubsection{Energy Used}

The energy used (i.e., $\mathrm{kcal} \mathrm{kg}^{-1}$ ) by spring chinook salmon while migrating past Bonneville Dam was primarily expended in the tailraces (Figure 3.7 and 3.8). Eighty-one percent of the median energy used by spring chinook salmon passing the dam was used in the tailrace $(48.1 \mathrm{kcal})$, while only $18 \%$ was used in the fishways $(11.1 \mathrm{kcal})$ and $1.5 \%$ was used in the forebays $(0.9 \mathrm{kcal})$. The total energy that fish used was significantly different among the three areas of dam passage (Table 3.2; Figure 3.8). Similar trends in differences were observed for aerobic and anaerobic energy use (Table 3.2).

Although the median energy (50th percentile) used to pass the tailraces was $48.1 \mathrm{kcal}$ (Table 3.2), an additional $41 \%$ of the fish (i.e., the $90^{\text {th }}$ percentile) used up to $\sim 300 \mathrm{kcal}$ to pass the tailraces, suggesting the energy use data were highly skewed (Figure 3.9). Similar results occurred in the forebays where the median energy use was $0.9 \mathrm{kcal}$ and the $90^{\text {th }}$ percentile was $\sim 50 \mathrm{kcal}$. The data were also skewed, albeit to a lesser degree, in the fishways where the median was $11.1 \mathrm{kcal}$ as compared to the $90^{\text {th }}$ percentile at $\sim 40 \mathrm{kcal}$ (Figure 3.9).

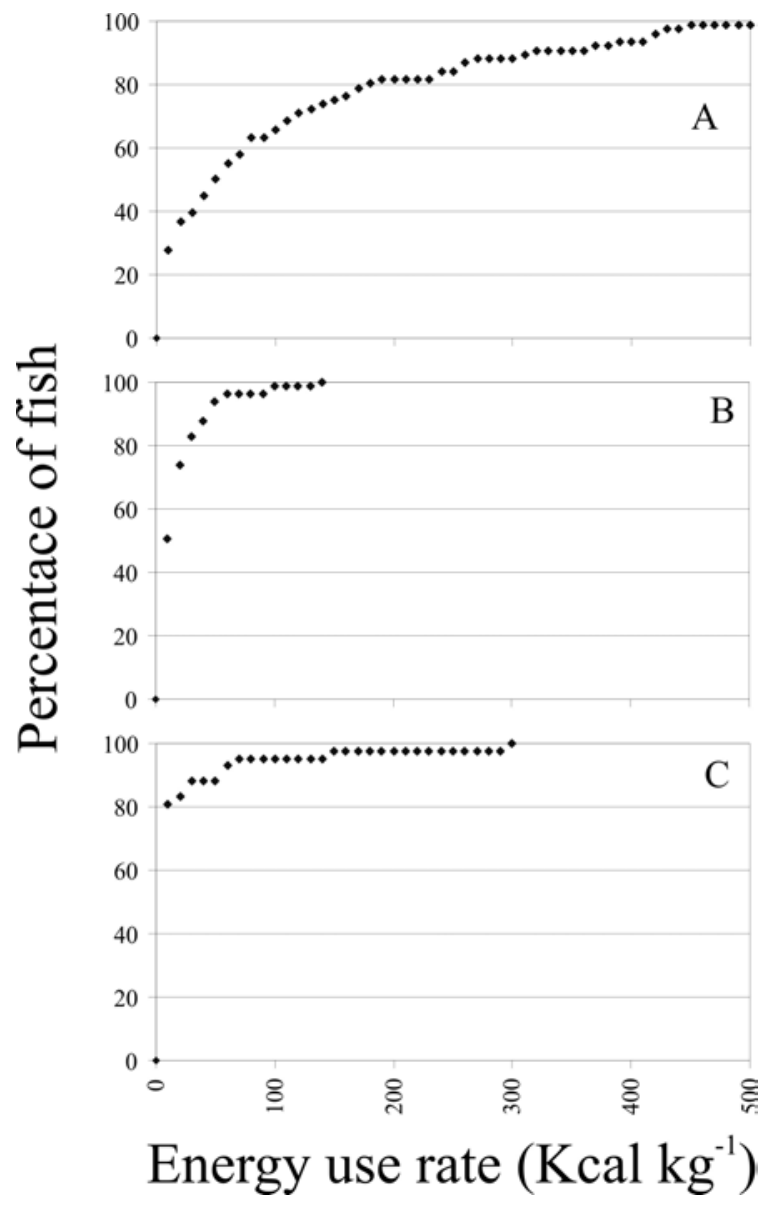

Figure 3.9. Percent Cumulative Distribution of Total (aerobic and anaerobic combined) Energy Used by Spring Chinook Salmon to Pass Three Areas of Bonneville Dam (A=tailraces, B=fishways, $\mathrm{C}=$ forebays) April - June 2001. For purposes of graphing, one outlier of 1,755 kcal was removed from the energy use data for the tailrace (Panel A). 


\subsubsection{Comparisons within Tailraces and Forebays}

\subsubsection{Tailraces}

Within the tailraces, the highest swimming speeds were observed in the tailrace of Powerhouse 2 (Table 3.2; Figure 3.10); mean swimming speeds there $\left(1.58 \mathrm{BL} \mathrm{s}^{-1}\right)$ were $31 \%$ faster than mean swimming speeds in the tailrace of the spillway $\left(1.21 \mathrm{BL} \mathrm{s}^{-1}\right.$; significantly different) and $10 \%$ faster than values in the tailrace of Powerhouse 1 (1.43 $\mathrm{BL} \mathrm{s}^{-1}$; not significantly different). There was no significant difference in the swimming speeds through Powerhouse 1 and the spillway (Table 3.2). Interestingly, daily average discharge through Powerhouse 2 was consistently higher than through Powerhouse 1 and over the spillway at all times during the study (Figure 1.4).
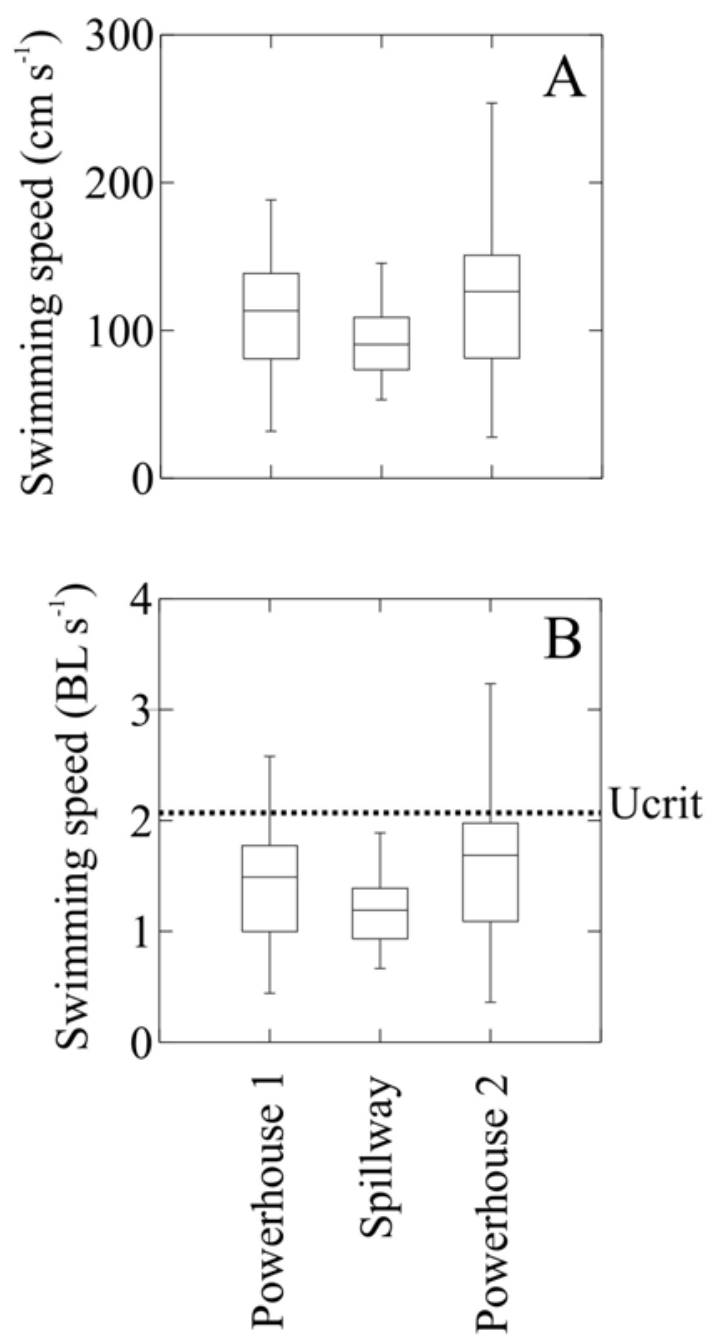

Figure 3.10. Box Plots of Mean Swimming Speeds (in $\mathrm{cm} \mathrm{s}^{-1}$ (Panel A), and BL s $\mathrm{s}^{-1}$ (Panel B)) of 76 Spring Chinook Salmon in Three Different Tailraces during Passage of Bonneville Dam, April - June, 2001. Boxes indicate the $25^{\text {th }}$ and $75^{\text {th }}$ percentile of data, line in box is median of data. Whiskers indicate 95\% confidence intervals for the data. Ucrit (critical swimming speed) measured on Columbia River spring chinook salmon in 2000 is shown for reference. 
The mean rates of energy used (total aerobic and anaerobic) by spring chinook salmon were significantly higher in the tailrace of Powerhouse $2\left(3.26 \mathrm{kcal} \mathrm{kg}^{-1} \mathrm{~h}^{-1}\right)$ than in the spillway tailrace $(2.18$ $\mathrm{kcal} \mathrm{kg}^{-1} \mathrm{~h}^{-1}$; Table 3.2; Figures 3.11 and 3.12). Despite the large differences in the daily average discharge between the two powerhouses (Figure 1.4), there was only a $9 \%$ difference in energy use rates, which was not significantly different. There was also no significant difference in total energy use rates in the spillway and Powerhouse 1 tailraces. Both aerobic and anaerobic energy use rates showed the same trends as the total energy use rate data (Figure 3.11). The exception was that the differences in anaerobic energy use rates approached significance $(\mathrm{P}=0.063)$ between the Powerhouse 1 and spillway tailraces, with anaerobic rates being $77 \%$ higher in the Powerhouse 1 tailrace than in the spillway tailrace.
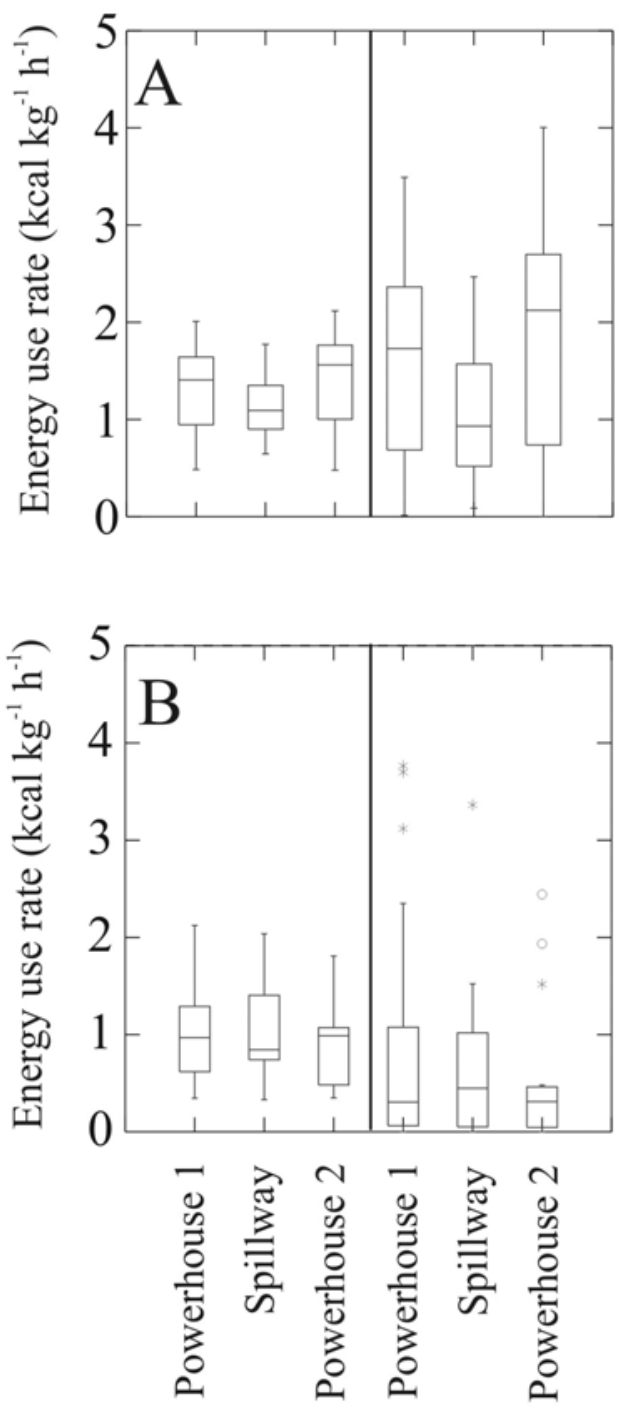

Figure 3.11. Box Plots of Energy Use Rates in Three Different Tailraces (Panel A) and Three Different Forebays (Panel B) by Spring Chinook Salmon as They Passed Bonneville Dam, April June, 2001. The left side of each panel shows values for aerobic energy use, while the right side shows values for anaerobic energy use. Boxes indicate the $25^{\text {th }}$ and $75^{\text {th }}$ percentile of data; line in box indicates median. Whiskers indicate $95 \%$ confidence intervals for the data, asterisks are outliers. 

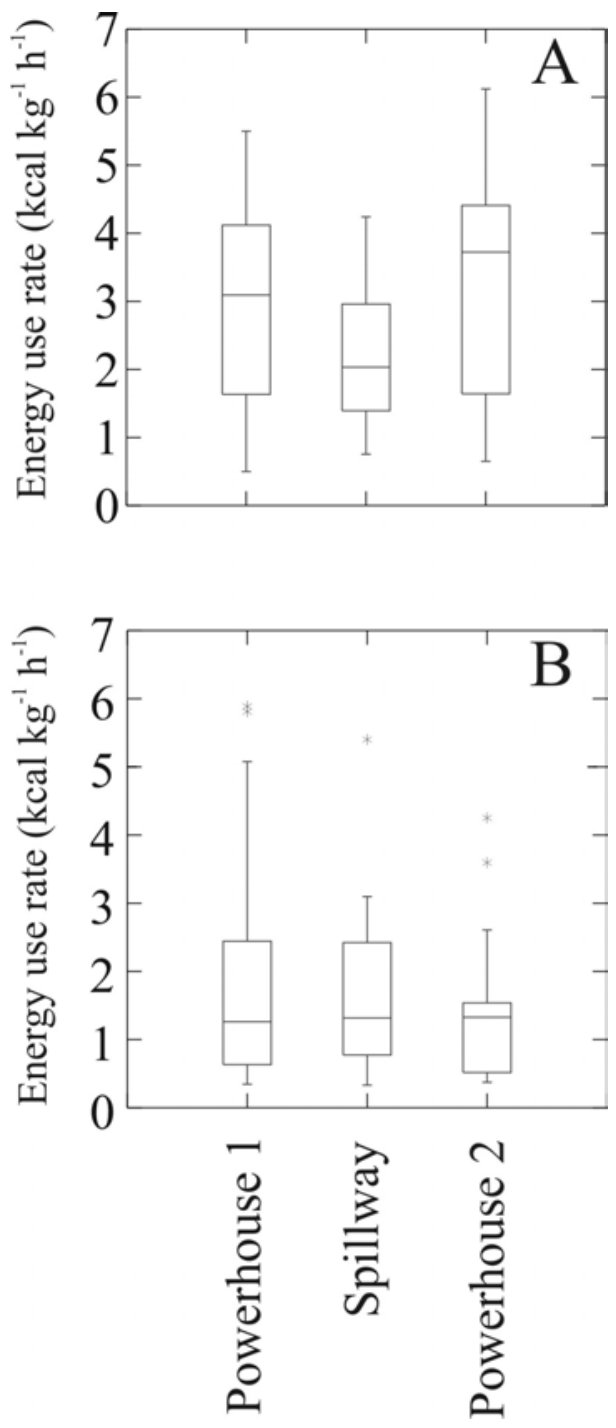

Figure 3.12. Box Plots of Total (aerobic and anaerobic combined) Energy Use Rates in Three Different Tailraces (Panel A) and Three Different Forebays (Panel B) by Spring Chinook Salmon as They Passed Bonneville Dam April - June, 2001. Boxes indicate the $25^{\text {th }}$ and $75^{\text {th }}$ percentile of data, line inside box indicates median of the data. Whiskers indicate the $95 \%$ confidence intervals for the data, asterisks are outliers.

\subsubsection{Forebays}

There was no significant difference in swimming speed among the three forebays (Table 3.2, Figure 3.13). There was also no significant difference in aerobic, anaerobic, or total energy use rates among the three forebays (Figures 3.11 and 3.12). 

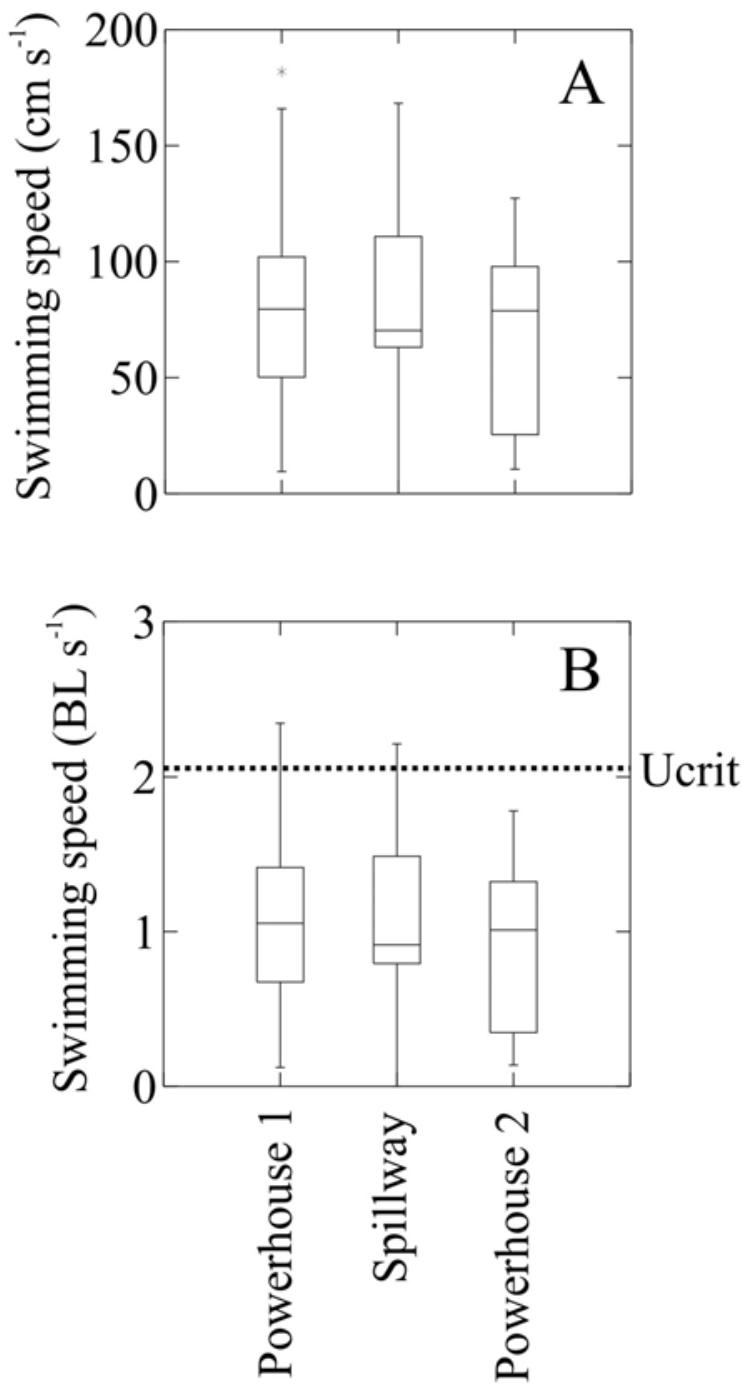

Figure 3.13. Box Plots of Mean Swimming Speeds (in $\mathrm{cm} \mathrm{s}^{-1}$ (Panel A), and BL s${ }^{-1}$ (Panel B)) of 45 Spring Chinook Salmon in Three Different Forebays during Passage of Bonneville Dam, April - June, 2001. Boxes indicate the $25^{\text {th }}$ and $75^{\text {th }}$ percentile of data, while the line inside the box indicates the median of the data. Whiskers indicate the $95 \%$ confidence intervals for the data, asterisks are outliers. Ucrit (critical swimming speed) measured on Columbia River spring chinook salmon in 2000 is shown for reference.

\subsubsection{Variables Influencing Activity}

\subsection{Diel Period}

The influence of diel period on swimming speed and energy use depended on area. In the forebays, there was no significant difference in either swimming speed or energy use rates between day and night (Tables 3.4 and 3.5, Figures 3.14 and 3.15). This was true not only for total (aerobic and anaerobic combined) energy use rates, but for both aerobic and anaerobic energy use rates. 
Table 3.4. Swimming Speeds during Day and Night of Spring Chinook Salmon Passing Bonneville Dam, April - June 2001. Variables in the same row with a letter in common indicate that there is no significant $(\mathrm{P}>0.05)$ difference between day and night.

\begin{tabular}{|c|c|c|c|c||}
\hline \multirow{2}{*}{ Area } & \multicolumn{2}{|c|}{ Swimming Speed $\left(\mathrm{cm} \mathrm{s}^{-1}\right)$} & \multicolumn{2}{|c|}{ Swimming Speed $\left(\mathrm{BL} \mathrm{s}^{-1}\right)$} \\
\cline { 2 - 5 } & Day & Night & Day & Night \\
\hline Tailraces & $109.0(4.5)^{\mathrm{a}}$ & $87.6(7.1)^{\mathrm{a}}$ & $1.44(0.1)^{\mathrm{a}}$ & $1.16(0.1)^{\mathrm{a}}$ \\
\hline Forebays & $88.0(6.5)^{\mathrm{a}}$ & $62.4(32.0)^{\mathrm{a}}$ & $1.17(0.9)^{\mathrm{a}}$ & $0.84(0.4)^{\mathrm{a}}$ \\
\hline
\end{tabular}

Table 3.5. Energy Use Rates during Day and Night of Spring Chinook Salmon Passing Bonneville Dam, April - June 2001. Total energy rates are aerobic and anaerobic rates combined. Variables in the same row with a letter in common indicate that there is no significant $(\mathrm{P}>0.05)$ difference between day and night.

\begin{tabular}{|c|c|c|c|c|c|c||}
\hline \multirow{2}{*}{ Area } & \multicolumn{2}{|c|}{ Aerobic } & \multicolumn{2}{c|}{ Anaerobic } & \multicolumn{2}{c||}{ Total } \\
\cline { 2 - 7 } & Day & Night & Day & Night & Day & Night \\
\hline Tailraces & $1.31(0.0)^{\mathrm{a}}$ & $1.12(0.1)^{\mathrm{b}}$ & $1.59(0.1)^{\mathrm{a}}$ & $1.16(0.2)^{\mathrm{a}}$ & $2.91(0.1)^{\mathrm{a}}$ & $2.29(0.3)^{\mathrm{a}}$ \\
\hline Forebays & $1.04(0.5)^{\mathrm{a}}$ & $0.97(0.3)^{\mathrm{a}}$ & $0.85(1.2)^{\mathrm{a}}$ & $1.19(0.7)^{\mathrm{a}}$ & $1.89(1.7)^{\mathrm{a}}$ & $2.15(1.0)^{\mathrm{a}}$ \\
\hline
\end{tabular}

Although there was no significant difference between swimming speeds in tailraces between day (1.44 BL s${ }^{-1}$; Table 3.4, Figure 3.14) and night (1.16 BL s$\left.{ }^{-1}\right)$, there were differences in energy use between these two periods (Table 3.5, Figure 3.15). The aerobic energy use rates of fish in tailraces were significantly higher during the day $\left(1.31 \mathrm{kcal} \mathrm{kg}^{-1} \mathrm{~h}^{-1}\right)$ than during the night $\left(1.12 \mathrm{kcal} \mathrm{kg}^{-1} \mathrm{~h}^{-1}\right)$. There was no significant difference between day and night in either swimming speed, total, or anaerobic energy use rates. However, the alpha for both values approached significance $(\mathrm{P}=0.057$ for swimming speed in $\mathrm{BL} \mathrm{s}^{-1} ; \mathrm{P}=0.056$ for anaerobic and $\mathrm{P}=0.052$ for total energy use rates).

\subsection{Sex}

The sex of the fish did not make a significant contribution to the differences in swimming speed or energy use rates used in any of the three main parts of the dam (tailraces, fishways, or forebays).

\subsection{Project Operations}

There was no significant linear relationship between total energy use rates and the discharge from the tailrace of either the spillway or powerhouse 1 or 2 (Figure 3.16). If any relationship between these two variables exists, it was not a linear relationship. 

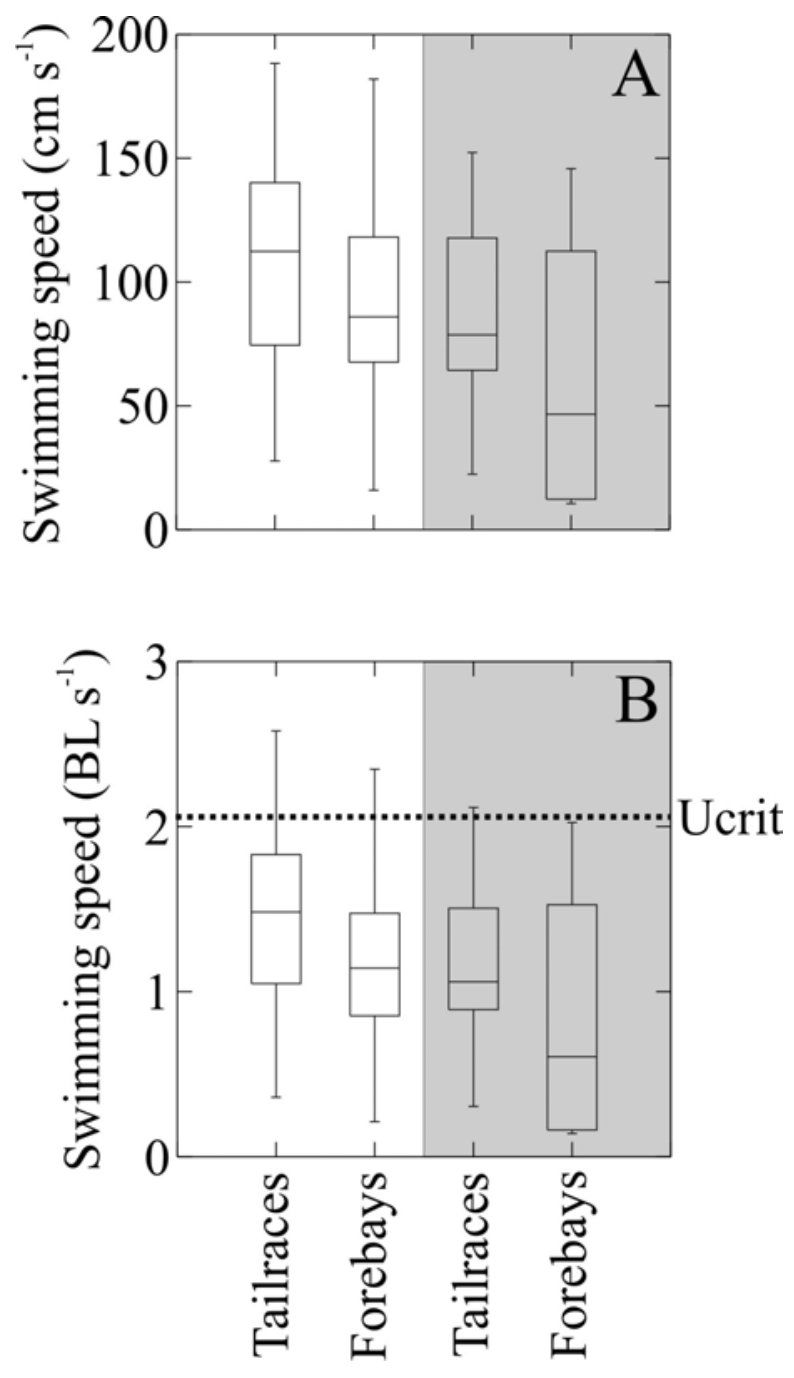

Figure 3.14. Box Plots of Swimming Speed (Panel A) and Energy Use Rates (Panel B) of Spring Chinook Salmon at Three Different Areas of Dam Passage during Both Day and Night (shaded half) at Bonneville Dam, April - June, 2001. Boxes indicate the $25^{\text {th }}$ and $75^{\text {th }}$ percentile of data; line inside box indicates median. Whiskers indicate $95 \%$ confidence intervals for the data. Ucrit (critical swimming speed) measured on Columbia River spring chinook salmon in 2000 is shown for reference. 

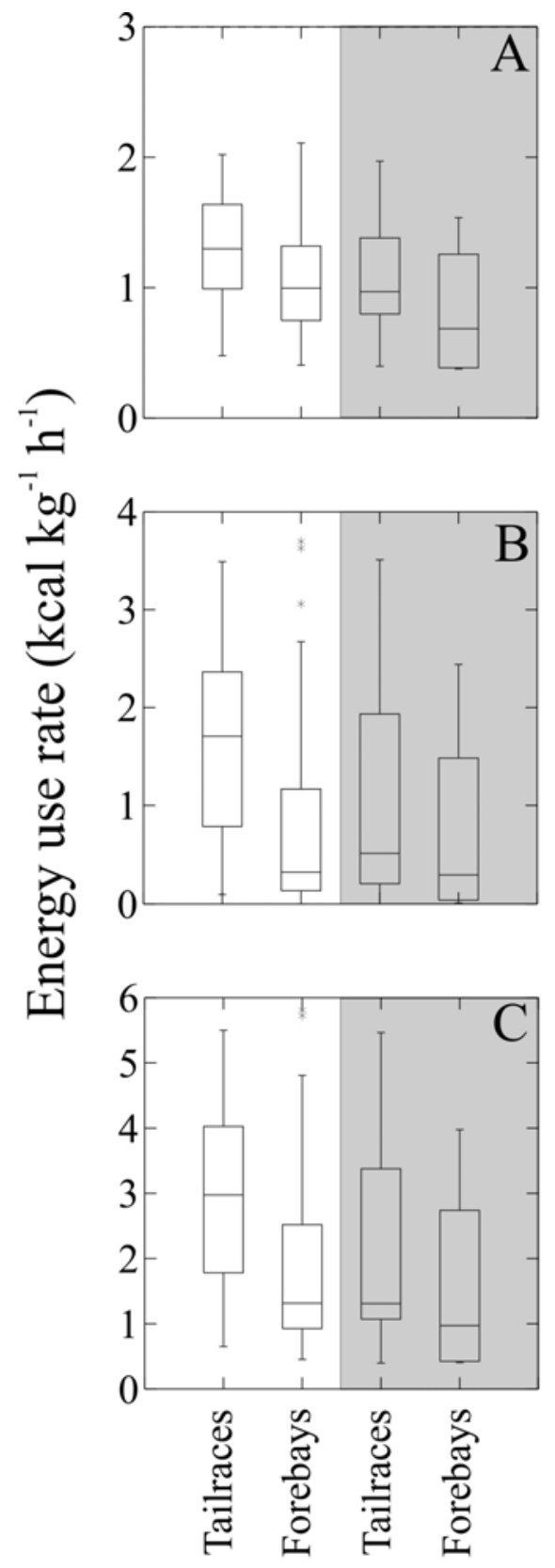

Figure 3.15. Box Plots of Energy Use Rates (aerobic in Panel A, anaerobic in Panel B, and combined in panel C) of Spring Chinook Salmon at Three Different Areas of Dam Passage during both Day and Night (the shaded half of the figures) at Bonneville Dam, April - June, 2001.

Boxes indicate the $25^{\text {th }}$ and $75^{\text {th }}$ percentile of data, line inside box indicates median of data. Whiskers indicate the $95 \%$ confidence intervals for the data, asterisks are outliers. 


\subsubsection{Comparisons within Fishways}

The mean time of the day that fish entered fishways was 14:56 Pacific Standard Time. The mean time that fish exited fishways (14:34) was very similar to the mean time fish entered. All entries and exits of fishways occurred between approximately 05:00 and 22:00 (Figure 3.17).

Of the 79 fish that successfully passed fishways, 55 (70\%) exited on the same day, while the other 24 $(30 \%)$ exited the fishway on a different day than the day they first entered the fishway. Fish that successfully passed the fishway the day they entered, entered a fishway significantly $(\mathrm{P}<0.05)$ earlier $(\mathrm{a}$ mean time of 12:41 vs. a mean time of 17:15) than fish that spent the night in the fishways. Fish that spent the night in fishways exited fishways significantly earlier (a mean time of 9:24) than fish that successfully passed on the same day they entered (a mean time of 16:50). The morning exit of fish is an obvious peak in the histogram of exit times shown in Figure 3.17.

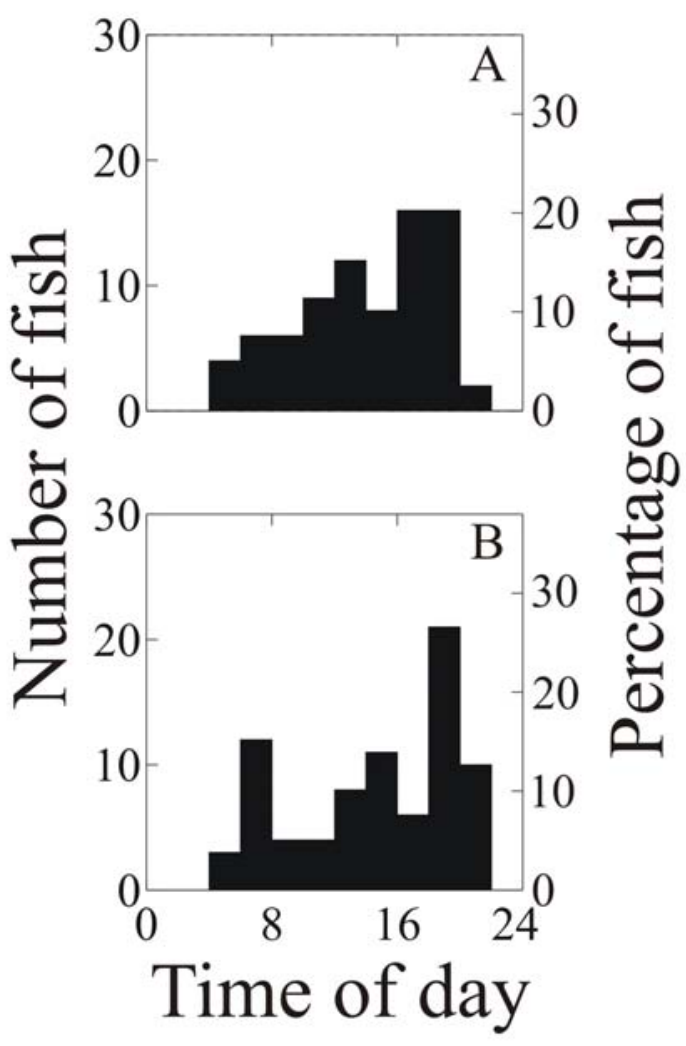

Figure 3.17. The Time of Day when Fish Entered (Panel A) and Exited (Panel B) Fishways during their Successful Passage of Bonneville Dam, April - June, 2001 
Fish that successfully passed fishways spent a median of 5.0 hours and a mean $(\mathrm{SE}=1.1)$ of 9.2 hours in fishways (Figure 3.18). Some fish spent as much as 53 hours in fishways during a successful passage. The amount of time it took a fish to successfully pass a fishway depended on which fishway it passed (Figure 3.19). It took fish significantly less time to pass the Bradford Island fishway (3.10 h, Table 3.6) than the Cascade Island $(5.55 \mathrm{~h})$ or Washington shore $(6.35 \mathrm{~h})$ fishways. There was no significant difference in the amount of time it took fish to pass the Cascade Island and Washington shore fishways.

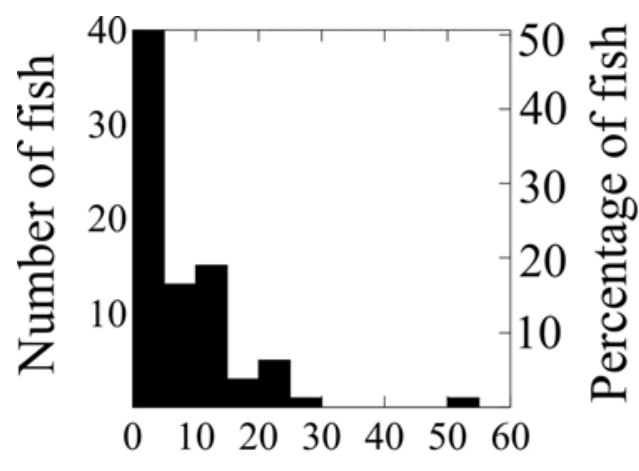

\section{Hours in fishway}

Figure 3.18. A Frequency Histogram Indicating the Number of Hours Spent in a Fishway by Spring Chinook Salmon that Successfully Passed Bonneville Dam, April - June, 2001

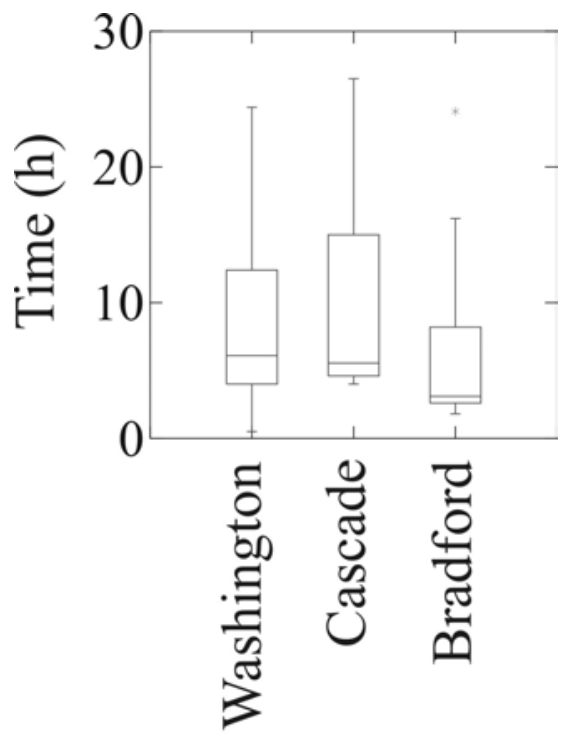

\section{Fishway}

Figure 3.19. Box Plots of Time (h) Spring Chinook Salmon Took to Pass Three Fishways (Washington shore, Cascade Island, and Bradford Island) at Bonneville Dam, April - June, 2001. Boxes indicate the $25^{\text {th }}$ and $75^{\text {th }}$ percentile of data, line in box is median. Whiskers indicate the $95 \%$ confidence intervals for the data, asterisks are outliers. One outlier at 53.2 hours for Washington shore fishway is not shown. 
Table 3.6. Median Energy Used by Spring Chinook Salmon as they Successfully Passed Fishways or Fell Out of Fishways of Bonneville Dam, April - June 2001. The median amount of time they spent in the different fishways is also shown. $\mathrm{N}=$ number of fish. Variables in the same column with a letter in common indicate no significant $(\mathrm{P}>0.05)$ difference between the fishways.

\begin{tabular}{|c|c|c|c|c|c|}
\hline & \multirow[b]{2}{*}{$\mathrm{N}$} & \multirow[b]{2}{*}{ Time (h) } & \multicolumn{3}{|c|}{ Energy Used $\left(\mathrm{kcal} \mathrm{kg}^{-1}\right)$} \\
\hline & & & Aerobic & Anaerobic & Total \\
\hline \multicolumn{6}{|l|}{ Successful passage } \\
\hline Washington & 34 & $6.35^{\mathrm{a}}$ & $6.33^{\mathrm{ab}}$ & $4.90^{\mathrm{a}}$ & $11.89^{\mathrm{ab}}$ \\
\hline Cascade & 8 & $5.55^{\mathrm{a}}$ & $7.45^{\mathrm{b}}$ & $8.05^{\mathrm{a}}$ & $15.50^{\mathrm{b}}$ \\
\hline Bradford & 37 & $3.10^{\mathrm{b}}$ & $3.75^{\mathrm{a}}$ & $4.00^{\mathrm{a}}$ & $7.97^{\mathrm{a}}$ \\
\hline \multicolumn{6}{|c|}{ Unsuccessful passage (fallout) } \\
\hline Washington & 19 & $0.52^{\mathrm{a}}$ & $0.71^{\mathrm{a}}$ & $0.80^{\mathrm{a}}$ & $1.51^{\mathrm{a}}$ \\
\hline Cascade & 5 & $0.61^{\mathrm{a}}$ & $1.10^{\mathrm{a}}$ & $1.81^{\mathrm{a}}$ & $2.92^{\mathrm{a}}$ \\
\hline Bradford & 13 & $0.38^{\mathrm{a}}$ & $0.52^{\mathrm{a}}$ & $0.39^{\mathrm{a}}$ & $0.92^{\mathrm{a}}$ \\
\hline
\end{tabular}

\subsubsection{Swimming Speed and Energetics}

Some fish behavior appeared to be fairly uniform among the three different fishways at Bonneville Dam. Although there were differences in the amount of time spent in the fishways, there was no significant difference among the three fishways in either swimming speed (Figure 3.20) or energy use rates (Table 3.7, Figure 3.21). However, due to the different amounts of time fish spent in the fishways, there were differences in the amounts of energy used in the three fishways (Figure 3.22; Table 3.6). The amount of aerobic $\left(7.45 \mathrm{kcal} \mathrm{kg}^{-1}\right)$ and total energy used $\left(15.5 \mathrm{kcal} \mathrm{kg}^{-1}\right)$ in the Cascade Island fishway was significantly higher than that used in the Bradford Island fishway (aerobic $=3.75 \mathrm{kcal} \mathrm{kg}^{-1}$, total $=$ $7.97 \mathrm{kcal} \mathrm{kg}^{-1}$ ). There were no significant differences between the aerobic or total energy used in the Washington shore fishway and the other two fishways. There were also no significant differences among the three fishways in anaerobic energy used.

\subsubsection{Fallout}

Several spring chinook salmon ( 25 of 79 , or $32 \%$ ) entered fishways more than one time and fell back out of fishways. Some fish entered and fell back out of fishways up to 21 times. However, the mean number of fallouts for each fish was $3.3(\mathrm{SE}=0.8)$ while the median was 2.0.

The total amount of time fish spent in fishways (Figure 3.22) during unsuccessful entries was a median of 0.48 hours (range $0.016-24.82$ hours; the median is shown since data are not normally distributed). This is $9.6 \%$ of the median time it took fish to successfully pass a fishway. There was no significant difference among fishways in the amount of time fish spent during fallout events (Table 3.6; medians ranged from $0.38 \mathrm{~h}$ in the Bradford Island fishway to $0.61 \mathrm{~h}$ in the Cascade Island Fishway). 

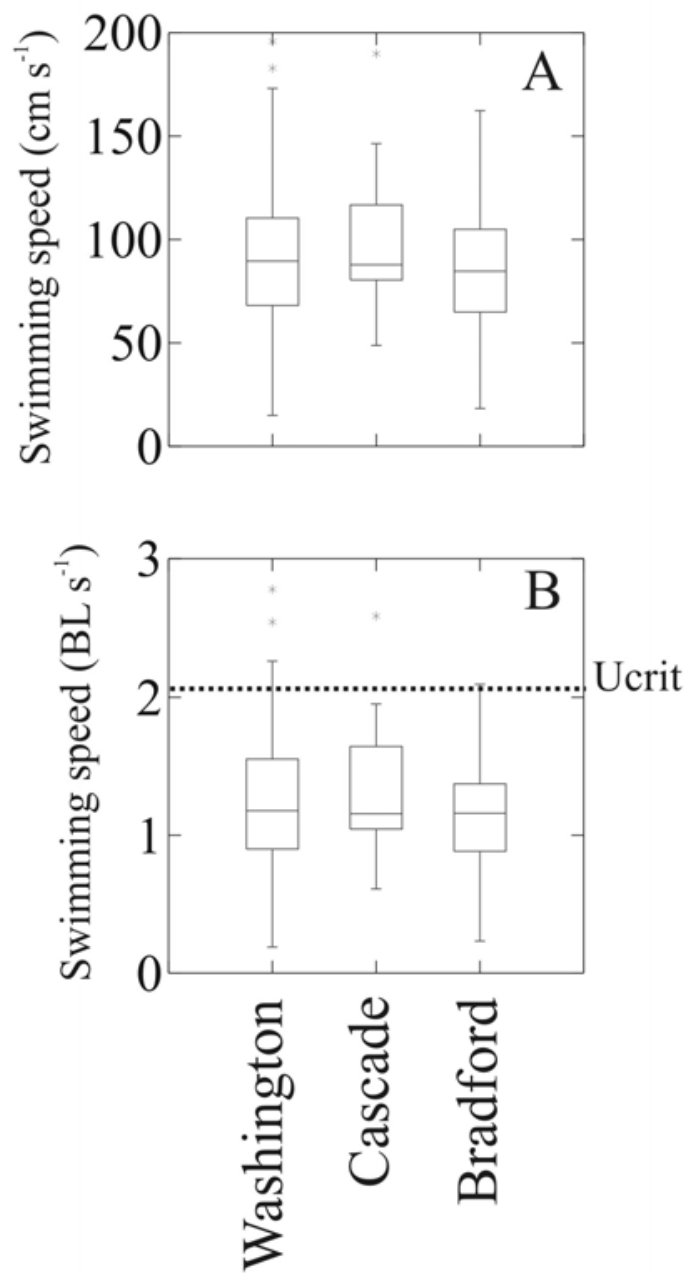

Figure 3.20. Box Plots of Swimming Speeds (in $\mathrm{cm} \mathrm{s}^{-1}$ in Panel A and in BL s${ }^{-1}$ in Panel B) of Spring Chinook Salmon in the Washington Shore, Cascade Island, and Bradford Island Fishways as They Passed Bonneville Dam, April - June, 2001. Swimming speeds are related to critical swimming speed in panel $\mathrm{B}$. Boxes indicate $25^{\text {th }}$ and $75^{\text {th }}$ percentile of data; line in box is median. Whiskers show 95\% confidence intervals, asterisks are outliers. 
Table 3.7. Mean Swimming Speeds $( \pm \mathrm{SE})$ and Energy Use Rates $( \pm \mathrm{SE})$ of Spring Chinook Salmon as they Successfully Passed Three Different Fishways or Fell out of Fishways, April - June 2001. $\mathrm{N}=$ number of fish. Variables in the same column with a letter in common indicate no significant $(\mathrm{P}>0.05)$ difference among fishways.

\begin{tabular}{|l|c|c|c|c|c|c||}
\hline \multirow{2}{*}{ Area } & \multirow{2}{*}{$\mathrm{N}$} & \multicolumn{2}{|c|}{ Swimming Speed } & \multicolumn{3}{c|}{ Energy Use Rate $\left(\mathrm{kcal} \mathrm{kg}^{-1} \mathrm{~h}^{-1}\right)$} \\
\cline { 3 - 7 } & & $\mathrm{cm} \mathrm{s}^{-1}$ & $\mathrm{BL} \mathrm{s}^{-1}$ & Aerobic & Anaerobic & Total \\
\hline Successful Passage & 34 & $81.3(7.3)^{\mathrm{a}}$ & $1.08(0.1)^{\mathrm{a}}$ & $1.06(0.1)^{\mathrm{a}}$ & $1.09(0.2)^{\mathrm{a}}$ & $2.15(0.2)^{\mathrm{a}}$ \\
\hline Washington & 8 & $100.3(14.2)^{\mathrm{a}}$ & $1.33(0.2)^{\mathrm{a}}$ & $1.32(0.2)^{\mathrm{a}}$ & $1.43(0.4)^{\mathrm{a}}$ & $2.75(0.5)^{\mathrm{a}}$ \\
\hline Cascade & 37 & $85.1(5.5)^{\mathrm{a}}$ & $1.12(0.1)^{\mathrm{a}}$ & $1.12(0.1)^{\mathrm{a}}$ & $1.10(0.1)^{\mathrm{a}}$ & $2.22(0.2)^{\mathrm{a}}$ \\
\hline Bradford & 37 & & & \\
\hline Unsuccessful Passage (fallout $)$ & 19 & $121.7(12.4)^{\mathrm{a}}$ & $1.63(0.2)^{\mathrm{a}}$ & $1.43(0.1)^{\mathrm{a}}$ & $1.80(0.3)^{\mathrm{a}}$ & $3.24(0.4)^{\mathrm{a}}$ \\
\hline Washington & 19 & $119.8(11.3)^{\mathrm{a}}$ & $1.62(0.2)^{\mathrm{a}}$ & $1.58(0.1)^{\mathrm{a}}$ & $2.09(0.5)^{\mathrm{a}}$ & $3.67(0.7)^{\mathrm{a}}$ \\
\hline Cascade & 5 & $86.9(8.2)^{\mathrm{a}}$ & $1.14(0.1)^{\mathrm{a}}$ & $1.17(0.1)^{\mathrm{a}}$ & $0.99(0.2)^{\mathrm{a}}$ & $2.16(0.3)^{\mathrm{a}}$ \\
\hline Bradford & 13 &
\end{tabular}




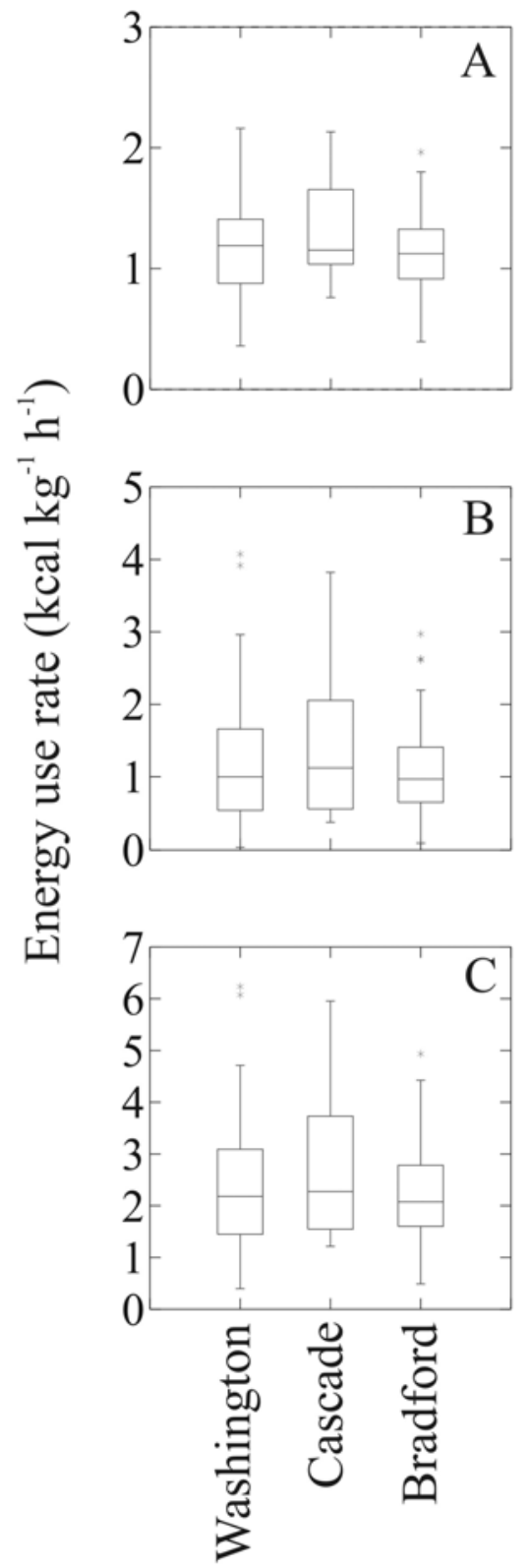

Fishway

Figure 3.21 Box Plots of Energy Use Rates of Spring Chinook Salmon in Washington Shore, Cascade Island, and Bradford Island Fishways as They Passed Bonneville Dam, April - June, 2001. Aerobic energy use rates are shown in panel A, anaerobic rates in panel B, and total rates in panel C. Boxes indicate the $25^{\text {th }}$ and $75^{\text {th }}$ percentile of data; line inside box indicates median. Whiskers indicate $95 \%$ confidence intervals, outliers are shown as asterisks. 

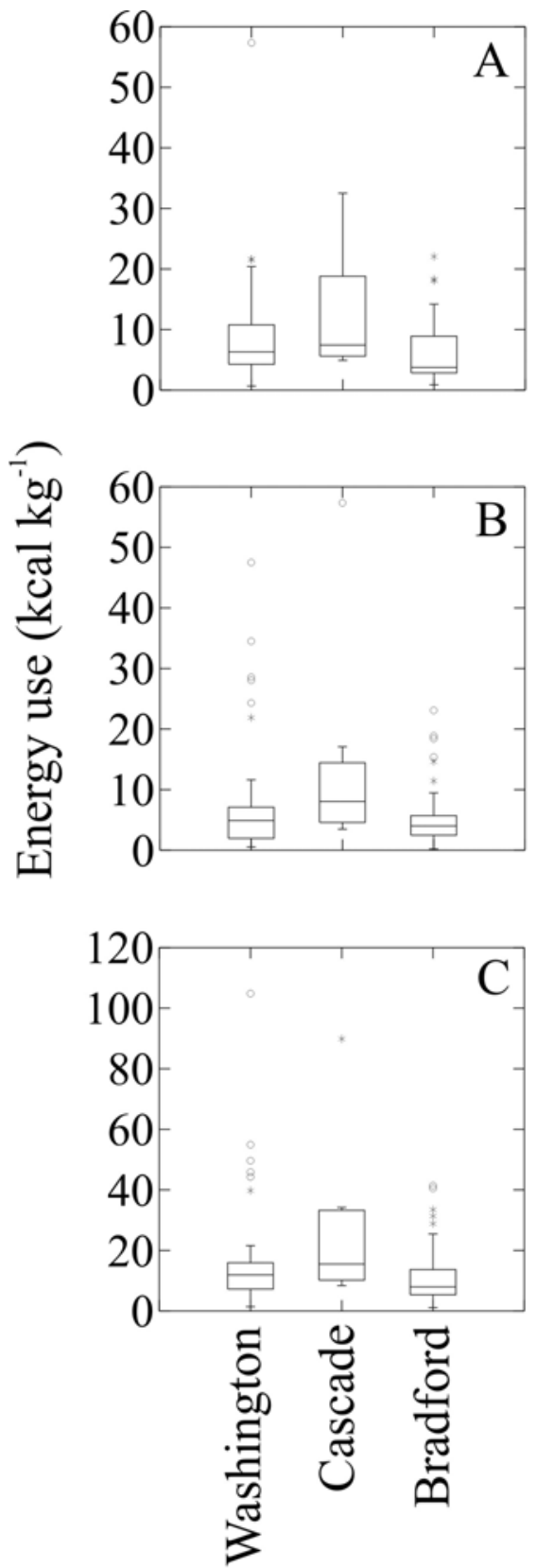

\section{Fishway}

Figure 3.22. Box Plots of Energy Use by Spring Chinook Salmon in Three Different Fishways (Washington Shore, Cascade Island, and Bradford Island) as They Passed Bonneville Dam, April - June, 2001. Aerobic energy use is shown in panel A, anaerobic use in panel B, and total use in panel $\mathrm{C}$. Boxes indicate the $25^{\text {th }}$ and $75^{\text {th }}$ percentile of data; line inside box indicates median. Whiskers indicate $95 \%$ confidence intervals, outliers are shown as asterisks. 


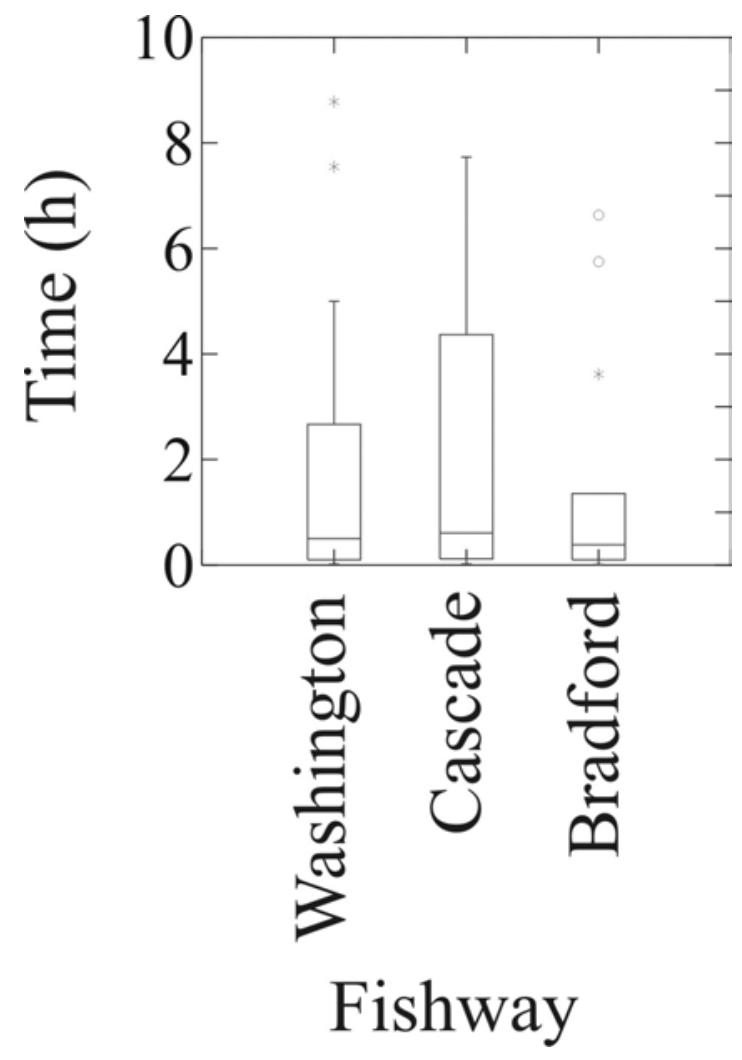

Figure 3.23. Plots of the Amount of Time (h) Spring Chinook Salmon Spent in Three Different Fishways During Fallout (Washington Shore, Cascade Island, and Bradford Island) as They Attempted to Pass Bonneville Dam, April - June, 2001. Boxes indicate the $25^{\text {th }}$ and $75^{\text {th }}$ percentile of data; line inside box indicates median. Whiskers indicate $95 \%$ confidence intervals, asterisks are outliers. One outlier of 23.7 hours from the Washington shore fishway is not shown.

During fallouts, there was no significant difference among the three fishways in either the swimming speeds, the energy use rates, or the amount of energy used (Figure 3.24, 3.25, and 3.26; Table 3.6, 3.7, and 3.8). However, both swimming speeds and rates of energy use during fallout events were significantly higher than during successful fishway passage. This was true for swimming speeds expressed in $\mathrm{cm} \mathrm{s}^{-1}$ (a mean of $85.0 \mathrm{~cm} \mathrm{~s}^{-1}$ during successful passage and a mean of $109.2 \mathrm{~cm} \mathrm{~s}^{-1}$ during fallout) and $\mathrm{BL} \mathrm{s}^{-1}$ (a mean of $1.12 \mathrm{BL} \mathrm{s}^{-1}$ during successful passage and a mean of $1.46 \mathrm{BL} \mathrm{s}^{-1}$ during fallout). The significant differences were also apparent for energy use rates: aerobic (a mean of $1.12 \mathrm{kcal}$ $\mathrm{kg}^{1} \mathrm{~h}^{1}$ during successful passage and a mean of $1.36 \mathrm{kcal} \mathrm{kg}^{1} \mathrm{~h}^{1}$ during fallout), anaerobic (a mean of 1.13 $\mathrm{kcal} \mathrm{kg}{ }^{1} \mathrm{~h}^{1}$ during successful passage and a mean of $1.56 \mathrm{kcal} \mathrm{kg}^{1} \mathrm{~h}^{1}$ during fallout), and total (a mean of $2.24 \mathrm{kcal} \mathrm{kg}^{1} \mathrm{~h}^{1}$ during successful passage and a mean of $2.92 \mathrm{kcal} \mathrm{kg}^{1} \mathrm{~h}^{1}$ during fallout). 

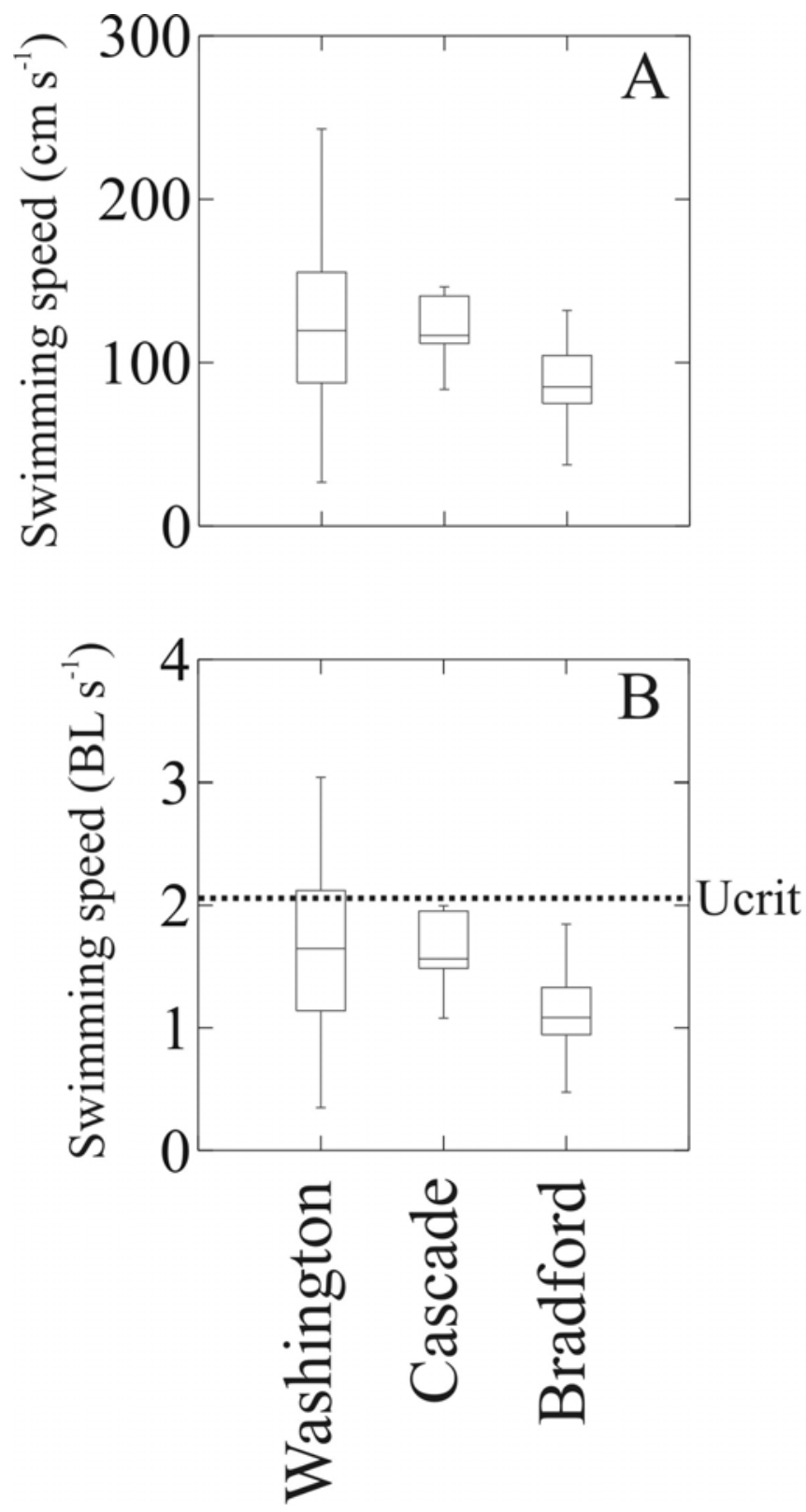

Figure 3.24. Box Plots of Swimming Speeds (in $\mathrm{cm} \mathrm{s}^{-1}$ in panel A and in $\mathrm{BL} \mathrm{s} \mathrm{s}^{-1}$ in panel B) of Spring Chinook Salmon during Fallout in Three Different Fishways (Washington Shore, Cascade Island, and Bradford Island) as they Attempted to Pass Bonneville Dam, April - June, 2001. Swimming speeds are related to critical swimming speed in panel B. Boxes indicate the $25^{\text {th }}$ and $75^{\text {th }}$ percentile of data; line inside box indicates median. Whiskers indicate $95 \%$ confidence intervals. 


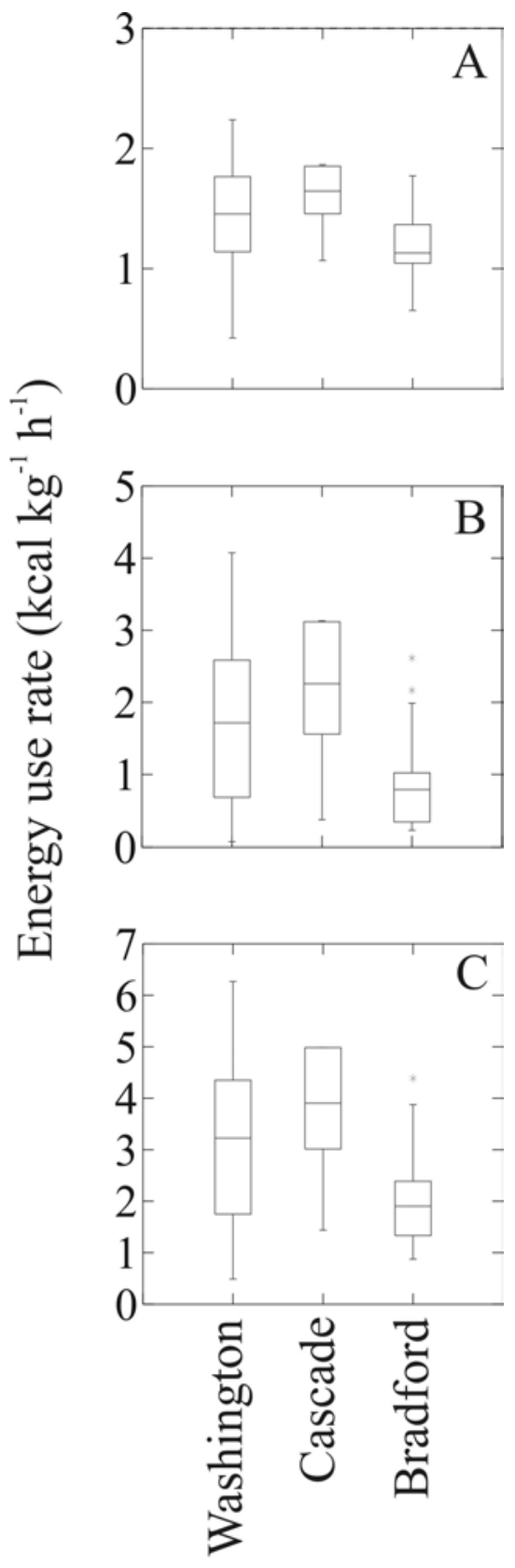

\section{Fishway}

Figure 3.25. Box Plots of Energy Use Rates of Spring Chinook Salmon during Fallout in Three Different Fishways (Washington shore, Cascade Island, and Bradford Island) as They Attempted to Pass Bonneville Dam, April - June, 2001. Aerobic energy use rates are shown in panel A, anaerobic rates in panel $\mathrm{B}$, and total rates in panel $\mathrm{C}$. Boxes indicate the $25^{\text {th }}$ and $75^{\text {th }}$ percentile of data; line inside box indicates median. Whiskers indicate $95 \%$ confidence intervals; outliers are shown by asterisks. 

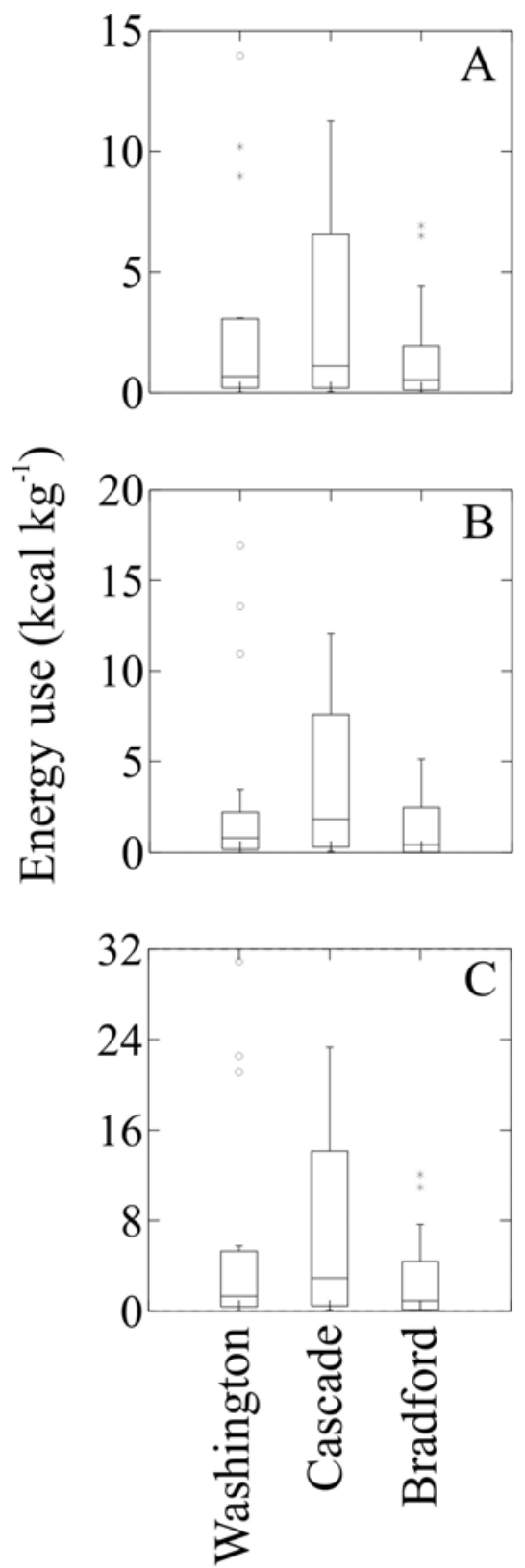

Fishway

Figure 3.26. Box Plots of Energy Use by Spring Chinook Salmon during Fallout in Three Different Fishways (Washington Shore, Cascade Island, and Bradford Island) as They Attempted to Pass Bonneville Dam, April - June, 2001. Aerobic energy use is shown in panel A, anaerobic use in panel B, and total use in panel C. Boxes indicate the $25^{\text {th }}$ and $75^{\text {th }}$ percentile of data; line inside box indicates median. Whiskers indicate $95 \%$ confidence intervals; outliers are shown by asterisks. One outlier of 28.6 is omitted from the aerobic, one outlier of 22.1 is omitted from anaerobic data, and one outlier of 50.7 is omitted from total energy data. 
Table 3.8. Mean Swimming Speeds $( \pm$ SE) and Energy Use Rates $( \pm$ SE) of Spring Chinook Salmon as they Successfully Passed Three Different Fishways during Day or Night, April - June 2001. $N=$ number of fish. Variables in the same row with a letter in common indicate that there is no significant $(\mathrm{P}>0.05)$ difference between day and night.

\begin{tabular}{||r|c|c||}
\hline & Day & Night \\
\hline Swimming Speed & & \\
\hline $\mathrm{cm} \mathrm{s}^{-1}$ & $84.9(3.8)^{\mathrm{a}}$ & $65.4(11.8)^{\mathrm{b}}$ \\
\hline $\mathrm{BL} \mathrm{s}^{-1}$ & $1.12(0.1)^{\mathrm{a}}$ & $0.86(0.2)^{\mathrm{b}}$ \\
\hline Energy Use Rates & & \\
\hline aerobic & $1.12(0.4)^{\mathrm{a}}$ & $0.85(0.1)^{\mathrm{b}}$ \\
\hline anaerobic & $1.10(0.1)^{\mathrm{a}}$ & $0.63(0.2)^{\mathrm{b}}$ \\
\hline total & $2.22(0.1)^{\mathrm{a}}$ & $1.48(0.3)^{\mathrm{b}}$ \\
\hline
\end{tabular}

The amount of time spent by fish during fallout events varied from $8.2 \%$ to $12.3 \%$ of the time that it took fish to successfully pass fishways. These percentages generally reflected the comparative percent of energy used during fallout events (Figure 3.26, Table 3.6). Energy used during fallout attempts was $11.5 \%$ to $18.8 \%$ of the amount of energy used during successful fishway passage. This percentage was highest in the Cascade Island fishway (18.8\%).

\subsubsection{Differences among Section of Fishways in Swim Speed and Energy Use}

The behavior of fish in different sections of fishways (Figures 1.5, 2.2, and 2.3) was examined based on several different parameters - swimming speed, energy use rates, types of energy use, time spent in areas, the amount of energy used, and the energy use per unit length of fishway.

The mean swimming speeds of the fish were well under the critical swimming speed in all fishway parts, with the highest mean being $118 \mathrm{~cm} \mathrm{~s}^{-1}$ in the entrance to the Cascade Island fishway (Table 3.9). However, there were large differences in swimming speed among fishway sections. As would be expected, the slowest swimming speeds were observed in the junction pool in the Washington shore fishway (section 14; mean $66 \mathrm{~cm} \mathrm{~s}^{-1}$ ). However, in a similar junction pool in the Bradford Island fishway, swimming speeds were much higher (section 4; mean $109 \mathrm{~cm} \mathrm{~s}^{-1}$ ) and actually ranked third highest out of all the fishway sections at Bonneville Dam, and highest in the Bradford Island fishway. This indicates that, although this pool was likely designed to provide an area for fish to rest, fish are not using it for that purpose and are instead moving through it quickly. This is substantiated by the relatively short amount of time spent in this section - a median of 0.16 hours or 9.6 minutes (ranking $6^{\text {th }}$ out of 7 parts of the fishway; with a rank of 7 being the shortest amount of time in an area; Table 3.10). For comparison, fish spent over twice as long ( 0.34 hours or 20.4 minutes) in the junction pool of the Washington Shore fishway. 
Table 3.9. Mean Swimming Speeds of Spring Chinook Salmon in Different Sections of Three Different Fishways of Bonneville Dam, April - June 2001. Ranks of swimming speed are also shown (with 1 being the highest swimming speed) both within individual fishways, and among all fishway sections throughout the dam. $\mathrm{N}=$ number of fish. Fishway section numbers correspond to Figures 1.5, 2.2, and 2.3.

\begin{tabular}{|l|c|c|c|c|c|c|}
\hline \multirow{2}{*}{ Fishway } & \multirow{2}{*}{ Section } & \multirow{2}{*}{$\mathrm{N}$} & \multicolumn{2}{|c|}{ Swimming Speed } & \multicolumn{2}{c|}{ Rank } \\
\cline { 4 - 8 } & & & $\mathrm{cm} \mathrm{s}^{-1}$ & $\mathrm{~B} \mathrm{~s}^{-1}$ & Within & Among \\
\hline Bradford & 1 & 6 & 77 & 1.0 & 5 & 12 \\
\hline Bradford & 2 & 15 & 81 & 1.1 & 4 & 11 \\
\hline Bradford & 3 & 14 & 68 & 0.9 & 6 & 16 \\
\hline Bradford & 4 & 19 & 109 & 1.4 & 1 & 3 \\
\hline Bradford & 5 & 26 & 91 & 1.2 & 3 & 10 \\
\hline Bradford & 6 & 14 & 67 & 0.9 & 7 & 17 \\
\hline Bradford & 7 & 34 & 96 & 1.3 & 2 & 7 \\
\hline Cascade & 8 & 7 & 118 & 1.6 & 1 & 1 \\
\hline Cascade & 9 & 8 & 97 & 1.3 & 2 & 5 \\
\hline Washington & 10 & 30 & 99 & 1.3 & 2 & 4 \\
\hline Washington & 11 & 30 & 92 & 1.2 & 5 & 9 \\
\hline Washington & 12 & 5 & 94 & 1.2 & 4 & 8 \\
\hline Washington & 13 & 9 & 75 & 1.0 & 7 & 13 \\
\hline Washington & 14 & 36 & 66 & 0.9 & 9 & 18 \\
\hline Washington & 15 & 18 & 75 & 1.0 & 6 & 14 \\
\hline Washington & 16 & 7 & 70 & 0.9 & 8 & 15 \\
\hline Washington & 17 & 34 & 96 & 1.3 & 3 & 6 \\
\hline Washington & 18 & 25 & 111 & 1.5 & 1 & 2 \\
\hline \hline
\end{tabular}


Table 3.10. Median Amount of Time Spring Chinook Salmon Spent in Different Sections of Three Different Fishways of Bonneville Dam, April - June 2001. Ranks of time spent are also shown (with 1 being the longest amount of time) both within individual fishways, and among all fishway sections throughout the dam. $\mathrm{N}=$ number of fish. Fishway section numbers correspond to Figures 1.5, 2.2, and 2.3.

\begin{tabular}{|l|c|c|c|c|c|}
\hline \multirow{2}{*}{ Fishway } & \multirow{2}{*}{ Section } & \multirow{2}{*}{$\mathrm{N}$} & \multirow{2}{*}{ Hours } & \multicolumn{2}{|c|}{ Ranks } \\
\cline { 5 - 7 } & & & & Within & Among \\
\hline Bradford & 1 & 6 & 0.09 & 7 & 16 \\
\hline Bradford & 2 & 15 & 0.92 & 2 & 4 \\
\hline Bradford & 3 & 14 & 0.97 & 1 & 3 \\
\hline Bradford & 4 & 19 & 0.16 & 6 & 15 \\
\hline Bradford & 5 & 26 & 0.50 & 3 & 8 \\
\hline Bradford & 6 & 14 & 0.41 & 4 & 9 \\
\hline Bradford & 7 & 34 & 0.33 & 5 & 12 \\
\hline Cascade & 8 & 7 & 0.56 & 2 & 7 \\
\hline Cascade & 9 & 8 & 1.89 & 1 & 1 \\
\hline Washington & 10 & 30 & 0.25 & 6 & 13 \\
\hline Washington & 11 & 30 & 0.77 & 2 & 5 \\
\hline Washington & 12 & 5 & 1.09 & 1 & 2 \\
\hline Washington & 13 & 9 & 0.58 & 3 & 6 \\
\hline Washington & 14 & 36 & 0.34 & 5 & 11 \\
\hline Washington & 15 & 18 & 0.06 & 8 & 17 \\
\hline Washington & 16 & 7 & 0.05 & 9 & 18 \\
\hline Washington & 17 & 34 & 0.38 & 4 & 10 \\
\hline Washington & 18 & 25 & 0.19 & 7 & 14 \\
\hline \hline
\end{tabular}

Another section in which swimming speed ranking is higher than may be expected is the exit to the Washington Shore fishway (section 18). It ranks second highest among all fishway areas (Table 3.9). This section is mostly comprised of a long, relatively low water velocity channel. However, manual trackers noted that fish appeared to be swimming very quickly at the lower end of this section, near the exit of the vertical slot weirs. Unfortunately, placement of antennas did not allow this section to be broken up into subsections.

In both fishways (since there are no vertical slot fishways in the Cascade Island Fishway), swimming speeds were remarkably similar in the vertical slot weirs (sections 7 and 17). The mean swimming speeds 
in both sections were $96 \mathrm{~cm} \mathrm{~s}^{-1}$ and $1.3 \mathrm{BL} \mathrm{s}^{-1}$. This fishway type also ranked relatively high for swimming speeds (ranked $2^{\text {nd }}$ highest within the Bradford Island fishway and $3^{\text {rd }}$ highest within the Washington Shore fishway).

The entrances to the Cascade Island and Washington shore fishways also ranked relatively high, at $1^{\text {st }}$ and $4^{\text {th }}$ highest respectively for swimming speeds among all fishway areas, with mean swimming speeds of 118 and $99 \mathrm{~cm} \mathrm{~s}^{-1}$. The A branch entrance to the Bradford Island fishway; however, ranked relatively low in swimming speeds, having a mean swimming speed of $77 \mathrm{~cm} \mathrm{~s}^{-1}$.

The rankings of energy use rates (Table 3.11) in different sections of the fishways generally reflected ranks of swimming speeds. Rankings were exactly the same in both the Bradford Island and Cascade Island fishways, although two sections switched ranks within the Washington shore fishway.

Table 3.11. Mean Energy Use Rates of Spring Chinook Salmon in Different Sections of the Three Fishways of Bonneville Dam, April - June 2001. Ranks of energy use rates are also shown $(1=$ highest) within individual fishways and among all fishway sections throughout the dam. $\mathrm{N}=$ number of fish. Fishway section numbers correspond to Figures 1.5, 2.2, and 2.3. Aerobic, anaerobic, and total (aerobic + anaerobic) energy use rates are shown.

\begin{tabular}{|l|c|c|c|c|c|c|c||}
\hline \multirow{2}{*}{ Fishway } & \multirow{2}{*}{ Section } & \multirow{2}{*}{$\mathrm{N}$} & \multicolumn{2}{|c|}{ Energy Use Rate $\left(\mathrm{kcal} \mathrm{kg}^{-1} \mathrm{~h}^{-1}\right)$} & \multicolumn{2}{c|}{ Ranks } \\
\cline { 5 - 9 } & & Aerobic & Anaerobic & Total & Within & Among \\
\hline Bradford & 1 & 6 & 0.96 & 0.87 & 1.83 & 5 & 13 \\
\hline Bradford & 2 & 15 & 1.04 & 1.01 & 2.04 & 4 & 12 \\
\hline Bradford & 3 & 14 & 0.95 & 0.73 & 1.67 & 6 & 14 \\
\hline Bradford & 4 & 19 & 1.29 & 1.62 & 2.91 & 1 & 2 \\
\hline Bradford & 5 & 26 & 1.19 & 1.23 & 2.42 & 3 & 10 \\
\hline Bradford & 6 & 14 & 0.92 & 0.67 & 1.60 & 7 & 15 \\
\hline Bradford & 7 & 34 & 1.25 & 1.39 & 2.65 & 2 & 7 \\
\hline Cascade & 8 & 7 & 1.52 & 1.90 & 3.42 & 1 & 1 \\
\hline Cascade & 9 & 8 & 1.29 & 1.40 & 2.69 & 2 & 5 \\
\hline Washington & 10 & 30 & 1.28 & 1.48 & 2.77 & 2 & 4 \\
\hline Washington & 11 & 30 & 1.19 & 1.33 & 2.52 & 5 & 9 \\
\hline Washington & 12 & 5 & 1.24 & 1.30 & 2.53 & 4 & 8 \\
\hline Washington & 13 & 9 & 1.02 & 1.03 & 2.05 & 6 & 11 \\
\hline Washington & 14 & 36 & 0.89 & 0.43 & 1.32 & 9 & 18 \\
\hline Washington & 15 & 18 & 1.00 & 0.54 & 1.54 & 7 & 16 \\
\hline Washington & 16 & 7 & 0.96 & 0.55 & 1.51 & 8 & 17 \\
\hline Washington & 17 & 34 & 1.25 & 1.42 & 2.68 & 3 & 6 \\
\hline Washington & 18 & 25 & 1.36 & 1.54 & 2.90 & 1 & 3 \\
\hline
\end{tabular}


Fish generally spent the longest periods of time (Table 3.10) in long sections of the fishway, such as the Bradford Island A and B branches (sections 2 and 3), the upper section of the Cascade fishway (section 9), and two long sections of the Washington shore fishway (sections 11 and 12). However, fish also spent a relatively long period of time in the adult facility (a median of $0.58 \mathrm{~h}$, or $34.8 \mathrm{~min}$.).

Spending long periods of time in sections of the fishway resulted in fish using a relatively large amount of energy in these areas (Table 3.12). One exception is that, although the amount of time spent in the adult facility was in the upper half of the rankings, the amount of energy used in the facility was in the lower half, due to the relatively low swimming speeds and energy use rates there. However, it should be noted that, although the mean swimming speeds in the adult facility were identical to those in section 15 (the junction pool in the Washington shore fishway), the fish used much more anaerobic energy in the adult facility, likely jumping at the false weir. This resulted in the energy use rates in the adult facility being 33\% higher than in the junction pool of the Washington shore fishway.

Table 3.12. Median Energy Used by Spring Chinook Salmon in Different Sections of Three Different Fishways of Bonneville Dam, April - June 2001. Ranks of energy used also shown ( $1=$ highest) both within individual fishways and among all fishway sections. $\mathrm{N}=$ number of fish. Fishway section numbers correspond to Figures 1.5, 2.2, and 2.3.

\begin{tabular}{|l|c|c|c|c|c|c|c||}
\hline \multirow{2}{*}{ Fishway } & \multirow{2}{*}{ Section } & \multirow{2}{*}{$\mathrm{N}$} & \multicolumn{3}{|c|}{ Energy Use (kcal kg-1 } & \multicolumn{2}{c|}{ Ranks } \\
\cline { 4 - 9 } & & & Aerobic & Anaerobic & Total & Within & Among \\
\hline Bradford & 1 & 6 & 0.07 & 0.05 & 0.11 & 7 & 17 \\
\hline Bradford & 2 & 15 & 0.75 & 0.60 & 1.48 & 2 & 6 \\
\hline Bradford & 3 & 14 & 1.03 & 0.63 & 1.53 & 1 & 5 \\
\hline Bradford & 4 & 19 & 0.18 & 0.16 & 0.34 & 5 & 14 \\
\hline Bradford & 5 & 26 & 0.55 & 0.45 & 1.02 & 3 & 9 \\
\hline Bradford & 6 & 14 & 0.22 & 0.04 & 0.32 & 6 & 15 \\
\hline Bradford & 7 & 34 & 0.40 & 0.47 & 0.88 & 4 & 10 \\
\hline Cascade & 8 & 7 & 0.91 & 0.76 & 1.62 & 2 & 4 \\
\hline Cascade & 9 & 8 & 1.92 & 1.38 & 3.24 & 1 & 2 \\
\hline Washington & 10 & 30 & 0.27 & 0.26 & 0.50 & 5 & 11 \\
\hline Washington & 11 & 30 & 0.90 & 0.90 & 1.78 & 2 & 3 \\
\hline Washington & 12 & 5 & 1.71 & 1.78 & 3.62 & 1 & 1 \\
\hline Washington & 13 & 9 & 0.68 & 0.65 & 1.32 & 3 & 7 \\
\hline Washington & 14 & 36 & 0.30 & 0.13 & 0.46 & 6 & 12 \\
\hline Washington & 15 & 18 & 0.07 & 0.03 & 0.12 & 8 & 16 \\
\hline Washington & 16 & 7 & 0.03 & 0.01 & 0.04 & 9 & 18 \\
\hline Washington & 17 & 34 & 0.51 & 0.63 & 1.18 & 4 & 8 \\
\hline Washington & 18 & 25 & 0.17 & 0.17 & 0.37 & 7 & 13 \\
\hline \hline
\end{tabular}


It is obvious that in many cases the energy used in fishway sections is relatively higher in longer sections than in short sections. Thus, energy use was looked at by unit length (Table 3.13). When the data are presented in this manner, two relatively short sections, where a relatively small amount of energy was used, rank highest - the adult facility $\left(5.2 \mathrm{kcal} \mathrm{kg}^{-1} \mathrm{~m}^{-1}\right)$ and the Bradford Island junction pool (3.3 $\mathrm{kcal} \mathrm{kg}^{-1} \mathrm{~h}^{-1}$ ).

Table 3.13. Median Total Energy Used per Meter Length of Fishway by Spring Chinook Salmon in Different Sections of Three Different Fishways of Bonneville Dam, April - June 2001. Ranks of energy use per meter are also shown (with 1 being the highest) both within individual fishways and among all fishway sections throughout the dam. Fishway section numbers correspond to Figures 1.5, 2.2, and 2.3.

\begin{tabular}{|c|c|c|c|c|c|}
\hline \multirow[b]{2}{*}{ Fishway } & \multirow[b]{2}{*}{ Section } & \multirow[b]{2}{*}{ Length (m) } & \multirow{2}{*}{$\begin{array}{c}\text { Total Energy Used } \\
\left(\mathrm{kcal} \mathrm{kg}^{-1} \mathrm{~m}^{-1}\right) \text { per } 100 \mathrm{~m}\end{array}$} & \multicolumn{2}{|c|}{ Ranks } \\
\hline & & & & Within & Among \\
\hline Bradford & 1 & 50 & 0.2 & 7 & 16 \\
\hline Bradford & 2 & 171 & 0.9 & 5 & 12 \\
\hline Bradford & 3 & 200 & 0.8 & 6 & 13 \\
\hline Bradford & 4 & 10 & 3.3 & 1 & 2 \\
\hline Bradford & 5 & 71 & 1.4 & 4 & 10 \\
\hline Bradford & 6 & 15 & 2.1 & 2 & 4 \\
\hline Bradford & 7 & 55 & 1.6 & 3 & 7 \\
\hline Cascade & 8 & 71 & 2.3 & 1 & 3 \\
\hline Cascade & 9 & 258 & 1.3 & 2 & 11 \\
\hline Washington & 10 & 202 & 0.2 & 7 & 15 \\
\hline Washington & 11 & 115 & 1.5 & 4 & 8 \\
\hline Washington & 12 & 172 & 1.5 & 5 & 9 \\
\hline Washington & 13 & 26 & 5.2 & 1 & 1 \\
\hline Washington & 14 & 27 & 1.7 & 3 & 6 \\
\hline Washington & 15 & 75 & 0.2 & 9 & 18 \\
\hline Washington & 16 & 23 & 0.2 & 8 & 17 \\
\hline Washington & 17 & 56 & 2.1 & 2 & 5 \\
\hline Washington & 18 & 108 & 0.3 & 6 & 14 \\
\hline
\end{tabular}

Another section that is relatively short but ranked high was the viewing window of the Bradford Island fishway (section $5 ; 2.1 \mathrm{kcal} \mathrm{kg}^{-1} \mathrm{~m}^{-1}$ ). It is interesting to compare this section to the viewing window section of the Washington shore fishway $\left(0.2 \mathrm{kcal} \mathrm{kg}^{-1} \mathrm{~m}^{-1}\right)$ where energy use was $\sim 10$ times lower.

Similar to the swimming speed results, the amount of energy use per unit length was fairly similar between the vertical slot fishways in the Bradford Island $\left(1.6 \mathrm{kcal} \mathrm{kg}^{-1} \mathrm{~m}^{-1}\right)$ and Washington shore fishways $\left(2.1 \mathrm{kcal} \mathrm{kg}^{-1} \mathrm{~m}^{-1}\right)$. Also, the rankings were very similar to those seen among the swimming speed data, remaining among the most energetically costly. 
Many fishway sections have similar designs, for example sections 2, 3, 5, 9, and 11 have weirs that are $5 \mathrm{~m}$ apart with a $0.3 \mathrm{~m}$ rise between the weirs. Several of these sections have very similar energy use per unit length. Fish passing the A and B branches of the Bradford Island fishway used 0.9 and $0.8 \mathrm{kcal}$ $\mathrm{kg}^{-1} \mathrm{~m}^{-1}$ respectively; and fish passing section 5 in the Bradford Island fishway, section 9 in the Cascade fishway, and section 11 in the Washington shore fishway used 1.4, 1.3, and $1.5 \mathrm{kcal} \mathrm{kg}^{-1} \mathrm{~m}^{-1}$, respectively.

By combining the ranking for energy use rates and time spent in an area, a meaningful comparison may be made among areas relative to the difficulty of fish passage (Table 3.14). If the ranking of a fishway section for energy use rate is added to the ranking for amount of time spent in that section (see Table 3.14), it can be seen that passage of the Cascade fishway not only takes a relatively long period of time, but the time spent in those areas is relatively energetically costly. Two lower sections of the Washington shore fishway (sections 11 and 12), the A branch of the Bradford Island fishway and the vertical slot weirs of the Washington Shore fishway lead the list in areas that are more energetically costly than other sections. However, there was very little difference in the rankings of a large number of fishway sections.

Table 3.14. Total Energy Use Rates and Number of Hours Spent in Different Fishway Sections by Spring Chinook Salmon Passing Bonneville Dam, April - June 2001. Ranks of energy use rates and time spent in areas are also shown $(1=$ highest $)$ among all fishway sections throughout the dam. Ranks of energy use and hours spent in areas are summed and presented as a cumulative score. These scores are ranked from lowest ( $1=$ highest combined rank of energy use rate and time). Fishway section numbers correspond to Figures 1.5, 2.2, 2.3.

\begin{tabular}{|l|c|c|c|c|c|c|c|c||}
\hline \multicolumn{1}{|c|}{ Fishway } & Section & $\mathrm{N}$ & $\begin{array}{c}\text { Total Energy Use } \\
\text { Rate }\left(\mathrm{kcal} \mathrm{kg}^{-1} \mathrm{~h}^{-1}\right)\end{array}$ & $\begin{array}{c}\text { Ranks } \\
\text { Among }\end{array}$ & Hours & $\begin{array}{c}\text { Ranks } \\
\text { Among }\end{array}$ & $\begin{array}{c}\text { Cumulative } \\
\text { Scores }\end{array}$ & $\begin{array}{c}\text { Rank of } \\
\text { Cum. Scores }\end{array}$ \\
\hline Bradford & 1 & 6 & 1.83 & 13 & 0.09 & 16 & 29 & 10 \\
\hline Bradford & 2 & 15 & 2.04 & 12 & 0.92 & 4 & 16 & 5 \\
\hline Bradford & 3 & 14 & 1.67 & 14 & 0.97 & 3 & 17 & 6 \\
\hline Bradford & 4 & 19 & 2.91 & 2 & 0.16 & 15 & 17 & 6 \\
\hline Bradford & 5 & 26 & 2.42 & 10 & 0.50 & 8 & 18 & 7 \\
\hline Bradford & 6 & 14 & 1.60 & 15 & 0.41 & 9 & 24 & 9 \\
\hline Bradford & 7 & 34 & 2.65 & 7 & 0.33 & 12 & 19 & 8 \\
\hline Cascade & 8 & 7 & 3.42 & 1 & 0.56 & 7 & 8 & 2 \\
\hline Cascade & 9 & 8 & 2.69 & 5 & 1.89 & 1 & 6 & 1 \\
\hline Washington & 10 & 30 & 2.77 & 4 & 0.25 & 13 & 17 & 6 \\
\hline Washington & 11 & 30 & 2.52 & 9 & 0.77 & 5 & 14 & 4 \\
\hline Washington & 12 & 5 & 2.53 & 8 & 1.09 & 2 & 10 & 3 \\
\hline Washington & 13 & 9 & 2.05 & 11 & 0.58 & 6 & 17 & 6 \\
\hline Washington & 14 & 36 & 1.32 & 18 & 0.34 & 11 & 29 & 10 \\
\hline Washington & 15 & 18 & 1.54 & 16 & 0.06 & 17 & 33 & 11 \\
\hline Washington & 16 & 7 & 1.51 & 17 & 0.05 & 18 & 35 & 12 \\
\hline Washington & 17 & 34 & 2.68 & 6 & 0.38 & 10 & 16 & 5 \\
\hline Washington & 18 & 25 & 2.90 & 3 & 0.19 & 14 & 17 & 6 \\
\hline \hline
\end{tabular}




\subsubsection{Variables Influencing Activity in Fishways}

\subsection{Diel Period}

Swimming speeds of spring chinook salmon passing fishways were 30\% (and significantly) higher during the day (mean 1.12 $\mathrm{BL} \mathrm{s}^{-1}$; Figure 3.27) than during the night (mean $0.86 \mathrm{BL} \mathrm{s}^{-1}$ ). Energy use rates were also significantly higher during the day than during the night with the difference being largest in anaerobic energy use (Figure 3.28). Anaerobic energy use rates were 75\% (and significantly) higher during the day $\left(1.1 \mathrm{kcal} \mathrm{kg}^{-1} \mathrm{~h}^{-1}\right)$ than during the night $\left(0.63 \mathrm{kcal} \mathrm{kg}^{-1} \mathrm{~h}^{-1}\right)$. This indicates that the amount of burst swimming decreased dramatically at night. The aerobic and total (aerobic and anaerobic combined) energy use rates were also significantly higher during the day than at night (32\% and 50\% higher respectively).
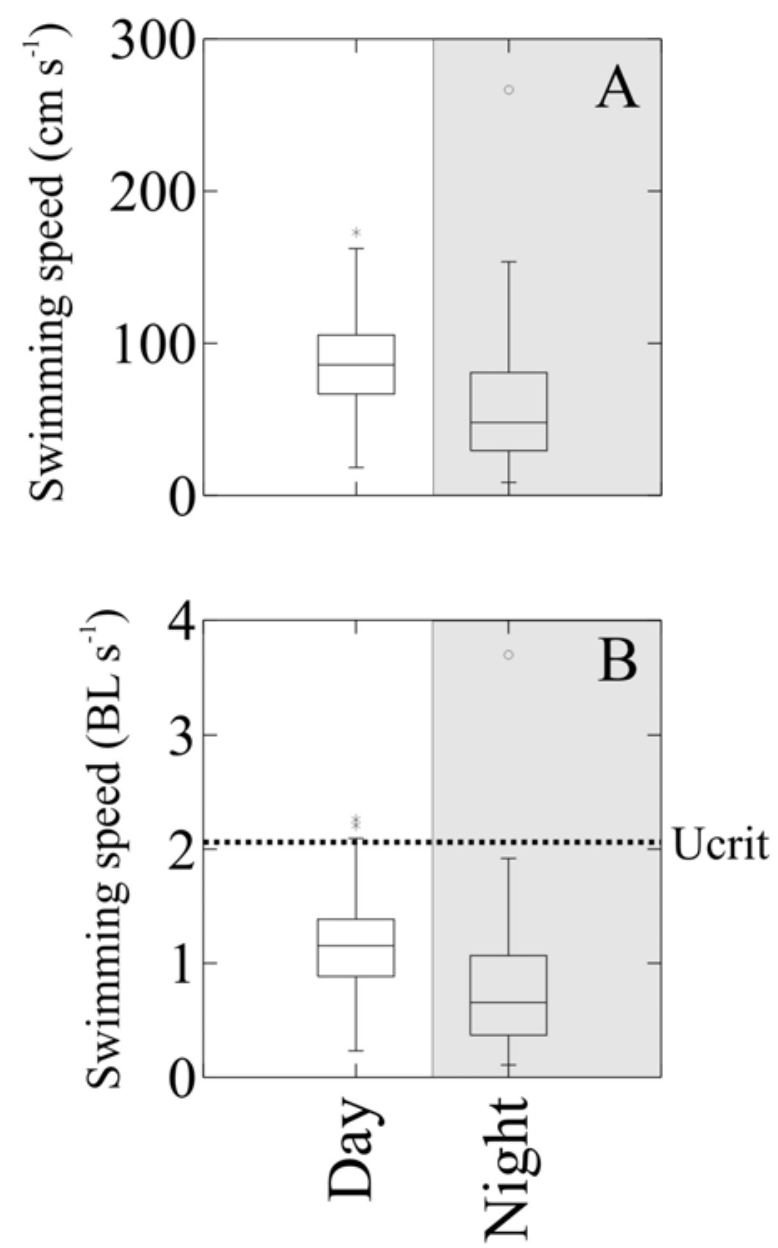

Figure 3.27. Box Plots of Swimming Speeds (in $\mathrm{cm} \mathrm{s}^{-1}$ in panel A and in $B L \mathrm{~s}^{-1}$ in panel B) of Spring Chinook Salmon in Fishways during Day and Night as They Passed Bonneville Dam, April - June, 2001. Swimming speeds are related to critical swimming speed in panel B. Boxes indicate the $25^{\text {th }}$ and $75^{\text {th }}$ percentile of data; line inside box is median. Whiskers indicate the $95 \%$ confidence intervals for the data, asterisks are outliers. 


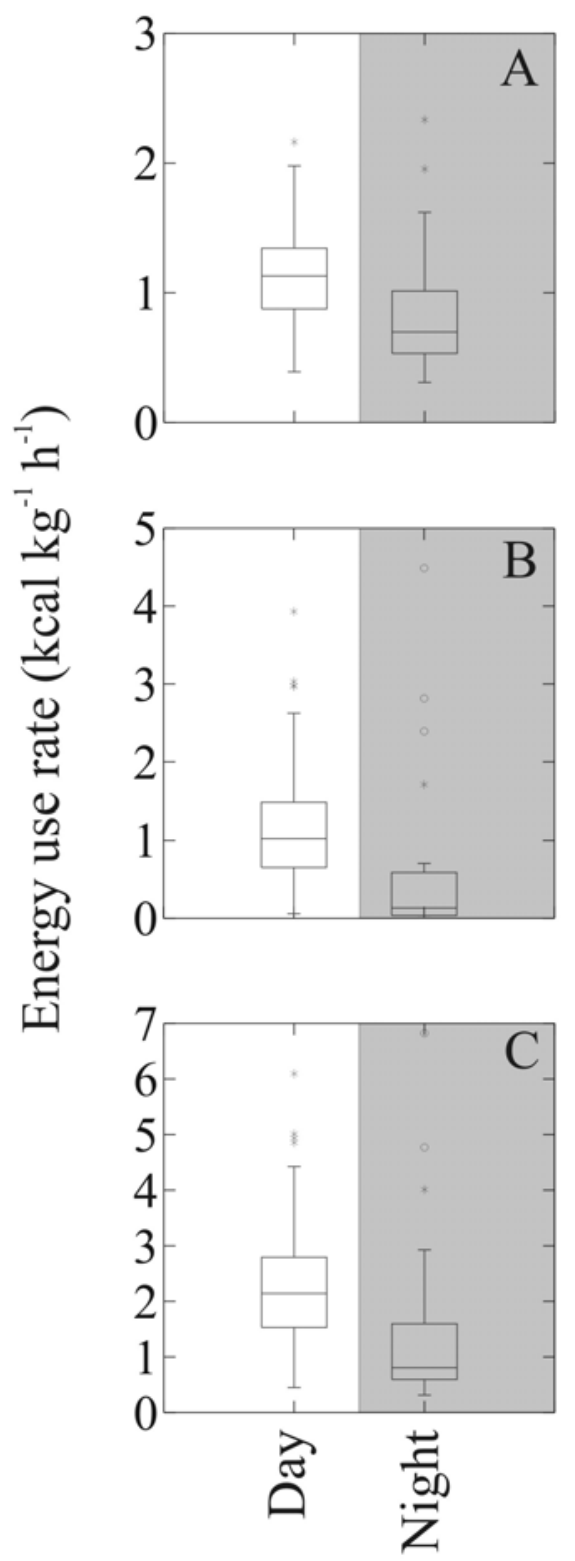

Figure 3.28. Box Plots of Energy Use Rates of Spring Chinook Salmon in Fishways during Day and Night as They Passed Bonneville Dam, April - June, 2001. Aerobic energy use rates are shown in panel A, anaerobic rates in panel B, and total rates in panel C. Boxes indicate the $25^{\text {th }}$ and $75^{\text {th }}$ percentile of data; line in box shows median. Whiskers indicate the $95 \%$ confidence intervals for the data; asterisks are outliers.

\subsection{Shad and Water Temperature}

It is difficult to determine what the relationship is between the numbers of shad in the fishway and the swimming activity and energy use of spring chinook salmon. These relationships are confounded by the relationship between both shad abundance and fish behavior with water temperature. Although there was a significant, weak positive relationship between both swimming speed $\left(\mathrm{R}^{2}=0.15\right)$ and total energy use rates $\left(\mathrm{R}^{2}=0.13\right)$ and the number of shad passing fishways (Figure 3.29), there are stronger, and also significant, relationships between water temperature and these variables (fish swimming speeds, energy 
use rates, and shad abundance; Figure 3.30). The relationship between water temperature and the number of shad in fishways is stronger $\left(\mathrm{R}^{2}=0.42\right)$ than both the relationship between swimming speed and water temperature $\left(R^{2}=0.26\right)$ and the relationship between total energy use rates and water temperature $\left(R^{2}=\right.$ 0.24 ; Figure 3.30).
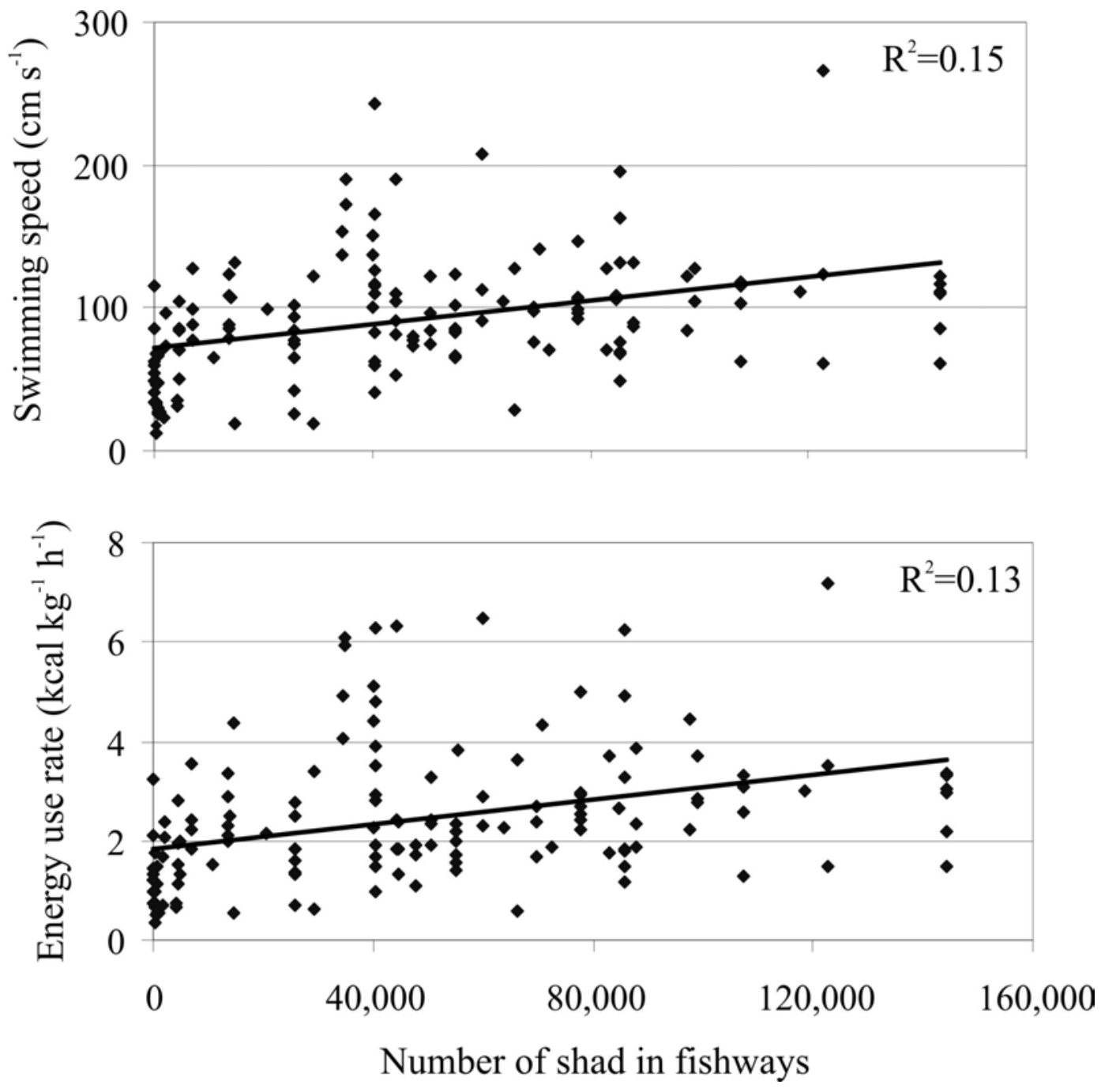

Figure 3.29. Plots of Swimming Speeds (Panel A) and Total (aerobic and anaerobic combined) Energy Use Rates (Panel B) of Migrating Spring Chinook Salmon in Fishways and the Number of Shad in Fishways at Bonneville Dam, April - June, 2001. 

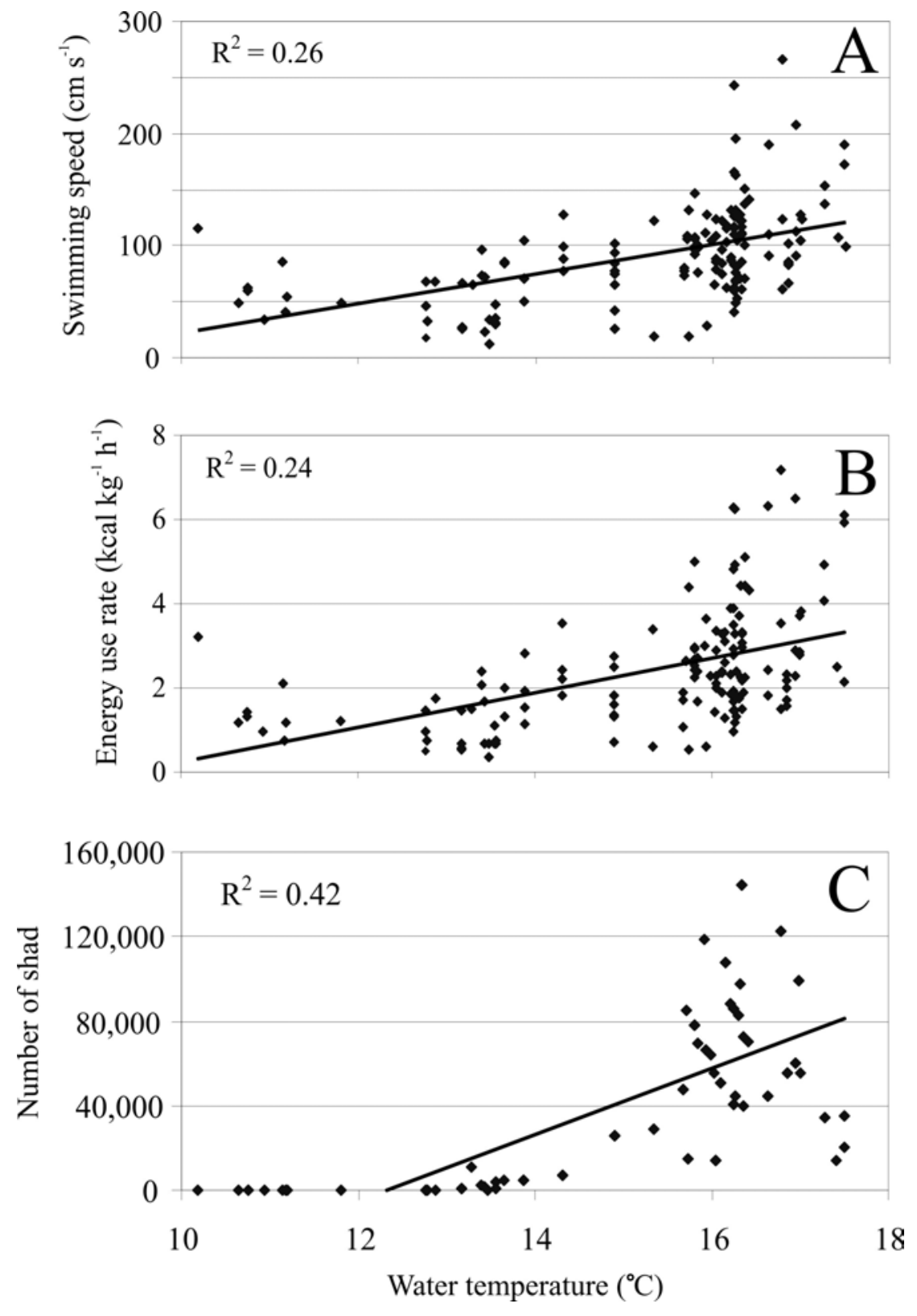

Figure 3.30. Plots of Swimming Speeds (Panel A), Total (aerobic and anaerobic combined) Energy Use Rates of Migrating Spring Chinook Salmon in Fishways (Panel B) and Number of Shad in Fishways (Panel C) and Water Temperature at Bonneville Dam, April - June, 2001. 


\subsection{Discussion}

\subsection{Laboratory Studies}

Our results indicate that the rate of oxygen consumption and red and white muscle activity in adult spring chinook salmon were strongly correlated with swimming speed over a range of fish sizes and at three different temperatures. Active oxygen consumption increased linearly with swim speed before leveling off at speeds at or above Ucrit. This pattern was similar at each water temperature and indicates that fish were approaching their maximal aerobic oxygen consumption at higher swim speeds.

Our estimates of active oxygen consumption of spring chinook salmon compare favorably with those of other large salmonids swum at similar speeds and temperatures (see Geist et al. 2000). At most swim speeds, oxygen consumption was lowest at $8{ }^{\circ} \mathrm{C}$, highest at $17^{\circ} \mathrm{C}$, and intermediate at $12.5^{\circ} \mathrm{C}$, which corresponds to the general model of a positive relation between metabolic rate and temperature in poikilotherms (Schmidt-Nielsen 1990).

In our modeling of the relation between $\mathrm{VO}_{2}$ and swim speed, temperature- but not laboratory, sex, or size - was the only factor that influenced this relation. Although the differences between the intercepts and linear slopes of the models at 8,12 , and $17.5^{\circ} \mathrm{C}$ were minor, there was a strong trend of increased oxygen consumption at increased water temperatures, which probably reflects some underlying biological significance. Thus, for predictive purposes, we chose a polynomial regression model incorporating temperature that had common intercepts and linear slopes for temperature and common slopes for the first- through third-order polynomials for swim speed. Using $\mathrm{VO}_{2}$-swim speed models based on temperature and independent of factors such as sex or size should be a powerful and biologically relevant way of estimating the energy use of fish in the wild.

Our estimates of Ucrit for adult spring chinook salmon indicate that these fish are strong swimmers and the Ucrit represents an important measure of swimming performance relevant to estimating the energy use of fish in the wild. Although Ucrit may depend on several biotic and abiotic factors (for a review see Hammer 1995), it is thought to be the swimming velocity where maximum oxygen uptake occurs and thus represents an important threshold between aerobic and anaerobic metabolism.

Our data on $\mathrm{VO}_{2}$, EMG activity, and blood chemistries (unpublished physiology data) indicate that at speeds approaching Ucrit, there was an increasing contribution of anaerobic metabolism to the swimming performance of spring chinook salmon. Specifically, anaerobiosis at higher swim speeds was evidenced in our results by 1) the leveling off of $\mathrm{VO}_{2} ; 2$ ) the leveling off of red muscle activity; 3) the increase in white muscle activity; and 4) the appearance of lactic acid in the bloodstream at the time of fatigue (data not shown). Thus, the Ucrit represents velocities that fish have difficulty swimming against for moderate or long periods of time and that can have substantial energetic costs associated with them.

Recent evidence by Hinch and Bratty (2000) indicated that passage success of sockeye salmon migrating through the notoriously difficult Hell's Gate reach on the Fraser River was dependent on the duration of time fish spent swimming at speeds at or greater than Ucrit. A knowledge of when and how long fish are swimming at speeds near Ucrit will clearly be important to estimating the energy use of fish in the wild.

Within the population of spring chinook salmon we tested, EMG activity in the red muscle was strongly and positively correlated with swim speed, a finding consistent with other studies on different species (McKinley and Power 1992; Booth et al. 1997; Thorstad et al. 2000; Geist et al. 2002). In 
contrast, EMG activity in the white muscle was relatively low at speeds below Ucrit and increased in all individuals as swim speeds approached or surpassed Ucrit. These results indicate that swimming at speeds below Ucrit is mostly powered by red muscle and swimming at speeds near or beyond Ucrit requires an increasing contribution of white muscle fibers. These conclusions conform well to the commonly reported function and physiology of red and white muscle fibers in fish (see Webb 1993 for a review). When combined with the oxygen consumption-swim speed relations, electromyogram telemetry has considerable potential for estimating the metabolic rates and swimming activity of fish in the wild. This conclusion is consistent with EMG studies conducted on other species (Kaseloo et al. 1992; McKinley and Power 1992; Demers et al. 1996; Hinch et al. 1996).

Using a hockey stick modeling approach, we determined that the convergence point at which red muscle EMGs began to decrease and white muscle EMGs began to increase in our fish was approximately $80 \%$ of the Ucrit ( $95 \%$ confidence interval, $73 \%$ to $88 \%$ Ucrit). This finding is very consistent with most studies of muscle electromyography (Hudson 1973; Bone et al. 1978; Brill and Dizon 1979; Rome et al. 1985; Beddow and McKinley 1999). The implication of this could be significant in estimating total energy used during upstream migration. For example, Burgetz et al. (1998) expressed the anaerobic metabolism as a percentage of the rate of oxygen consumption at a given speed, or an anaerobic tax. As the swimming speed increased from $70 \%$ to $100 \%$ of the Ucrit, the anaerobic tax increased such that anaerobic energy used at $70 \%, 80 \%$, and $100 \%$ of the Ucrit would be an additional $65 \%, 69.2 \%$, and $205.0 \%$ of the aerobic (oxygen consumption) energy use. Our results suggest that future modeling of total energy of adult spring chinook salmon migrating up the Columbia River must incorporate anaerobic metabolism at swimming speeds greater than approximately $80 \%$ of the Ucrit.

In summary, we have documented strong and consistent relations between oxygen consumption, electromyogram activity, and swim speed in adult spring chinook salmon. These relations will serve as the foundation for estimating the metabolic costs of upstream migration of fish in the wild. Such information will help determine the energetic costs associated with activities like fallback and delay at dams and whether excessive energy use is a problem for adult salmonids migrating in today's altered ecosystem. Ultimately, we hope to better define the relation between energy use and reproductive success in these fish. Physiological telemetry appears to be a useful tool to accomplish this goal.

\subsection{Field Studies}

\subsubsection{Swim Speed and Energy Use in the Tailraces, Fishways, and Forebays of Bonneville Dam}

This study showed that adult spring chinook salmon that passed Bonneville Dam in 2001 spent the most time, swam hardest, and used the most energy in the tailrace areas as compared to fishways or forebays. Of all energy used during dam passage, $81 \%$ was used in the tailraces.

Fish behavior during passage of the fishways and forebays was similar in several aspects. Neither swimming speeds or their correlate, energy use rates, differed between these two areas. However, as would be expected in an area where burst swimming occurs frequently, the differences between anaerobic energy rates approached significance between fishways and forebays, with fishway rates appearing to be higher than forebay rates. The main difference between fishways and forebays was that it took much longer (7.14 times longer) for fish to pass fishways than forebays. Despite having similar energy use rates, spending more time in fishways led to a greater use of energy, thus fishways were the second most energetically costly portion using $18 \%$ of total energy (compared to $1.5 \%$ used in the forebays). 
To apply these energy use data to the population of spring chinook salmon passing Bonneville Dam, results for the median fish have been presented. The median is presented since data are not normally distributed. Most fish exhibited energy use on the lower end of the scale; however, another segment of fish used a much larger amount of energy (Figure 3.9). The median fish took 26.8 hours to pass Bonneville Dam and expended $60.1 \mathrm{kcal} \mathrm{kg}^{-1}$. Since the average weight of fish is $6 \mathrm{~kg}$, a representative fish would use approximately $361 \mathrm{kcal}$ to pass Bonneville Dam. However, this median energy use does not reflect the energy used by a portion of the population. For example, $\sim 8 \%$ of the spring chinook salmon tracked in our study used more than the median (i.e., $361 \mathrm{kcal}$ ) just to pass the tailraces of Bonneville Dam. As this use of energy to pass the dam increases, the risk of prespawning mortality also increases.

There was no difference in either the swimming speeds or the energy use rates among the three forebays. It appears that the migrating spring chinook salmon sampled during this low-spill year were able to avoid high-velocity areas and maintain a rather uniform swimming behavior, avoiding fallback. This may not hold true, however, during a more normal year with higher water discharge when spill would be higher.

Unlike forebays, there were differences in behavior among tailraces. The only difference was between the tailrace of Powerhouse 2 and the spillway tailrace, with swimming speeds and energy use rates being higher in the tailrace of Powerhouse 2. It may be expected that this behavior would be present since the daily average discharge through Powerhouse 2 was higher than through Powerhouse 1 or the spillway (Figure 1.4). In fact, there was very little discharge over the spillway for a majority of the study period. However, there was also no significant difference between swimming speeds and energy use rates between the tailraces of the two powerhouses, despite the much higher water discharge through Powerhouse 2.

Discharges can vary drastically at Bonneville Dam (Figure 1.4) through the powerhouse or over the spillway with flow rates changing gradually or even stopping abruptly. Despite this large variability in dam operations, there was no relationship between the water discharge in the tailraces and the swimming speeds or energetic use rates of the fish. However, in a normal water year (with higher discharge), results may differ.

Fish exhibited varied behavior within tailraces. Periods of low energy use rates and high energy use were seen when discharge was both high and low (Figure 3.16). Thus, fish swimming speeds appear at least partially independent of discharge in tailraces. Fish activity is likely associated with water velocity on a smaller scale, whereby fish are likely resting in low-velocity areas between attempts at finding fishway entrances. Even when a tailrace has low discharge, fish may swim through low-velocity areas at a high rate of speed. Also, in an attempt to attract salmon, water velocities at fishway entrances are high during both periods of high and low discharge through the powerhouses.

The aerobic energy use rates of migrating spring chinook salmon were higher during the day than at night in tailraces of Bonneville Dam. This is consistent with other studies, which show that activity in fishways decreases during the night. For example, some researchers have found that relatively few migrating fish (e.g., Atlantic salmon, Salmo salar, and brown trout, Salmo trutta) ascend fish ladders at dams or attempt to pass waterfalls during the night (Gowans et al. 1999). Sonic tracking of three fall chinook salmon in the Bonneville pool showed that fish either slowed their pace or stopped moving as it grew dark (Johnson 1960). Similarly, migrations of chum salmon (O. keta) migrating in coastal waters have been observed swimming slower at night (between 21:00 and 03:00) than during the day (09:00 and 15:00; Tanaka et al. 2001). 
No relationship was found between the sex of the fish and swimming speeds or energy use rates for the spring chinook salmon as they passed Bonneville Dam. This is contrary to the findings of Hinch and Rand (1998) who suggest that female sockeye salmon (O. nerka) migrating in the Fraser and Nechako rivers generally swam slower and used less energy per unit distance than males. They suggest that female sockeye salmon were more energetically efficient despite generally having the same sizes and shapes (i.e., identical length-mass relationships); they suggest, however, that males may have more drag due to the development of a humped back and kype.

This is the first study examining the energetics of salmon passing a hydroelectric dam. Consequently, comparative data at hydroelectric facilities do not exist. However, there are some data sets pertaining to migration in free-flowing rivers that can be used as a general comparison. When compared to energy use rates estimated from proximate analysis studies (reviewed by Brett 1995, Table 4.1), our values for spring chinook salmon passing Bonneville Dam were generally higher. The rates of energy use we found in the fishways $\left(2.22 \mathrm{kcal} \mathrm{kg}^{-1} \mathrm{~h}^{-1}\right)$ and tailraces $\left(2.80 \mathrm{kcal} \mathrm{kg}^{-1} \mathrm{~h}^{-1}\right)$ are higher than any energy use rate estimated for male salmon of several species mentioned in Brett (1995). Because females allocate large amounts of energy to developing the gonads during migration and males complete most of their maturation in the marine environment (Brett 1995), our results - which represent the metabolic cost of swimming only more accurately reflect the energy use of males than of females. The rates collected by proximate analysis, however, were for salmon migrating in free-flowing rivers (without dams to pass).

The rates in the forebays of Bonneville Dam $\left(1.73 \mathrm{kcal} \mathrm{kg}^{-1} \mathrm{~h}^{-1}\right)$ are lower than those estimated for sockeye salmon $\left(1.84 \mathrm{kcal} \mathrm{kg}^{-1} \mathrm{~h}^{-1}\right)$ and closer to rates seen for several other species in free-flowing rivers estimated by proximate analysis (Table 4.1). The rates of energy use in the forebay area are also similar to those found by Rand and Hinch (1998) for sockeye salmon migrating in the Fraser River, British Columbia. Rand and Hinch (1998) used swimming speeds of adult sockeye salmon estimated from EMG radio telemetry (reported by Hinch and Rand 1998) to estimate the energetic costs of spawning migrations. They estimated that the costs of spawning migrations for sockeye salmon varied between approximately 1.46 and $5.42 \mathrm{kcal} \mathrm{kg}^{-1} \mathrm{~h}^{-1}$ in certain river sections (converted from their estimate of $\sim 5$ to $18 \mathrm{~W} \mathrm{~d}^{-1}$ for fish with a mean weight of $2.88 \mathrm{~kg}$ ). Difficult passage areas were on the higher end of this range while other areas were similar to rates exhibited by spring chinook salmon passing Bonneville Dam, ranging from 1.45 to $3.0 \mathrm{kcal} \mathrm{kg}^{-1} \mathrm{~h}^{-1}$.

The energy use values estimated by Rand and Hinch (1998) agree more with estimates of energy use at Bonneville Dam than many of the values obtained by proximate analysis studies. This may be due to the fact that energy use values collected in proximate analysis studies may be biased toward lower values. Proximate analysis studies estimate the energy contained in the bodies of salmon at the start and end of migrations and sometimes at several points along the migration. However, mortality of salmon occurs along the migration, and the fittest salmon reach the spawning grounds. Since fish collected at the end of the migration reflect the fittest individuals in the population, having either higher energy reserves at the start of migrations, or using energy more efficiently than the fish that die along the migration, estimates of energy use via proximate analysis are likely biased toward low energy use values (Peter Rand, personal communication, July 2002, Vancouver, BC). 
Table 4.1. Energy Use Rates of Spring Chinook Salmon Passing Bonneville Dam, April - June 2001. For comparison, energy use rates during spawning migration of male salmon of several species are shown (from Brett 1995).

\begin{tabular}{|c|c|c|c|}
\hline Area & $\begin{array}{c}\text { Aerobic } \\
\mathrm{kcal} \mathrm{kg}^{-1} \mathrm{~h}^{-1}\end{array}$ & $\begin{array}{c}\text { Anaerobic } \\
\mathrm{kcal} \mathrm{kg}^{-1} \mathrm{~h}^{-1}\end{array}$ & $\begin{array}{c}\text { Total } \\
\text { kcal kg }^{-1} \mathrm{~h}^{-1}\end{array}$ \\
\hline Tailraces & 1.27 & 1.53 & 2.80 \\
\hline Fishways & 1.11 & 1.11 & 2.22 \\
\hline Forebays & 1.00 & 0.73 & 1.73 \\
\hline \multicolumn{4}{|c|}{ Other Species } \\
\hline \multicolumn{3}{|c|}{ chinook (Greene 1926) } & 1.38 \\
\hline \multicolumn{3}{|c|}{ chum (Pentegoff et al. 1928) } & 1.13 \\
\hline \multicolumn{3}{|c|}{ pink (Williams et al. 1986) } & 0.93 \\
\hline \multicolumn{3}{|c|}{ sockeye (Newman \& Collins 1967) } & 1.14 \\
\hline \multicolumn{3}{|c|}{ sockeye (Gilhousen 1980) } & $0.88-1.42$ \\
\hline \multicolumn{3}{|c|}{ sockeye (Idler \& Clemens 1959) } & 1.84 \\
\hline
\end{tabular}

\subsubsection{Swim Speeds and Energy Use among Sections of the Fishways of Bonneville Dam}

\subsubsection{Swimming Speed and Energetics}

Although there was no significant difference in swimming speeds or energy use rates among the three fishways, the sample size of fish in the Cascade Island fishway was low $(\mathrm{N}=8)$. This was likely associated with the relatively little flow over the spillway during the study period. Fish only entered the Cascade Island fishway while there was discharge over the tailrace. Examining swimming behavior of fish in this area when there is spill would likely increase use of the Cascade Island fishway and improve the quantity and quality of data in this area.

It is not unusual that mean swimming speeds and energy use were similar among the fishways. These fishways are very similar in design. The pool and weir fishways that dominate all fishways have similar size, spacing, and gradient. This will be discussed further in the section discussing individual fishway sections.

The amount of time that it took fish to pass fishways varied with the fishway they passed. However, since swimming speeds did not differ among the three fishways, other factors are involved. One of these factors is that the length of these fishways varies. A fish passing the Bradford fishway through the A branch would only need to travel less than $400 \mathrm{~m}$ (Table 3.13) to exit the fishway. However, a fish passing the Washington shore fishway may travel over $800 \mathrm{~m}$. Fish passing the Cascade fishway must pass through $\sim 300 \mathrm{~m}$ of fishway in the Cascade fishway proper, then pass through the UMT channel (156 m long) and then another $\sim 300 \mathrm{~m}$ of the upper Washington shore fishway. These longer distances are factors in the differences in travel time and energy expenditure among fishways. 


\subsubsection{Fallout}

The percentage of spring chinook salmon tracked during this study that fell out of fishways was less (32\%) than observed at other dams in the Columbia Basin. A study of chinook salmon that fell out of Snake River Fishways in the summer of 1993 found 57\% fell out at Ice Harbor Dam, 65\% at Lower Monumental Dam, 58\% at Little Goose Dam, and 63\% at Lower Granite Dam (Bjornn et al. 1995). However, it must be noted that during the current study, we did not have enough equipment to monitor EMG signals from fish in the south monolith entrances to the Washington Shore or Bradford Island fishways or from the fishways at the base of the two powerhouses. Because of this, we likely underestimate the number of fallouts, and the energetic consequences of fallout.

\subsubsection{Differences among Section of Fishways}

Throughout the passage of different fishway areas, mean swimming speeds were well under critical swimming speed. This indicates that fish did not appear to have excessive difficulty passing any of the fishway sections. However, one section that did stand out was the exit to the Washington shore fishway. Although this section has relatively low water velocities and does not contain any weirs for fish to pass, the ranking of swimming speed in this section is very high. Also, manual trackers noted that fish appeared to be swimming very quickly at the lower end of this section, near the exit of the vertical slot weirs. Further examination of salmon behavior in this area is recommended.

Among all areas of fishways, although swimming speeds and energy use rates varied, no serious hindrance to passage was obvious. The reason for elevated swimming speeds or energy use rates can differ, both of these rates were elevated in the junction pool of the Bradford Island Fishway. However, this area does not likely pose an area of difficult passage. Instead, the junction pool of the Bradford Island fishway is traveled through at a speed (a mean of $109 \mathrm{~cm} \mathrm{~s}^{-1}$ ) that is near the optimum cruising speed for salmon ( $1 \mathrm{Bl} \mathrm{s}^{-1}$; Webb 1995) and is likely moved through quickly because it is low velocity, and there are no weirs within it.

However, when swimming speed and energy use rates are elevated for long periods of time in an area, it may be worth doing further examination of fish behavior there to ease and reduce the energy consumption of passage. When the ranks of energy use rates and time spent in an area were combined (Table 3.14), the Cascade Island fishway stands out as the most energetically costly route for dam passage. Not only do fish have to travel a longer distance than if passing the other two fishways, and fish spend a relatively long period of time there, but energy use rates are relatively high. One possible source of delay in this area is the presence of bubbles in the entrances to some fishways. There are problems with bubbles in the diffusers in both the Bradford Island and Cascade Island fishways (Tammy Mackey, Personal communication September 12, 2002).

Another possible source of delay in fishways is the presence of sharp bends or corners. Although several sections have very similar design (sections 2, 3, 5, 9, and 11), the energy used per m varied among some of these sections. Part of this may be due to bends, corners, or other structures in these fishway sections. Spring chinook salmon passing the A and B branches of the Bradford Island fishway had very similar ( 0.9 and $\left.0.8 \mathrm{kcal} \mathrm{kg}^{-1} \mathrm{~m}^{-1}\right)$ and lower energy use rates than fish passing section 9 or 11 (where use was 1.3 and $1.5 \mathrm{kcal} \mathrm{kg}^{-1} \mathrm{~m}^{-1}$ ). Weaver (1963) reported significantly longer passage times through corner and bend pools. Section 2 and 3 have relatively gentle bends in them, while section 9 and 11 either have a fairly sharp bend (section 9) or a corner (section 11). 


\subsubsection{Variables Influencing Activity}

\subsection{Diel period}

There was a relationship between the time of entry to fishways by spring chinook salmon and the amount of time they spent in fishways, and this relationship relates to their diel behavior. Fish that successfully passed the dam did not enter fishways after 22:00 and generally those that entered fishways without adequate time to pass before dark (or $\sim 22: 00$ ) spent the night in fishways. Also, swimming speeds and energy use rates of spring chinook salmon in fishways were lower during the night than during the day.

All of these factors indicate less activity at night and less movement through fishways at night. This decrease in movement through fishways at night has been previously documented. Bjornn et al. (1995) found that in Snake River dams, salmon temporarily discontinue upstream migration at night while in fishways. Gowans et al. (1999) found that relatively few migrating Atlantic salmon (Salmo salar) or brown trout (Salmo trutta) ascend fish ladders at dams or attempt to pass waterfalls during the night.

However, if artificial light is present, the behavior of migrating salmon increases during the night. Brett and MacKinnon (1954) found that, when artificial light was present, the passage of pink salmon $(O$. gorbuscha) through fishways was higher at night. Collins et al. (1962) also found that fish continued to move through an endless fishway 24 hours a day if artificial light was present. Even entry into fishways by chinook, sockeye, and coho salmon and steelhead increases during the night when artificial light is present (Gauley 1967).

\subsection{Shad and Temperature}

The fishways on the Columbia River dams were not initially designed for shad passage, consequently during shad runs, which coincided with salmon runs, the accumulation and eventual death of shad resulted in the blockage of salmon passage (Bates 2000). Part of the reason shad were delayed at Columbia river dams was that, unlike Pacific salmon, shad would not pass through the orifices in the weirs of fish ladders and several sections of fishways (such as the flow control sections) had orifices with no surface overflow (Bates 2000).

We examined the relationships between the number of shad passing Bonneville Dam and the swimming speed and energy use rates of migrating spring chinook salmon. Unfortunately, water temperature was a correlate to both shad numbers and the energy use rates of migrating salmon. Due to this, no conclusive statements can be made concerning the interactions of shad and migrating salmon. To determine whether shad influence the energy use of fish in the fishway, experiments would be needed to examine the energy use of salmon when the water temperatures were constant and shad abundance could be varied. 


\subsection{Management Implications and Recommendations}

The higher swimming speeds and energy use rates we found in the Bonneville Dam tailraces are likely associated with generally higher water velocities in the tailraces than other areas and with problems finding the openings of fishways. The high energy use rates in tailraces may be partially due to a lack of resting areas along the approach to the fishway entrances. In comparison, the fishways themselves are designed to allow fish to rest at each step and between other high-velocity areas.

Spring chinook salmon used burst swimming more in the tailraces than in other parts of the dam. This is indicated by the higher anaerobic energy use rates in the tailraces than in the fishways or forebays. Burst swimming is used by salmon to pass high velocity areas (Webb 1995). However, fish are unable to sustain burst swimming speeds for long periods of time. Brett (1995) states that jumps or bursts of swimming at falls or obstacles in streams probably do not exceed 20 to 30 seconds. Similarly, Webb (1995) states that burst swimming can be maintained less than about 30 seconds. Brown and Geist (2002) found fall chinook salmon attempting to pass waterfalls used burst swimming for periods with a mean of only 20 seconds at a time. Thus, fish may use excess energy and be delayed at dams if water velocities exceed critical swimming speeds for long distances without areas to rest. Fish can spend long periods of time in tailraces searching for entrances to fishways. When attempting to pass hydroelectric dams, chinook salmon can make up to 30 approaches before successfully entering fishways (Bjornn et al. 1995).

Adding structures in tailraces that allow fish to rest as they approach the dam may decrease energy use and delay. Also, these structures could be placed in a way that guide fish toward the entrances to fish ladders.

Additional use of EMG telemetry would be helpful to examine the behavior of fish in the highvelocity waters near the powerhouses and spillway, especially near the entrances to the fishways. We suggest experimenting with structures placed in the tailraces to allow resting and guidance along the path to fishway entrances.

Also, since 2001 was a dry year, and there was very little spill, few fish fell back over the spillway. An additional year of study would be helpful to determine the relationships between forebay flow characteristics and the behavior associated with fallback under more typical flow conditions.

Among all fishway areas, Cascade Island fishway appears to be the most energetically costly. Also, section 12 of the Washington shore fishway appears costly. It appears from our data that there is an energetic cost associated with diverting fish from the Washington shore ladder to the adult facility. These costs should be compared with the benefits of the research that uses the adult facility.

Further research in fishways should concentrate on fish behavior in the exit of the Washington shore fishway near the vertical slot weirs. Also, an evaluation of the relationship between bubbles in the fishway entrances and delays of passage in these areas is recommended.

Although the Cascade Island fishway appears to be more energetically costly than other fishways, the number of fish sampled in this fishway was limited. Only 8 fish went through this fishway while 34 to 37 went through the other two. This is likely due to the lack of spill attracting fish to the tailrace of the spillway during the low flow year of the study. Further research in a year with more normal flows would likely improve the quantity and quality of data in this area. 
Energy used during fallouts was substantial (11.5\% to $18.8 \%$ of the amount of energy used for successful fishway passages). This percentage was highest in the Cascade Island fishway (18.8\%) where energy use rates during fallout were even higher $\left(3.67 \mathrm{kcal} \mathrm{kg}^{1} \mathrm{~h}^{1}\right)$ than energy use rates in the tailrace $\left(2.8 \mathrm{kcal} \mathrm{kg}^{1} \mathrm{~h}^{1}\right)$. If management agencies are interested, existing data on individual salmon could be examined further, possibly leading to a reduction in this behavior and a decrease in energy expenditures of passage. 


\subsection{References}

Bates, K. 2000. Fishway Guidelines for Washington State. Washington Department of Fish and Wildlife. Available at http://www.wa.gov/wdfw/hab/ahg/fishguid.pdf.

Beamish, F.W.H. 1978. "Swimming Capacity." Chapter 2 in Fish Physiology (W.H. Hoar and D.J. Randall, eds.), Volume 7. Academic Press, New York.

Beddow, T.A., and R.S. McKinley. 1999. "Importance of Electrode Positioning in Biotelemetry Studies Estimating Muscle Activity in Fish.” Journal of Fish Biology 54:819-831.

Beiningen, K.T., and W.J. Ebel. 1970. "Effects of John Day Dam on Dissolved Nitrogen Concentrations and Salmon in the Columbia River." Transactions of the American Fisheries Society 99:664-671.

Berman, C.H., and T.P. Quinn. 1991. "Behavioral Thermoregulation and Homing by Spring Chinook Salmon, Oncorhynchus tshawytscha (Walbaum), in the Yakima River". J. Fish Biol. 39: 301-312.

Bjornn, T.C., J.P. Hunt, K.R. Tolotti, P.J. Kneiry, and R.R. Ringe. 1994. Migration of Adult Chinook Salmon and Steelhead Past Dams and through Reservoirs in the Lower Snake River and into Tributaries - 1992. U.S. Army Corps of Engineers, Walla Walla, Washington.

Bjornn, T.C., J.P. Hunt, K.R. Tolotti, P.J. Keniry, and R.R. Ringe. 1995. Migration of Adult Chinook Salmon and Steelhead Past Dams and through Reservoirs in the Lower Snake River and into Tributaries - 1993. Technical Report 95-1, Idaho Cooperative Fish and Wildlife Research Unit, University of Idaho, Moscow.

Bjornn, T.C., M.L. Keefer, C.A. Peery, K.R. Tolotti, R.R. Ringe, and L.C. Stuehrenberg. 1999b. Adult Chinook and Sockeye Salmon, and Steelhead Fallback Rates at the Dalles Dam1996, 1997, and 1998. Draft Report to the U.S. Army Corps of Engineers, Portland, Oregon, and Walla Walla, Washington, and to the Bonneville Power Administration, Portland, Oregon.

Bjornn, T.C., T.S. Reischel, R.R. Ringe, K.R. Tolotti, and L.S. Stuehrenberg. 1999. Radio Telemetry Assessments of Migration Patterns and Fallbacks of Adult Salmon and Steelhead in the Forebay of Bonneville Dam, 1997-1998. Technical Report 99-1. U.S. Army Corps of Engineers, Portland, Oregon.

Bjornn, T.C., M.L. Keefer, C.A. Peery, M. A. Jepson, K.R. Tolotti, R.R. Ringe, and L.C. Stuehrenberg. 2000a. Adult Chinook and Sockeye Salmon, and Steelhead Fallback Rates at the Dalles Dam - 1996, 1997, and 1998. Report to the U.S. Army Corps of Engineers, Portland, Oregon, and Walla Walla, Washington, and to the Bonneville Power Administration, Portland, Oregon. 
Bjornn, T. C., M.L. Keefer, C.A. Peery, K.R. Tolotti, R.R. Ringe, P.J. Keniry and, L.C. Stuehrenberg. 2000b. "Migration of Adult Spring and Summer Chinook Salmon Past Columbia and Snake River Dams, Through Reservoirs and Distribution into Tributaries, 1996." Report to the U.S. Army Corps of Engineers, Portland, Oregon, and Walla Walla, Washington, and to the Bonneville Power Administration, Portland, Oregon.

Bone, Q., J. Kiceniuk, and D.R. Jones. 1978. "On the Role of the Different Fibre Types in Fish Myotomes at Intermediate Swimming Speeds." Fishery Bulletin of the US Fish and Wildlife Service 76:691-699.

Booth, R. K., R. S. McKinley, F. Økland, and M. M. Sisak. 1997. "In situ Measurement of Swimming Performance of Wild Atlantic Salmon (Salmo salar) Using Radio Transmitted Electromyogram Signals.” Aquatic Living Resources 10:213-219.

Brafield, A. E., and D. J. Solomon. 1972. "Oxy-Calorific Coefficients for Animals Respiring Nitrogenous Substrates.” Comparative Biochemistry and Physiology A, Comparative Physiology 43:837-841.

Brett, J.R. and D. MacKinnon. 1954. "Some Aspects of Olfactory Perception in Migrating Adult Coho and Spring Salmon." J. Fish. Res. Bd. Can. 11(3):310-318.

Brett, J.R. 1995. "Energetics.” In Physiological Ecology of Pacific Salmon, ed. C. Groot, L. Margolis, and W. C. Clarke. pp.3-68. UBC Press, Vancouver, British Columbia.

Brill, R.W., and A.E. Dizon. 1979. "Red and White Muscle Fibre Activity in Swimming Skipjack Tuna, Katsuwonus pelamis (L.)”. Journal of Fish Biology 15: 670-685.

Brown, R. S., and D. R. Geist. 2002. Determination of Swimming Speeds and Energetic Demands of Upriver Migrating Fall Chinook Salmon (Oncorhynchus tshawytscha) in the Klickitat River. Project Number 22063. Prepared for Bonneville Power Administration by Pacific Northwest National Laboratory.

Burgetz, I.J.; A. Rojas-Vargas; S.G. Hinch, and D.J. Randall. 1998. "Initial Recruitment of Anaerobic Metabolism during Sub-Maximal Swimming in Rainbow Trout (Oncorhynchus mykiss).” J. Exp. Biol. 201(19):2711-2721.

Cameron, J.N., and J.J. Cech. 1990. "Lactate Kinetics in Exercised Channel Catfish, Ictalurus punctatus." Physiological Zoology 63:909-920.

Campbell, P.M., T.G. Pottinger, and J.P. Sumpter. 1992. Stress Reduces the Quality of Gametes Produced by Rainbow Trout. Biology of Reproduction 47:1140-1150.

Collins, G.B., J.R. Gauley, and C.H. Elling. 1962. "Ability of Salmonids to Ascend High Fishways." Trans. Am. Fish. Soc. 91: 1-7.

Connor, A.R., C.H. Elling, E.C. Black, G.B. Collins, J.R. Gauley, and E. Trevor-Smith. 1964. "Changes in Glycogen and Lactate Levels in Migrating Salmonid Fishes Ascending 
Experimental 'Endless' Fishways.” Journal of the Fisheries Research Board of Canada 21:255-290.

Dauble, D.D., and R.P. Mueller. 2000. 'Upstream Passage Monitoring: Difficulties in Estimating Survival for Adult Chinook Salmon in the Columbia and Snake Rivers." Fisheries 25(8):24-34.

Demers, E., R. S. McKinley, A. H. Weatherly, and D. J. McQueen. 1996. Activity Patterns of Largemouth and Smallmouth Bass Determined with Electromyogram Biotelemetry. Transactions of the American Fisheries Society 125:434-439.

Driedzic, W.R., and J.W. Kiceniuk. 1976. "Blood Lactate Levels in Free-Swimming Rainbow Trout (Salmo gairdneri) Before and After Strenuous Exercise Resulting in Fatigue." Journal of the Fisheries Research Board of Canada 33:173-176.

Gauley, J. R. 1967. "Effect of Water Velocity on Passage of Salmonids in a Transportation Channel." USFWS Fishery Bulletin, 66(1):59-63.

Geist, D.R., C.S. Abernethy, S.L. Blanton, and V.I. Cullinan. 2000. “The use of electromyogram telemetry to estimate energy expenditure of adult fall chinook salmon." Transactions of the American Fisheries Society 129:126-135.

Geist, D. R., R. S. Brown, K. Lepla, and J. Chandler. 2002. "Practical application of electromyogram radiotelemetry: the suitability of applying laboratory-acquired calibration data to field data." North American Journal of Fisheries Management 22:474-479.

Gowans, A.R.D., J.D. Armstrong, and I.G. Priede. 1999. "Movements of Adult Atlantic Salmon in Relation to a Hydroelectric Dam and Fish Ladder." J. Fish Biol. 54: 713-726.

Gray, R.H. 1990. "Fish behavior and environmental assessment." Environmental Toxicology and Chemistry 9:53-67.

Greene, C.W. 1926. "The Physiology of the Spawning Migration.” Physiological Reviews 6(2): 201-241.

Groot, C., and L. Margolis, editors. 1991. Pacific Salmon Life Histories. University of British Columbia Press, Vancouver, BC.

Hammer, C. 1995. "Fatigue and exercise tests with fish." Comparative Biochemistry and Physiology 112A:1-20.

Hinch, S.G., R.E. Diewert, T.J. Lissimore, A.M. Prince, M.C. Healey, and M.A. Henderson. 1996. "Use of Electromyogram Telemetry to Assess Difficult Passage Areas for RiverMigrating Adult Sockeye Salmon." Transactions of the American Fisheries Society 125:253-260. 
Hinch, S.G., and P.S. Rand. 1998. "Swim Speeds and Energy Use of Upriver-Migrating Sockeye Salmon (Oncorhynchus nerka): Role of Local Environment and Fish Characteristics.” Can. J. Fish. Aquat. Sci. 55: 1821-1831.

Hinch, S.G., and J. Bratty. 2000. "Effects of Swim Speed and Activity Pattern on Success of Adult Sockeye Salmon Migration through an Area of Difficult Passage." Transactions of the American Fisheries Society 129:598-606.

Hudson, R.C. 1973. "On the function of the white muscles in teleosts at intermediate swimming speeds." Journal of Experimental Biology 58:509-522.

Johnson, J. H. 1960. "Sonic Tracking of Adult Salmon at Bonneville Dam, 1957.” Fishery Bulletin 176 Vol. 60: 471-484.

Kaseloo, P.A.; A.H. Weatherley, J. Lotimer, and M.D. Farina. 1992. "A Biotelemetry System Recording Fish Activity.” J. Fish Biol. 40:165-179.

Klepper, O., and Bedaux, J.J.M. 1997. "Nonlinear parameter estimation for toxicological threshold models." Ecological Modeling 102:315-324.

Liscom, K. L., G. E. Monan, L. C. Stuehrenberg, and P. J. Wilder. 1985. "Radio-tracking Studies on Adult Chinook Salmon and Steelhead Trout at Lower Columbia River Hydroelectric Dams, 1971-77.” NOAA Tech. Memo. NMFS F/NWC-81, 225 p. (Available from NMFS/NOAA Northwest Fisheries Science Center, Seattle WA)

McKinley, R.S., and G. Power. 1992. Measurement of activity and oxygen consumption for adult lake sturgeon (Acipenser fulvescens) in the wild using radio transmitted EMG signals. In Wildlife Telemetry: Remote Monitoring and Tracking of Animals (I.G. Priede and S.M. Swift, ed.) pp. 307-318. Ellis Horwood, New York.

Mendel, G. and D. Milks. 1997. "Upstream passage and spawning of fall chinook salmon in the Snake River." Chapter 1 in Upstream Passage, Spawning, and Stock Identification of Fall Chinook Salmon in the Snake River, 1992 and 1993 (H.L. Blankenship and G. Mendel, eds.) Final Report. Bonneville Power Administration, Portland, Oregon.

Mendel, G., D. Milks, R. Bugert, and K. Petersen. 1992. Upstream Passage and Spawning of Fall Chinook Salmon in the Snake River, 1991. Washington Department of Fisheries, Olympia, Washington.

Ǿkland, F., E.B. Thorstad, R.S. McKinley, B. Finstad, and R.K. Booth. 1997. "Radio transmitted electromyogram (EMG) signals as indicators of physical activity in Altlantic salmon (Salmo salar).” Journal of Fish Biology 51:476-488.

Pagnotta, A., and C.L. Milligan. 1991. "The role of blood glucose in the restoration of muscle glycogen during recovery from exhaustive exercise in rainbow trout (Oncorhynchus mykiss) and winter flounder (Pseudopleuronectes americanus)." Journal of Experimental Biology 161:489-508. 
Rakowski, C. L., and M. C. Richmond. 2000. Bonneville Project Adult Migrant Fallback Study. Letter Report. U.S. Army Portland District Corps of Engineers, Portland, Oregon.

Raleigh, R.F., W.J. Miller, and P.C. Nelson. 1986. "Habitat Suitability Index Models and Instream Flow Suitability Curves: Chinook Salmon." U.S. Fish and Wildlife Service Biological Report 82(10.122), USFWS, Washington, D.C.

Ramsey, F.L., and D.W. Schafer. 1996. The statistical Sleuth: a Course in Methods of Data Analysis. Duxbury Press, New York.

Rand, P.S, and S.G. Hinch. 1998. "Swim Speeds and Energy Use of Upriver Migrating Sockeye Salmon (Oncorhynchus nerka): Simulating Metabolic Power and Assessing Risk of Energy Depletion." Can. J. Fish. Aquat. Sci. 55: 1832-1841.

Rome, L.C. P.T. Loughna, and G. Goldspink. 1985. Temperature Acclimation: Improved Sustained Swimming Performance in Carp at Low Temperature. Science 228, 194-196.

Schmidt-Nielsen, K. 1991. Animal Physiology: Adaptation and Environment. Cambridge University Press, New York.

Smit, H., J.M. Amelink-Koutstaal, J. Vijverberg, and J.C. Von Vaupel-Klein. 1971. “Oxygen consumption and efficiency of swimming goldfish." Comparative Biochemistry and Physiology 39A:1-28.

Snelling, J.C., and 6 co-authors. 1992. Migratory Characteristics of Spring Chinook Salmon in the Willamette River. Oregon Cooperative Fishery Unit, Oregon State University, Corvallis, Oregon.

Sumerfelt, R.C., and L.S. Smith. 1990. "Anesthesia, surgery, and related techniques." In Methods for Fish Biology (C.B. Schreck and P.B. Moyle, eds.) pp. 213-273, American Fisheries Society, Bethesda, Maryland.

Swan, G. A., L. K. Timme, R. N. Iwamoto, L.C. Stuehrenberg, E. E. Hockersmith, B. L. Iverson, and B. J. Sandford. 1994. Wells Dam Radio-telemetry Study 1992. NMFS/NOAA Northwest Fisheries Science Center. Report to Douglas County PUD, East Wenatchee Washington.

Tanaka, H., Y. Takagi, and Y. Naito. 2001. "Swimming Speeds and Buoyancy Compensation of Migrating Adult Chum Salmon Oncorhynchus keta Revealed by Speed/Depth/Acceleration Data Logger.” J. Exp. Biol. 204:3895-3904.

Thorstad, E.B., F. Ǿkland, A. Koed, and R.S. McKinley. (2000). Radio-transmitted electromyogram signals as indicators of swimming speed in lake trout and brown trout. Journal of Fish Biology 57, 547-561.

Tufts, B.L., Y. Tang, K. Tufts, and R. G. Boutilier. (1991). Exhaustive exercise in wild Atlantic salmon (Salmo salar): acid-base regulation and blood gas transport. Canadian Journal of Fisheries and Aquatic Sciences 48:868-874. 
Weaver, C. 1963. "Influence of Water Velocity upon Orientation and Performance of Adult Migrating Salmonids." Fish. Bull. 63:97-121. U.S. Fish Wildl. Serv., Washington, D.C.

Webb, P.W. 1993. "Swimming." Chapter 2 in The Physiology of Fishes (D.H. Evans, ed.) Boca Raton, Florida: CRC Press.

Webb, P. W. 1995. “Locomotion.” In Physiological Ecology of Pacific Salmon, ed. C.Groot, L. Margolis, and W.C. Clarke. pp. 79-99. UBC Press, Vancouver, British Columbia.

Wood, C.M., J.D. Turner, and M.S. Graham. (1983). Why do fish die after severe exercise? Journal of Fish Biology 22:189-201. 